Claudia Barreto Kucharsky

\title{
O RELISE: \\ como se organiza esse novo gênero
}

Dissertação de Mestrado em Filologia e Língua Portuguesa

DLVC - FFLCH

USP - SP

2006 
Claudia Barreto Kucharsky

\title{
O RELISE: \\ como se organiza esse novo gênero
}

Dissertação apresentada à Faculdade de Filosofia, Letras e Ciências Humanas - FFLCH, da Universidade de Sâo Paulo, como exigência parcial para obtenção do Título de Mestre em Filologia e Lìngua Portuguesa, sob a orientação da Professora Doutora Norma Seltzer Goldstein.

Claudia Barreto Kucharsky

\author{
DLVC - FFLCH \\ USP - SP \\ 2006
}


Dissertação aprovada pela Comissão Julgadora para obtenção do Grau de Mestre em Filologia e Língua Portuguesa

Banca Examinadora:

$\operatorname{Prof}^{a} \operatorname{Dr}^{\mathrm{a}}$ Norma Seltzer Goldstein

Prof $^{a} \operatorname{Dr}^{\mathrm{a}}$ Anna Maria Marques Cintra

$\operatorname{Prof}^{a} \operatorname{Dr}^{\mathrm{a}}$ Maria Adélia Ferreira Mauro 
Ao meu filho, Lucas, que me acompanhou nesta empreitada desde a barriga e encheu de alegria todos os momentos desta dissertação. 


\section{Agradecimentos}

À CAPES (Coordenação de Aperfeiçoamento de Pessoal de Nível Superior), pela bolsa de estudo que possibilitou a realização dessa pesquisa;

À Profa $\operatorname{Dr}^{\mathrm{a}}$ Norma Seltzer Goldestein, pela paciência, confiança e orientação, e às Prof ${ }^{\text {as }} \operatorname{Dr}^{\text {as }}$ Anna Maria Marques Cintra e Maria Adélia Ferreira Mauro, pela gentileza da leitura atenta, sugestões e estímulo;

Ao meu marido, Claudio, pela compreensão e incentivo incondicional ao longo de todo o processo;

À minha família, meus pais Wilson e Maria Luiza e meu irmão Mauricio, por terem sido os primeiros a acreditar neste Mestrado. 
"A riqueza e diversidade dos gêneros discursivos é imensa, porque as possibilidades da atividade humana são inesgotáveis e porque em cada esfera da práxis existe todo um repertório de gêneros discursivos que se diferencia e cresce à medida que se desenvolve e se complexifica a própria esfera"

Mikhail Bakhtin

(Estética da Criação Verbal) 


\section{Resumo}

O presente estudo tem como objetivo descrever e caracterizar o relise - produto textual realizado pelas assessoria de imprensa para divulgação de seus clientes na mídia - como um novo gênero da esfera de produção jornalística. Optamos pelo enfoque discursivo sobre os gêneros formulado por Bakhtin: os discursos são constituídos sócio-historicamente e determinados pelos diferentes modos de produção, assim como pelas relações estabelecidas entre os interlocutores.

Para analisar esse gênero pouco conhecido do grande público, foi necessário, num primeiro momento, situar o leitor deste trabalho no universo das assessorias de imprensa, contando um pouco da história de seu surgimento e do importante papel do relise no dia-a-dia dos escritórios de comunicação.

Calcado nas teorias da corrente bakhtiniana sobre gênero e suas aplicações nos estudos de lingüistas contemporâneos, buscou-se apresentar uma conceituação detalhada dos gêneros discursivos, como apoio para a caracterização do relise, evidenciando os recursos persuasivos que permeiam os textos produzidos pelos assessores de imprensa.

A análise de cinco relises produzidos por diferentes escritórios de Al, abordando temas variados, revelou que, apesar de cada um deles focar em um público específico, o conjunto deles apresenta aspectos em comum, configurando um gênero com função comunicativa e estilo próprio.

Trazemos ainda, ao final, materías publicadas na imprensa sobre um sexto texto analisado, exemplos de como o relise é aproveitado pelos jornalistas nas redações e qual tipo de notícias ele é capaz de produzir na mídia, tendo como base este caso específico de divulgação. 


\begin{abstract}
The present study has as objective to describe and to characterize the release - textual product accomplished by the press consultantships for their customers' popularization in the media - as a new gender of the sphere of journalistic production. We opted for the focus discursive on the gender formulated by Bakhtin: the speeches are constituted social and historically and determined in agreement with their different production manners, such as the established relationships among the speakers.
\end{abstract}

To analyze this little known gender by the great public, it was necessary, in a first moment, to place the reader of this work in the universe of the press consultantships, describing a little of the history of its appearance and of the important paper of the release in the day by day of the communication offices.

Stepped on in the theories of the Bakhtin's trend about gender and their applications in the contemporary linguists' studies, it was possible to present a more detailed formulation on the discursive genders, as a support to the characterization of the release, evidencing the persuasive resources that permeate the texts produced by the press assistants.

The analysis of five relises produced by different press consultantships, approaching varied themes, revealed that, in spite of each one of them to focus in a specific public, their group presents aspects in common, configuring a gender with communicative function and own style.

We still offer, at the end of this work, on a sixth analyzed text, through articles published in the press, examples as the journalists take advantage of the release in their articles and the kind of news they are able to produce in the media, based on this specific case of publicizing. 


\section{Sumário}

Introdução

pg. 02

Capítulo 1

Assessoria de Imprensa

pg. 07

Capítulo 2

Os Gêneros Discursivos

pg. 13

O Relise como Gênero

pg. 19

Características Persuasivas do Relise

pg. 23

Capítulo 3

Análises do Corpus

pg. 31

3.1. O espetáculo das saladas no McDonald's

pg. 33

3.2. Uma cidade dentro da Febem

pg. 41

3.3. O jeans como imagem poética

pg. 49

3.4. Tecnologia no papel

pg. 56

3.5. Pioneirismo vindo de Portugal

pg. 62

Capítulo 4

Case GNT: Observação dos resultados na mídia

pg. 71

Considerações Finais

pg. 98

Anexos
Bibliografia 
INTRODUÇÃO 


\section{INTRODUÇÃO}

Algum tempo depois de terminar a faculdade de Jornalismo, deixei de lado a correria das redações de televisão para ingressar no crescente mercado de assessoria de imprensa. A intenção, na época, era conquistar uma estabilidade no horário de trabalho - praticamente impossível no ramo televisivo - para poder me dedicar também à carreira acadêmica.

Assim, nos últimos oito anos fui aprendendo e praticando um gênero discursivo específico desse segmento que, apesar de não ser tão novo, carece de atenção e estudo: o relise. Diariamente são redigidos e enviados à imprensa centenas de relises no Brasil todo, sobre os mais variados assuntos. A grande maioria segue um padrão pré-determinado por conveniência da profissão, outros poucos com base em manuais como o da FENAJ (Federação Nacional dos Jornalistas).

Pesquisando a fundo o tema, o que encontrei foi uma pequena bibliografia, muito mais voltada para as regras e normas que regem a profissão do assessor de imprensa do que para o produto linguístico que desenvolvem. A maior contribuição nessa área tem sido do jornalista Manuel Carlos Chaparro, docente da Escola de Comunicação e Arte da Universidade de São Paulo (ECA-USP).

Dentro desse panorama, decidi debruçar-me sobre o universo do relise, realizando o estudo de um corpus que possibilite configurar as características desse gênero, desde seu contexto de produção até as relações sócio-lingüisticas que nele se apresentam.

Marcuschi (2005), em um artigo sobre definição e funcionalidade dos gêneros textuais, vem de encontro a essa idéia: "Fruto do trabalho coletivo, os gêneros contribuem para ordenar e estabilizar as atividades comunicativas do dia-a-dia". Segundo ele, ainda: "surgem emparelhados a necessidades e atividades sócio-culturais, bem como na relação com inovações tecnológicas, o que é facilmente perceptível ao se considerar a quantidade de gêneros textuais hoje existentes em relação a sociedades anteriores à comunicação escrita". (p.19)

Faz-se necessário, então, retomar os conceitos dialógicos bakhtinianos: os discursos são constituídos sócio-historicamente e 
determinados de acordo com diferentes modos de produção e em função das relações estabelecidas entre os interlocutores.

Segundo Bakthin (2003), um texto reflete suas condições de produção e finalidades específicas utilizando três elementos lingüísticos - o conteúdo temático, o estilo e a construção composicional -, que "estão indissoluvelmente ligados no todo do enunciado e são igualmente determinados pela especificidade de um determinado campo de comunicação". O autor prossegue: "evidentemente, cada enunciado particular é individual, mas cada campo de utilização da língua elabora seus tipos relativamente estáveis de enunciados, os quais denominamos gêneros do discurso". (p. 262)

Aplicando essas noções ao produto lingüístico praticado pelas assessorias de imprensa, ou seja, aos relises, é possível observar que eles possuem parâmetros próprios, delimitados conforme necessidades definidas, que indicam se tratar de um gênero específico e diferenciado dentro da categoria jornalística.

Vale retomar aqui outra premissa bakhtiniana de que "a enunciação é produto da interação de dois indivíduos socialmente organizados e, mesmo que não haja um interlocutor real, este pode ser substituído pelo representante médio do grupo social ao qual pertence o locutor" (2002, p.112). Para ele, "essa orientação da palavra em função do interlocutor tem uma importância muito grande. Na realidade, toda palavra comporta duas faces. Ela é determinada tanto pelo fato de que procede de alguém, como pelo fato de que se dirige para alguém. Ela constitui justamente o produto da interação do locutor e do ouvinte" (p.113).

A questão levantada acima por Bakhtin vai se mostrar fundamental neste estudo, principalmente nas análises, uma vez que cada relise selecionado para o corpus é dirigido a um interlocutor diferente. Lembremos ainda que a premissa maior desse gênero é garantir uma eficácia comunicativa que gere resultados dentro da esfera de trabalho da assessoria de imprensa.

Para introduzir o leitor desta pesquisa no universo das Als, o primeiro capítulo oferece um pequeno resumo de como a profissão surgiu e proliferou 
no mundo todo, inclusive no que diz respeito à criação de seus regimentos internos e avanços tecnológicos ao longo do tempo.

No capítulo seguinte, propomos uma conceituação dos gêneros discursivos, a caracterização do relise e indicamos os recursos persuasivos que permeiam os textos produzidos pelos assessores de imprensa.

Depois, o trabalho traz a análise de seis relises, abordando diferentes temas: cidadania, moda, alimentação, varejo e telefonia. Complementando, transcrevemos um case do ramo do entretenimento, que, além da análise, trará alguns exemplos de notícias resultantes do relise, para observação do alcance do trabalho de divulgação do assessor de imprensa. 


\section{CAPÍTULO 1}


“Este não é um serviço de imprensa secreto. Todo nosso trabalho é feito às claras. Pretendemos fazer a divulgação das notícias. Isto não é agenciamento de anúncios. Se acharem que o nosso assunto ficaria melhor na seção comercial, não o usem.

Nosso assunto é exato. Maiores detalhes, sobre qualquer questão, serão dados prontamente. E qualquer diretor de jornal interessado será auxiliado, com o maior prazer, na verificação direta de qualquer declaração de fato.

Em resumo, nosso plano é divulgar, prontamente, para o bem das empresas e das instituições públicas, com absoluta franqueza, à imprensa e ao público dos Estados Unidos, informações relativas a assuntos de valor e de interesse para o público".

(CHAPPARO, Manuel Carlos [2003]. "Cem anos de assessoria de imprensa" in Assessoria de Imprensa e relacionamento com a mídia: teoria e técnica) 


\section{CAPÍTULO 1}

\section{ASSESSORIA DE IMPRENSA}

A epígrafe da página anterior transcreve a carta aos editores, datada de 1906, com a qual o jornalista norte-americano Ivy Lee marcou o surgimento da atividade hoje chamada de assessoria de imprensa. Há exatos 100 anos, Lee era o primeiro jornalista a abandonar a carreira nas redações para prestar serviços de relações públicas. E seu empregador era ninguém menos que John Rockfeller, o mais impopular homem de negócios dos Estados Unidos, naquela época, por conta da sangrenta greve da Colorado Full and Iron Company.

No documento, considerado histórico, Lee se colocava à disposição da imprensa para qualquer esclarecimento e se comprometia a fornecer, sempre, notícias verdadeiras e honestas aos jornalistas. De fato, ele cumpriu o prometido, mas para isso usou de táticas e técnicas capazes de influenciar a opinião da imprensa a favor de seu cliente. "Ivy Lee criou fatos noticiáveis, e com eles forneceu valores sobre os quais esculpiu, na opinião pública, a nova imagem de seu cliente" (DUARTE 2003, p.37).

E apesar de algumas práticas consideradas ilícitas - mas que continuam em voga atualmente, como os "agrados", presentes, favores, almoços e viagens -, com sua "carta de princípios" Ivy Lee estabeleceu, pela primeira vez, um conjunto de regras ético-morais que até hoje regem a profissão.

Pouco mais de duas décadas depois, com a queda da bolsa de 1929, a população americana assistia à profissionalização das assessorias de imprensa. Isso porque a nova categoria jornalística emergia como a única fonte capaz de suprir a necessidade de troca de informações entre as instituições, a imprensa e a população que se instaurou no país em meio a crise econômica.

Já bastante difundida nos Estados Unidos, a atividade cruza as fronteiras para o Canadá por volta de 1940, e, em menos de dez anos, já se espalha por toda a Europa, tendo como porta de entrada a França. Segundo Manuel Carlos Chaparro, as relações públicas prestadas pelos escritórios de 
assessoria de imprensa cresceram mais rápido nos países que copiaram o modelo norte-americano, entre eles o Brasil. "Depois da Segunda Guerra Mundial. E mais acentuadamente após a eleição de Juscelino Kubitschek, para aquí convergiram, com propriedade estratégica, os investimentos das grandes multinacionais - e com as fábricas vieram as relações públicas profissionalizadas e as práticas de assessoria de imprensa” (2003, p.41).

Data de 1961 o surgimento da assessoria de imprensa da Volkswagem, apontada por muitos como pioneira no mercado brasileiro. Conforme explica Jorge Duarte, "ela teria sido a primeira estrutura formada em uma organização privada para atuar com relacionamento planejado, sistematizado e permanente com a imprensa, numa perspectiva estratégica" (2003, p.85). Seus fundadores, os jonalistas Reginaldo Finotti e Alaor José Gomes, marcam história também uma década depois, com a criação da Unipress - primeiro escritório de imprensa reconhecido no Brasil - em 1971.

De lá para cá, o segmento de assessoria de imprensa é o que mais cresce no mercado jornalístico. Além disso, a atividade vem se profissionalizando cada vez mais e hoje conta não com uma simples "carta de princípios", mas com uma série de regras e rótulos reconhecidos pelos escritórios de $\mathrm{Al}$ e, principalmente, pelas redações.

De acordo com o Manual de Assessoria de Imprensa da FENAJ Federação Nacional dos Jornalistas -, o trabalho do assessor visa a contribuir para o aperfeiçoamento da comunicação entre as instituições (e não apenas empresas, mas também pessoas físicas e jurídicas) e a opinião pública. "Dentro de uma perspectiva social que privilegia essa última, a assessoria de imprensa agiliza e complementa o trabalho do repórter, subsidia-o e lhe oferece alternativas adequadas, garantindo o fluxo de informações para os veículos de comunicação e, conseqüentemente, para a sociedade com um todo".

Nas palavras de José Marques de Melo (1985, p. 13), "entre o repórter e a notícia antepõe-se uma verdadeira organização que, se não consegue eliminar a sua presença do universo do acontecimento, tenta estabalecer uma mediação". Segundo ele, as Als atuam como codificadoras de mensagens que traduzem em linguagem jornalística situações vividas fora do alcance do grande público. 
Mas, afinal, de que forma se caracteriza essa interface entre o assessor e o jornalista?

Seguindo os passo de Ivy Lee, toda a comunicação das Als com as redações se dá por intermédio de um texto escrito. Assim, para entender o papel de mediador que o assessor de imprensa exerce, entre as instituições e os órgãos da imprensa, é fundamental compreender as características únicas do press-release, a ferramenta lingüística empregada nessa mediação.

Conhecido também como release ou pela versão em português relise que inclusive será a utilizada neste estudo -, esse produto lingüístico típico das Als tem na explicação de Elisa Kopplin e Luiz Artur Ferraretto (2000) sua melhor definição:

"material de divulgação produzido pela assessoria, escrito de forma jornalística embora não tenha finalidade de ser utilizado como texto pronto pela imprensa. O objetivo do relise é sugerir o assunto, estimular a investigação. Não deve ser produzido indiscriminadamente ou banalmente em nenhuma situação. Para ser valorizado e, por conseqüência, aproveitado, deve conter uma notícia de real interesse. $O$ relise pode ou não ser utilizado por seus destinatários e o assessor não deve, em hipótese alguma, pressionar os jornalistas dos veículos para que divulguem as informações". (p. 146)

Por mais que o assessor de imprensa, assim como os demais jornalistas, almeje a imparcialidade no repasse das notícias, sabemos que a postura de neutralidade do enunciador é quase impossível. Isso porque, ao escrever, cada palavra, cada informação, cada orientação resultam de uma decisão e de uma escolha. Durante todo o tempo de sua atividade diária, o jornalista seleciona e opta. Ele vive enunciando, parabolizando, generalizando, definindo, montando tendências, compondo perspectivas, rejuntando elementos de seu repertório. $E$ tudo isso usando como instrumento a linguagem (DINES, 1986, p. 12), Sendo assim, é inevitável que tanto o recorte temático quanto a linguagem utilizada sejam cuidadosamente selecionados, a fim de se obter o resultado comunicacional desejado, permitindo-se, no caso do relise, vislumbrar as marcas enunciativas do texto empregadas pelo seu redator.

Partindo-se do pressuposto de Maingueneau (2001, p. 79) de que "como quem escreve não pode controlar a recepção de seu enunciado, é 
obrigado a estruturá-lo de maneira a torná-lo compreensível, ou seja, é obrigado a fazer de seu enunciado um texto, no sentido mais pleno do termo", o assessor de imprensa tem como prioridade redigir um relise que ofereça ao jornalista das redações uma notícia que desperte interesse, ao mesmo tempo que, implicitamente, apresente também todas as informações que deseja divulgar.

A título de curiosidade, vale destacar que a distribuição de relises pelas assessorias de imprensa evoluiu de acordo com a tecnologia. Se nos tempos de Lee o meio utilizado era o papel (carta), já fizeram parte da prática dos assessores o telex e o fax, sendo agora o e-mail a ferramenta mais freqüente. Este último, aliás, oferece aos escritórios de Als menor custo e maior instantaniedade na divulgação de seus relises. 


\section{CAPÍTULO 2}


"A riqueza e a diversidade dos gêneros do discurso são infinitas porque são inesgotáveis as possibilidades da multiforme atividade humana e porque em cada campo dessa atividade é integral o repertório de gêneros do discurso, que cresce e se diferencia à medida que se desenvolve e se complexifica um determinado campo."

(BAKHTIN, Mikhail [2003]. Estética da Criação Verbal, p.262) 


\section{CAPÍTULO 2}

\subsection{OS GÊNEROS DISCURSIVOS}

Falar em gêneros discursivos remete a diferentes correntes $\mathrm{e}$ categorizações. A noção de gênero vem desde a Antiguidade, quando Platão - cujo trabalho foi complementado pelo discípulo Aristóteles - fez a primeira distinção nas obras literárias, diferenciando os gêneros lírico, épico e dramático. A partir daí, muito se ampliou o estudo da questão do gênero, segundo diferentes modelos teóricos, tanto literários quanto lingüísticos. $O$ conceito sócio-interacionista de Bakhtin é o principal eixo que norteia nossa reflexão sobre o relise, ainda que outros autores também inspirem algumas de nossas colocações.

Vale recorrer a Anatol Rosenfeld em seus estudos sobre o teatro épico (1965, p.04): "A pureza em matéria de literatura não é necessariamente um valor positivo. Ademais, não existe pureza de gêneros em sentido absoluto". O teórico admite que a classificação das obras literárias por gênero torna-se indispensável dentro da necessidade de toda ciência de ordenar os fenômenos que podem ser observados nos textos, assim como seu modo de composição específico. Ele defende que a adoção de um sistema de gêneros pressupõe uma certa atitude extralingüística que se exprime na maneira de se comunicar.

Outros estudiosos da Lingüística e da teoria literária retomaram o tema, havendo, a respeito dos gêneros, diversas categorizações. Em função dos objetivos deste estudo, optamos, como já foi dito, pelo enfoque discursivo-interacionista de Bakhtin (2003):

"O emprego da língua efetua-se em forma de enunciados (orais ou escritos) concretos e únicos, proferidos pelos integrantes desse ou daquele campo da atividade humana. Esses enunciados refletem as condições especificas e as finalidades de cada referido campo não só por seu conteúdo (temático) e pelo estilo da linguagem, ou seja, pela seleção dos recursos lexicais, fraseológicos e gramaticais da língua, mas acima de tudo, por sua construção composicional." (p. 261)

$\mathrm{O}$ autor prossegue apontando como esses elementos se distinguem num enunciado: 
"Todos esse três elementos - o conteúdo temático, o estilo, a construção composicional - estão indissoluvelmente ligados no todo do enunciado e são igualmente determinados pela especificidade de um determinado campo da comunicação. Evidentemente, cada enunciado particular é individual, mas cada campo da utilização da língua elabora seus tipos relativamente estáveis de enunciados, os quais denominamos gêneros do discurso". (p.262)

Ainda com relação à teoria proposta por Bakhtin, que percebe o discurso como um produto social e, como tal, heterogêneo, variado e suscetível a mudanças, faz-se a divisão dos gêneros em dois tipos: primários (simples) e secundários (complexos).

Os chamados gêneros primários são aqueles que tem como origem as situações verbais espontâneas, não elaboradas. Por sua informalidade, costumam fazer uso imediato da linguagem oral e são freqüentes em enunciados da vida cotidiana. Já os gêneros secundários normalmente se estabelecem por meio da escrita, fazendo com que a relação do redator com a linguagem seja mais elaborada, construindo uma ação verbal muito mais complexa, evoluída e organizada. Podemos dizer que os gêneros secundários absorvem e modificam os primários, transformando-se dentro deles e adquirindo uma característica particular:

\footnotetext{
"No processo de sua formação eles [gêneros secundários] incorporam e reelaboram diversos gêneros primários (simples), que se formam nas condições da comunicação discursiva imediata. Esses gêneros primários, que integram os complexos, aí se transformam e adquirem um caráter especial: perdem o vínculo imediato com a realidade concreta e os enunciados reais alheios..." (p. 263)
}

Irene Machado (2005, p.152) retoma a proposta bakhtiniana sobre os gêneros, enfatizando a questão emergencial de a prosa reivindicar outros parâmetros de análise das formas interativas que se realizam pelo discurso: "Os estudos que Mikhail Bakhtin desenvolveu sobre os gêneros discursivos considerando não a classificação das espécies, mas o dialogismo do processo comunicativo, estão inseridos no campo dessa emergência".

Recorremos a Maingueneau (2001, p.59-61) para ampliar nossas considerações. Segundo ele, todo texto pertence a uma categoria de discurso, sendo que as categorias variam em função do uso que delas se faz. Para ele, os gêneros de discurso definem-se por "dispositivos de 
comunicação que só podem aparecer quando certas condições sóciohistóricas estão presentes". Aponta ainda para a distinção entre os gêneros e os tipos discursivos: os primeiros estão englobados nos segundos de acordo com os setores de atividade social dos quais fazem parte.

Ainda segundo Maingueneau, "os gêneros de discurso não podem ser considerados como formas que se encontram à disposição do locutor a fim de que este molde seu enunciado nessas formas. Trata-se, na realidade, de atividades sociais que, por isso mesmo, são submetidas a um critério de êxito" (p.65).

Dessa maneira, para que o texto possa efetivamente ser caracterizado como um gênero discursivo, ele deve englobar as "condições de êxito" propostas pelo lingüista:

- uma finalidade reconhecida: serve para garantir que o discurso esteja adequado ao público a que se destina.

- o estatuto de parceiros legítimos: o papel que devem assumir enunciador e co-enunciador no discurso.

- o lugar e o momento legítimos: são pontos constitutivos do discurso que muitas vezes parecem simplesmente intrínsecos, ou então são apresentados de forma totalmente adversa - desde que nesses casos o estranhamento causado tenha um sentido pré-determinado.

- um suporte material: refere-se à dimensão midiológica dos enunciados, que é capaz de modificar radicalmente um gênero discursivo de acordo com o suporte material utilizado.

- uma organização textual: diz respeito a dominar o gênero do discurso que se vai utilizar e ter consciência dos modos de encadeamento de seus constituintes nos mais diferentes níveis.

Helena Brandão (2000) remete a Filliolet (1987), que teria como pressuposto ideal um feixe de critérios lingüísticos que deveriam ser, ao mesmo tempo, bastante peculiares e bastante gerais. Bastante peculiares para que as realizações, sempre diferentes, sejam previsíveis em suas características pertinentes, desde que as condições de produção de um discurso dado sejam suficientemente reconhecidas. Bastante gerais, para fornecer uma lista das principais constantes de cada tipo isolado, cujas 
realizações em discurso não apresentem senão um caso particular de seleção.

Os gêneros discursivos seriam, por assim dizer, tipos relativamente estáveis de enunciados caracterizados por suas funções comunicativas, cognitivas e sóciodiscursivas:

\footnotetext{
"Uma abordagem que privilegie a interação não pode estudar o texto de forma diferenciada, em que, qualquer que seja o texto, vale o mesmo modo de aproximação. Uma abordagem que privilegie a interação deve conhecer os tipos diferentes de textos, com diferentes formas de textualização, visando a diferentes situações de interlocução" (BRANDÃO, 2000, p. 18)
}

Outra corrente importante no estudo dos gêneros é a Escola de Genebra, destacando-se o trabalho de J. Dolz e B. Schneuwly que retomam os conceitos-chave bakhtinianos. Para eles, "o gênero é um instrumento" (2004, p.23), o que faz de qualquer ato comunicacional uma atividade tripolar. Ou seja, a relação entre o sujeito e a situação, é "mediada por objetos específicos, socialmente elaborados, fruto das experiências das gerações precedentes, através dos quais se transmitem e se alargam as experiências possíveis" (2004, p.23). Esses instrumentos mediadores se organizam de acordo com elementos discursivos e marcas lingüísticas próprias, que distinguem e definem os diversos gêneros existentes.

No caso do relise, são os elementos discursivos - o que dizem? para quem? com qual finalidade? - que determinam as marcas lingüísticas. Por um lado, como se disse no início, existe o objetivo de manter a "neutralidade" do discurso. Por outro, o texto todo é permeado pela estratégia de persuadir o interlocutor. Se a empreitada for bem sucedida, será possível contar com ele para divulgar o produto a que o relise se refere.

Em função do público a que esse produto se destina, determinadas marcas lingüísticas são perceptíveis na superfície do texto. Por vezes, o registro de linguagem remete ao usuário do produto em questão. Em outros casos, recursos expressivos como metáforas, enumerações, figuras dão ao relise certo caráter poético que acentua seu aspecto persuasivo.

Com relação à diversidade dos gêneros, Dolz e Schneuwly propõem a divisão em cinco agrupamentos: narrar, relatar, argumentar, expor e 
descrever ações. A idéia é que cada um deles corresponda às principais finalidades sociais, sendo que os gêneros que fazem parte desses agrupamentos são relativamente homogêneos no que diz respeito às distinções tipológicas necessárias para se diferenciar internamente dos demais gêneros agrupados, ainda que apresentem marcas lingüísticas de sub-gêneros.

Os autores ainda advertem que "os agrupamentos assim definidos não são estanques com relação aos outros, não é possível classificar cada gênero de maneira absoluta em um dos agrupamentos propostos". No que se refere aos agrupamentos, pode haver uma confluência de categorias, sendo que a decisão do agrupamento em que se encaixa um gênero vai depender de sua característica mais predominante. 
"Os gêneros de discurso não podem ser considerados como formas que se encontram à disposição do locutor a fim de que este molde seu enunciado nessas formas. Trata-se, na realidade, de atividades sociais que, por isso mesmo, são submetidas a um critério de êxito."

(MAINGUENEAU, Dominique [2001]. Análise de textos de Comunicação, p.65) 


\subsection{O RELISE COMO GÊNERO}

Marcuschi (2005, p.21) diz que "os gêneros textuais surgem, situamse e integram-se funcionalmente nas culturas que se desenvolvem. Caracterizam-se muito mais por suas funções comunicativas, cognitivas e institucionais do que por suas peculiaridades lingüísticas e estruturais”. Essa é a realidade do gênero aquí estudado, hoje, no Brasil. Não existe uma fórmula precisa, um modelo único, uma "receita" exata de como se preparar um relise. A abrangência de temas e interlocutores é imensa, o que faz com que cada assessor busque uma abordagem diferenciada, em função dos jornalistas a quem se dirige. E o produto lingüístico (entenda-se relise) que irá realizar para cada um desses objetivos será específico.

$O$ relise pode receber diferentes roupagens, numa terminologia que se difunde, ainda sem nenhum critério, entre os assessores de imprensa. Um aviso de credenciamento, por exemplo, é um relise que se "tranveste" de convite para a imprensa comparecer - e confirmar presença, se credenciando com antecedência - para algum evento ou pronunciamento específico. Já numa nota social, o relise apresentado em um estilo textual que se assemelha ao utilizado pelos colunistas sociais. Isso porque, tão importante quanto ter em mãos um relise bem redigido, é ter a certeza de que o texto produzido tem o perfil idêntico ao do seu interlocutor.

Além disso, um único assunto pode gerar diferentes relises, um para cada interlocutor identificado. Pensemos hipoteticamente em uma agência de publicidade que, ao comemorar 10 anos de sucesso no mercado, decide mudar para uma sede própria maior que o atual escritório e fazer uma festa de inauguração do novo espaço. Temos nesse único evento um "gancho" para trabalhar diferentes segmento da imprensa. Os 10 anos de sucesso no mercado podem ser trabalhados, em números, junto aos jornalistas de economia e negócios. A mudança para uma sede própria - e maior demostra não só um crescimento da estrutura física, mas da empresa como um todo, que é uma pauta do interesse das publicações especializadas em propaganda e marketing. Já a festa em si abre mais um leque de opções de divulgação, de acordo com os atrativos: convite aos jornalistas para cobertura do evento, credenciamento de fotógrafos se forem comparecer 
celebridades, registro da festa nos sites de propaganda e marketing, notas sobre detalhes e curiosidades da comemoração para os colunistas sociais, etc.

Mas então, como tudo isso se enquadra num único gênero?

Vamos recorrer as "condições de êxito" propostas por Maingueneau e apresentadas anteriormente. $O$ relise tem:

- uma finalidade reconhecida, por ser um texto informativo que pretende despertar o interesse dos jornalistas capaz de suscitar matérias e reportagens sobre o assunto de que se trata;

- um estatuto de parceiros legítimos, uma vez que o assessor de imprensa se dirige, por intermédio dele, aos jornalistas das redações, numa relação de interação;

- o lugar e o momento legítimos, já que é elaborado tendo sempre em vista que deve ser de leitura fácil, rápida e atraente para que possa ser percebido na atribulada rotina das redações jornalísticas;

- um suporte material: o relise já é primordialmente um texto escrito impresso e sua execução em outra mídia o descaracterizaria automaticamente;

- uma organização textual, que mesmo não seguindo um modelo estático, traz em sua organização aspectos de textualidade (coesão e coerência) que dão sentido ao texto, além de uma carga persuasiva "disfarçada" de neutralidade; isto é, um conjunto de recursos de estilo que, apesar do tom aparentemente neutro, tem o efeito de persuadir o interlocutor.

Apesar de trazer uma organização e marcas lingüísticas próprias algumas delas se assemelham às de outros discursos jornalísticos - como o lead (abertura contendo o conjunto de informações mais relevantes do texto) e o freqüente emprego do tempo presente -, o ponto em que o relise se diferencia é seu papel de atividade sócio-discursiva. Para exercer com eficácia esse papel, o relise se reveste de outro aspecto estilístico importante. O emprego de recursos retóricos e poéticos que impressionem o interlocutor, de modo a persuadí-lo a divulgar o evento, idéia ou produto de que trata o relise. 
Em seus estudos sobre gêneros, Bakhtin sempre enfatizou o ângulo dialógico dos enunciados, como o princípio que rege a produção e a constituição dos sentidos de cada texto. No relise, a interação dialógica com os mais variados segmentos da imprensa está alicerçada no traço principal desse gênero, que é, através de sua realização lingüística, persuadir o jornalista das redações de que o que está sendo divulgado é uma notícia de interesse do grande público. Cabe salientar que, além de convencer o interlocutor, o relise também fornece a ele elementos para o seu texto de divulgação que, muitas vezes, transcreve trechos do próprio relise.

Marcuschi (2005) encerra para nós essa questão, ao afirmar que "quando dominamos um gênero textual, não dominamos uma forma lingüística e sim uma forma de realizar lingüisticamente objetivos e situações sociais particulares". Essa é a essência do gênero relise, usar da linguagem jornalística conhecida e praticada por seus interlocutores para criar um texto atraente - e supostamente imparcial - que seja realizado lingüisticamente de acordo com cada uma das relações discursivas sustentadas pelo assessor de imprensa. 
"Generalizando um pouco a questão, é possível afirmar que o elemento persuasivo está colado ao discurso como a pele ao corpo"

(CITELLI, Adilson [1991]. Linguagem e Persuasão, p. 6) 


\subsection{CARACTERÍSTICAS PERSUASIVAS DO RELISE}

O aspecto persuasivo do relise resulta do emprego de recursos expressivos, levando-o a aproximar-se, por vezes, do discurso poético ou literário, como será ilustrado, adiante, no capítulo de análises.

Para melhor compreender esse processo, vamos retomar as funções de linguagem propostas por Roman Jakobson (1977). Para ele, todo e qualquer ato de comunicação verbal está calcado em seis elementos fundamentais - remetente, destinatário, contexto, mensagem, contato e código - interligados entre si. O predomínio de um deles resulta numa função de linguagem específica, respectivamente - emotiva, conativa, referencial, poética, fática e metalingüística. Todas as funções definidas por Jakobson estão presentes nas situações de comunicação. Todavia, uma ou duas delas predominam sobre as outras. No caso específico do relise, a predominância mais acentuada é da função apelativa, seguida de perto pela função poética. Ao selecionar as palavras, o assessor também se preocupa em associá-las de modo a produzir expressividade no texto, recurso que, no caso do relise, funciona como elemento de persuasão.

Uma vez que o gênero relise visa a persuadir seu interlocutor, tornase pertinente recorrer, também, aos estudos sobre argumentação, começando por uma de suas principais bases teóricas: a proposta de Perelman (1970). O autor salienta a idéia de que a argumentação pode se apresentar como um ato de persuasão. Enquanto o ato de convencer é capaz de atingir um auditório universal por meio de um raciocínio lógico, o ato de persuadir se destina a um auditório particular, sem conduzir a certezas, mas levando a interferências que resultem na crença e aceitação por parte do interlocutor. Isso significa que, muito mais do que convencer que se situa no âmbito da razão -, o texto persuasivo visa a atingir o interlocutor por meio de argumentos plausíveis e verossímeis, com uma grande carga ideológica, apresentando razões capazes de despertar seus sentimentos e emoções, até chegar ao seu convencimento.

Ducrot (1978) ressalta, nesse sentido, uma estratificação do "dizer" (seja escrito ou falado), buscando delimitar os diferentes níveis de 
significação de um texto. São os conceitos de "posto, pressuposto, subentendido e implícito". Assim, tem-se que levar em conta que, inserido numa situação de comunicação, o texto está imbuído de intenções, que se realizam ou não, de acordo com a interpretação do interlocutor. O sentido, portanto, não se apresenta como algo já pré-existente à decodificação do texto, mas sobretudo como sendo constituído no momento da realização.

Entre os lingüistas contemporâneos brasileiros, quem traz uma contribuição importante para este trabalho é Adilson Citelli (1991). Retomando a tradição do discurso clássico, ele destaca a relação que Aristóteles fazia entre retórica e persuasão: "a retórica é a faculdade de ver teoricamente o que, em cada caso, pode ser capaz de gerar a persuasão" (p.10).

A Arte Retórica do filósofo grego sugere que todo texto tenha uma estrutura formada por um exórdio (introdução), narração (onde os fatos são arrolados), provas (elementos sustentáveis de argumentação) e perolação (conclusão). O relise costuma seguir essa proposta de Aristóteles, sendo focado principalmente no quesito provas, que é o ponto onde ganha força persuasiva para atingir seu objetivo. Além das provas - ou argumentos baseados em fatos - considerem-se, também, aqueles baseados em hipóteses, em conhecimento científico, etc.

Tanto se falou até agora sobre persuadir, mas qual seria sua melhor definição? Segundo Citelli, "persuadir, antes de mais nada, é sinônimo de submeter, daí sua vertente autoritária. Quem persuade leva o outro à aceitação de uma dada idéia. É aquele irônico conselho que está embutido na própria etimologia da palavra: per + suadere = aconselhar". E é exatamente esse tom que o assessor de imprensa busca no relise, aconselhar o jornalista sobre o que o produto (ou idéia) tem de diferencial que poderia servir como pauta para o seu veículo. Assim como existe o mito da neutralidade jornalística, o relise também tenta parecer imparcial e aparentar apenas servir de sugestão para o jornalista. Todavia, a grande carga persuasiva nele embutida sugere o contrário.

Chegamos aqui a uma outra questão fundamental: diferentemente dos jornalistas comuns, os assessores de imprensa apenas produzem textos positivos, destacando as qualidades e diferenciais de seus clientes. Isso 
significa que estão mentindo? $\mathrm{Na}$ verdade, poderíamos dizer que estão omitindo, ou, em outras palavras, apresentando dados parciais. É papel do assessor de imprensa filtrar as informações que possam repercutir de forma favorável para os seus clientes. Além disso, ele tem ainda a missão de transformar qualquer ponto negativo que possa vir à tona como algo positivo. Em ambos os casos, fará uso da persuasão para organizar seu discurso, de forma a construir um "efeito de verdade" no texto. Como explica Citelli, "é possível que o persuador não esteja trabalhando com uma verdade, mas tão somente com algo que se aproxime de uma certa verossimilhança ou simplesmente a esteja manuseando" (p.13).

Ele atenta ainda para o fato de que, "para se verificar a construção do discurso persuasivo, é necessário reconhecer a organização e a natureza dos signos lingüísticos. Afinal, é da inter-relação dos signos que se produz a frase, o período, o efeito" (p.23).

Falar em poesia num trabalho que se propõe a analisar textos jornalísticos pode causar, a primeira vista, certo estranhamento. $O$ contato com o gênero mostra, porém, que a aproximação é pertinente.

Retomemos aqui o conceito básico sobre funções da linguagem, proposto por Roman Jakobson: toda mensagem é organizada de acordo com a predominância de uma função dominante, partindo da premissa de que esse predomínio não exclui a presença das demais. Assim, além da função conativa - com apelo ao receptor da mensagem - e da função referencial - com a descrição do objeto da divulgação -, o discurso jornalístico de divulgação, pode, também, apresentar recursos poéticos. Neste caso, além do caráter estético, ele é empregado com finalidades específicas.

No caso do relise, que tem como principal objetivo persuadir o seu leitor, o emprego da poeticidade pode acontecer de diversas maneiras e em diferentes graus. Segundo Guaraciaba Micheletti, "o significado poético parece nascer de uma especialização da linguagem, já que a sua função básica, primeira, é a da comunicação" (1997, P.154)

Youri Tynianov também oferece sua contribuição com seus 'traços flutuantes'. Para ele, os traços criados pelo jogo de palavras que o compõe 
geram novos efeitos de sentido com uma finalidade própria: despertar o interesse do leitor para o seu produto.

Propomos uma ampliação da teoria apresentada por Tynianov, que, a nosso ver, não apenas permitiria identificar um "semantismo aparente" nas palavras empregadas nos poemas, mas também em trechos em prosa. Ele retoma a tese fundamental de Alfred Rosenstein, um dos primeiros especialistas da semântica: "a significação da palavra é determinada pelo conjunto (Gesamtheith) das relações não só das noções, mas também das emoções" (Tynianov, 1982, p.17). Essas relações certamente serão percebidas com mais facilidade num poema, contudo isso não impede que apareçam num texto em prosa e - porque não? - num relise.

Segundo Jean Cohen, "a diferença poesia/não poesia é procurada num dualismo semântico que opõe dois tipos de sentido, 'noético (ou conceptual) e 'patético' (ou afectivo), aos quais estão ligadas respectivamente as dimensões fenomenológicas clareza/obscuridade e intensidade/neutralidade" (1982, p.53). Essa definição complementa nossa proposta a respeito do relise.

Apesar de inserido no contexto da divulgação jornalística - que supõe "clareza" e "neutralidade" -, não fica necessariamente proibida a presença do poético. Uma vez que se propõe a ser um discurso informativoargumentativo, visando à persuasão do leitor ao qual se destina, a suposta "neutralidade" dá margem a uma escolha semântica que pode também se apoiar na combinação de vocábulos, em função de "parentescos" sonoros conforme a conceituação de função poética proposta por Jakobson (1977). Embora aparente imparcialidade, na verdade, o relise pretende "vender" um valor, um produto, uma idéia, um conceito.

Voltemos ainda ao nosso ponto de partida - as funções da linguagem de Jakobson. Josette Jolibert afirma que "a função poética está centrada na própria mensagem (no sentido lingüístico da palavra, onde o emissor envia uma mensagem para o destinatário)" (1994, p.203). Em outras palavras, o caráter poético de um texto leva o leitor a prestar atenção no próprio texto além de perceber, também, os demais aspectos dele. Mesmo não sendo a função predominante num texto de assessoria de imprensa, ela se faz presente no relise e é um dos motivadores do poder persuasivo do texto. 
Como o próprio Jakobson define, em grifo da autora: a poética "é a finalidade da mensagem como tal, o acento colocado na mensagem por sua conta própria". Assim, levar a poeticidade em consideração na análise do corpus deste trabalho, oferece mais uma vertente para buscar e delinear as características próprias do gênero relise e sua eficácia junto ao público-alvo.

Ao abordar o relise, não podemos nos esquecer ainda da competência textual do assessor de imprensa, principalmente no que diz respeito à coesão e à coerência que irá empregar em seu texto. Todavia, não vamos aqui nos estender muito na conceituação desses dois recursos textuais, pois, apesar de fundamentais, ambos são facilmente percebidos nos textos analisados.

Em poucas palavras, podemos conceituar a coesão textual como as relações de sentido existentes no interior de um texto e que o definem como tal. Para isso, destacam-se cinco mecanismos de coesão: por referência, substituição, elipse, conjunção e léxico. Já a coerência está ligada não somente à uma continuidade semântica do texto, mas a sua organização subjacente, possibilitando a atribuição de um sentido unitário ao texto, decorrente da progressão temática.

Coesão e coerência se relacionam entre si, como explicam Koch \& Travaglia (2002, p.52):

“(...) a separação da coesão e da coerência não é tão nítida quanto às vezes se pensa e sugere. Na verdade, a coesão tem relação com a coerência na medida em que é um dos fatores que permite calculá-la e, embora do ponto de vista analítico seja interessante separá-las, distinguí-las, cumpre não esquecer que são duas faces do mesmo fenômeno".

Entre as principais obras sobre o assunto destacam-se Halliday \& Hasan (Cohesion in English, 1976) e Beugrand \& Dressler (Introduction to Text Linguistics, 1981). A gramática de Mira Mateus (1983) também é uma fonte importante para essas questões gramaticais em língua portuguesa. Já no Brasil, as duas autoras que serviram de base para este trabalho foram Ingedore Villaça Koch e Leonor Lopes Fávero. 
Retomando o que foi dito até aqui, acreditamos ser possível considerar o relise como um novo gênero, de caráter eminentemente persuasivo, com algumas marcas lingüísticas presentes em diferentes textos jornalísticos - dado o seu caráter informativo - além de outras que the são próprias e que têm o papel de acentuar o aspecto persuasivo. Podemos dizer, ainda, que o relise remete a um gênero híbrido: informativo, ao apresentar o produto; argumentativo, ao buscar persuadir o interlocutor; poético, ao envolver a atenção dele, graças ao emprego de recursos expressivos.

Passemos às análises, que deverão ilustrar todas essas características. 
CAPÍTULO 3 
"Fruto do trabalho coletivo, os gêneros contribuem para ordenar e estabilizar as atividades comunicativas do dia-adia. São entidades sócio-discursivas e formas de ação social incontornáveis em qualquer situação comunicativa. No entanto, mesmo apresentando alto poder preditivo e interpretativo das ações humanas em qualquer contexto discursivo, os gêneros não são instrumentos estanques e enrijecedores da ação criativa".

(MARCUSCHI, Luiz Antônio [2005]. "Gêneros textuais: definição e funcionalidade" in Gêneros Textuais \& Ensino, p.19) 


\section{CAPÍTULO 3}

\section{ANÁLISES DO CORPUS}

Hoje, o universo do relise é abrangente e sua produção extensa. Por esse motivo, utilizamos dois critérios para restringir nossa seleção. Primeiro, optamos por textos bem redigidos, que pudessem ilustrar as hipóteses propostas servindo como "modelos" desse gênero. Segundo, buscamos diversificar, isto é, mesclar textos sobre diferentes assuntos - cidadania, moda, alimentação, entretenimento, varejo e telefonia - para que fosse possível ilustrar que, independente do conteúdo temático, a organização textual segue normas e padrões que permitem caracterizar o relise como um gênero específico.

As análises seguem etapas, de acordo com as características de cada texto. A cada fragmento, serão analisadas as marcas formais e estilísticas, os elementos de coerência e coesão e os recursos persuasivos, tendo sempre em vista a premissa de que o relise é elaborado com a finalidade de despertar o interesse do seu público-alvo, o jornalista das redações. 
"A gente não quer só comida a gente quer comida, diversão e arte.

a gente não quer só comida,

a gente quer saída para qualquer parte.

a gente não quer só comida,

a gente quer bebida, diversão, balé.

a gente não quer só comida,

a gente quer a vida como a vida quer."

(Comida, Titãs, 1987) 


\title{
3.1. O ESPETÁCULO DAS SALADAS NO MAC DONALD'S
}

\author{
O relise abaixo busca construir em suas linhas - e entrelinhas - uma \\ imagem sólida e positiva da rede internacional de "fast-foods" McDonald's, \\ no lançamento de seus produtos especiais de verão, em 2004:
}

\section{Saladas do McDonald's chegam ao prato em porções mais generosas}

Com embalagem inédita, as novas versões da Salad Green e da Salad Green Chicken são as maiores novidades da campanha de verão da rede, que traz mais quatro lançamentos

As saladas do McDonald's são o prato do dia, ou melhor, da temporada. A rede de restaurantes tornou ainda mais generosas as porções da Salad Green e da Salad Green Chicken - que passaram de 117g para $142 \mathrm{~g}$, e de $147 \mathrm{~g}$ para cerca de $215 \mathrm{~g}$, respectivamente - e começa agora a servi-las em pratos. As novas versões dos produtos e sua embalagem - nunca antes utilizada pela empresa no Brasil - são os principais destaques do Verão McDonald's 2004. A campanha, que começou em 27 de dezembro e se estenderá até 29 de fevereiro, apresenta outros quatro saborosos lançamentos: um sanduíche, duas sobremesas e um suco.

A estréia das saladas no cardápio da rede ocorreu há três anos, durante o Verão McDonald's 2001. O sucesso foi tão grande que a rede sempre empenhada em oferecer qualidade e variedade a seus clientes incorporou os produtos definitivamente ao cardápio no final daquele ano. Antes servidas em copos plásticos de $500 \mathrm{ml}$, as saladas conquistaram, em particular, o paladar feminino, que tem predileção por refeições mais leves e, também, à base de frango.

As novas versões das Salad Green e da Salad Green Chicken, que podem ser saboreadas com os molhos Caesar e Vinagrete, vieram para ficar. Já os demais lançamentos do Verão McDonald's 2004 permanecerão em cartaz durante a campanha. É o caso do sanduíche McXSalada Bacon, produto sazonal que volta regularmente ao cardápio, sempre com grande aceitação. A mesma regra vale para as duas sobremesas da temporada - 0 Novo Muito Tudo e o Novo Sundae de Framboesa, ambos à base de sorvete de baunilha - e o McFruit Limão, a quarta opção de sabor da nova linha de sucos do McDonald's Brasil, desenvolvida sob medida pela Minute Maid, empresa do Grupo Coca-Cola.

O Verão McDonald's 2004 será divulgado em campanha publicitária assinada pela Taterka Comunicações. O slogan "amo muito meu verão" terá presença de destaque em dois filmes de 45 segundos, spots de rádio, outdoors, banners na Internet e peças de mobiliário urbano. No interior dos restaurantes, displays, móbiles, faixas e embalagens coloridas darão o tom da nova estação.

\section{VERÃO McDONALD'S 2004 - LANÇAMENTOS}

Green Salad: alface americana, alface romana, alface lisa, cenoura, repolho roxo, lascas de queijo parmesão e tomate;

Green Salad Chicken: alface americana, alface romana, alface lisa, cenoura, repolho roxo, lascas de queijo parmesão e tiras de filé de frango empanado crocante; 
McXSalada Bacon: hambúrguer de carne bovina, molho tipo maionese, tomate, alface, queijo e duas fatias de bacon;

Novo Muito Tudo: sorvete de baunilha, com cobertura de morango e chocolate, farofa de cereal tostado e dois bijus;

Novo Sundae de Framboesa: sorvete de baunilha, com calda de framboesa;

McFruit Limão

Em linhas gerais, o texto remete o interlocutor a dois temas centrais que perpassam todo o conjunto: a excelência da empresa e o "espetáculo" dos produtos que oferece. Enquanto as novidades do cardápio de verão são apresentadas ao longo do texto, as informações institucionais são reforçadas por meio de recursos diversos.

Logo no primeiro parágrafo, são trazidos dois dados relativos aos novos alimentos entre travessões: "que passaram [as saladas Salad Green e Salad Green Chicken] de $117 \mathrm{~g}$ para 142g, e de $147 \mathrm{~g}$ para cerca de $215 \mathrm{~g}$, respectivamente" e "nunca antes utilizada [nova embalagem em pratos] pela empresa no Brasil". Ao fazer uso de medidas exatas o anunciante revela a intenção de evidenciar a precisão com que são elaborados os produtos da marca. É como se as saladas fossem realmente pesadas uma a uma, agora que são servidas no prato e não mais num copo de $500 \mathrm{ml}$.

As saladas do McDonald's são o prato do dia, ou melhor, da temporada. A rede de restaurantes tornou ainda mais generosas as porções da Salad Green e da Salad Green Chicken - que passaram de 117g para $142 \mathrm{~g}$, e de $147 \mathrm{~g}$ para cerca de $215 \mathrm{~g}$, respectivamente - e começa agora a servi-las em pratos. As novas versões dos produtos e sua embalagem nunca antes utilizada pela empresa no Brasil - são os principais destaques do Verão McDonald's 2004. A campanha, que começou em 27 de dezembro e se estenderá até 29 de fevereiro, apresenta outros quatro saborosos lançamentos: um sanduíche, duas sobremesas e um suco.

Ainda no trecho inicial, destaca-se um jogo sintático paralelístico entre substantivos e adjetivos em duas expressões: "generosas porções" e "saborosos lançamentos". "Generoso", adjetivo, remete ao campo das atitudes; seu emprego junto ao substantivo "porções" associa ao índice quantitativo [grandes] um valor ético que traz implícitas as intenções do anunciante. Inversamente, o adjetivo "saborosos" - do campo semântico da "alimentação"- aparece, aqui, combinado ao substantivo "lançamentos", hiperônimo para qualquer produto - alimentício ou não. Assim, ao dinamismo 
da empresa que sempre lança coisas novas, superpõe-se a sugestão gustativa permanentemente associada a sua linha de criações.

Esses dois jogos sintáticos-semânticos, inclusive, surgem como inferências no texto - uma pressuposta e outra subentendida -, que reforçam a idéia da aceitação e sucesso de seus produtos no mercado. Em “ainda mais generosas" temos o pressuposto de que as porções de salada que faziam parte do cardápio já eram generosas, enquanto em "outros quatro saborosos lançamentos" subentende-se que, assim como as saladas, os demais lançamentos também são saborosos. Em nenhum dos casos acima temos a comprovação do que é dito (que, efetivamente, as porções são generosas e os lançamentos saborosos), mas a forma como essas informações vêm embutidas no discurso muitas vezes passa despercebida, devido ao seu efeito argumentativo habilidoso e sutil que, muitas vezes, nem é questionado pelo receptor da mensagem, no ato da leitura.

Passando agora para alguns recursos coesivos utilizados no texto, temos no trecho em questão duas elipses: "as saladas do McDonald's são o prato do dia, ou melhor,(...) da temporada" e "A campanha que começou em 27 de dezembro e(...) se estenderá até 29 de fevereiro". Esse recurso estende o ritmo da frase e, indiretamente, intensifica o valor das novidades de verão apresentadas. Há inúmeros elementos de referências às saladas ("servi-las em pratos/ "sua embalagem"/“que passaram”), com o efeito de manter a progressão temática cujo eixo são as estrelas do cardápio de verão.

No parágrafo seguinte, aparece a primeira indicação da temática "espetáculo" - que será intensificada à medida que o texto for progredindo -, com a utilização de termo do campo semântico do espetáculo: "estréia". Assim, por extensão, sugere-se a "salada" como "artista" e, conseqüentemente, o "cardápio" como "palco". Observem-se os grifos:

A estréia das saladas no cardápio da rede ocorreu há três anos, durante o Verão McDonald's 2001. O sucesso foi tão grande que a rede sempre empenhada em oferecer qualidade e variedade a seus clientes incorporou os produtos definitivamente ao cardápio no final daquele ano. Antes servidas em copos plásticos de $500 \mathrm{ml}$, as saladas conquistaram, em particular, 
o paladar feminino, que tem predileção por refeições mais leves e, também, à base de frango. (grifos nossos)

Além disso, a rede se apropria de uma estação do ano para recriar um momento só seu, como se fosse exclusivo, ao dizer que a estréia das saladas ocorreu "durante o Verão McDonald's 2001". Novamente a idéia de que no McDonald's tudo é um grande espetáculo, até mesmo a chegada do verão, que ganha nome e cardápio próprios.

No fragmento, novamente os travessões destacam uma assertiva modalizadora sobre a filosofia da empresa, "sempre empenhada em oferecer qualidade e variedade aos seus clientes". Numa aparente neutralidade, o sujeito discursivo busca dar uma "voz de autoridade" ao que é expresso no texto, já que na verdade a rede McDonald's não prima por qualidade e variedade, mas, ao contrário, por encabeçar a massificação típica das redes de fast-food.

Outro exemplo da tentativa de cativar o jornalista, está na última frase do fragmento: "as saladas conquistaram, em particular, o paladar feminino", alegando que as mulheres "tem predileção por refeições mais leves e, também, à base de frango", e sugerindo assim um diferente viés para a publicação da notícia.

Nos dois últimos parágrafos, o foco passa das saladas para os demais produtos especiais que serão comercializados durante o verão, sem fugir à temática do texto. O tópico "espetáculo" segue se ampliando, ao apresentar os demais lançamentos, entre eles as "sobremesas da temporada" que "permanecerão em cartaz" durante toda a campanha e terão "presença de destaque" em diversas peças publicitárias, além de variados mobiliários urbanos que "darão o tom" da nova estação no interior das lanchonetes da rede que funcionarão como palco para todo esse sucesso.

Apoiando a construção de unidades verbais significativas, são utilizados diversos mecanismos de coesão seqüencial ao longo do relise, com o intuito de melhorar a expressividade do enunciado. Esses operadores argumentativos permeiam o texto de diversas formas, como é o caso do parágrafo em questão, no qual cada produto recebe uma denominação que 
o complementa: as novas versões da Salad Green e da Salad Green Chicken, "que podem ser saboreadas com os molhos"; o McXSalad Bacon, "produto sazonal que volta regularmente ao cardápio" - e mais: "sempre com grande aceitação" -; as novas sobremesas Novo Muito Tudo e Sundae de Framboesa, "ambas à base de sorvete de baunilha"; e o McFruit Limão, "desenvolvido sob medida".

\footnotetext{
"As novas versões das Salad Green e da Salad Green Chicken, que podem ser saboreadas com os molhos Ceasar e Vinagrete, vieram para ficar. Já os demais lançamentos do Verão McDonald's 2004 permanecerão em cartaz durante a campanha. É o caso do sanduíche McXSalada Bacon, produto sazonal que volta regularmente ao cardápio, sempre com grande aceitação. A mesma regra vale para as duas sobremesas da temporada - o Novo Muito Tudo e o Novo Sundae de Framboesa, ambos à base de sorvete de baunilha e o McFruit Limão, a quarta opção de sabor da nova linha de sucos do McDonald's Brasil, desenvolvida sob medida pela Minute Maid, empresa do Grupo Coca-Cola. (grifos nossos)
}

Vale destacar ainda que é só nesse trecho do texto que os lançamentos, descritos no primeiro parágrafo como "um sanduíche, duas sobremesas e um suco", recebem efetivamente sua denominação: "McXSalad Bacon, Novo Muito Tudo, Sundae de Framboesa e McFruit Limão"; como se, até então, fossem coadjuvantes das saladas e só a partir deste momento entrassem realmente "em cena". Neste último, inclusive, a citação do fabricante, a "Minute Maid, empresa do Grupo Coca-Cola", é introduzida para dar mais credibilidade à nova bebida, por meio da referência a um nome de sucesso no mercado nacional e internacional.

O fragmento seguinte dá destaque para a campanha publicitária, que segue a linha temática do Verão McDonald's com o slogan original ("amo muito tudo isso"), adaptado para a estação, "amo muito meu verão". Aqui ainda o texto sugere que o verão do McDonald's é o mesmo que o do leitor, buscando gerar o maior grau de envolvimento e identidade entre a rede de fast-food e o seu consumidor em potencial.

Com relação ao plano de mídia previsto para a campanha, temos uma enumeração cumulativa - filmes, spots, outdoors, banners e mobiliário urbano - que pretende mostrar o grande investimento realizado em marketing. $\mathrm{E}$, para que esses detalhes não se percam em meio ao discurso, 
o redator remete novamente a termos que retomam a temática do "espetáculo":

O Verão McDonald's 2004 será divulgado em campanha publicitária assinada pela Taterka Comunicações. O slogan "amo muito meu verão" terá presença de destaque em dois filmes de 45 segundos, spots de rádio, outdoors, banners na Internet e peças de mobiliário urbano. No interior dos restaurantes, displays, móbiles, faixas e embalagens coloridas darão o tom da nova estação. (grifos nossos)

Quanto ao trecho final do relise, trata-se de descrição, marcada, em todo o conjunto, por enumerações e efeitos sonoros; e, no início, por repetições, indicados por sublinhados e grifos nossos:

\footnotetext{
VERÃO McDONALD'S 2004 - LANÇAMENTOS

Green Salad: alface americana, alface romana, alface lisa, cenoura, repolho roxo, lascas de queijo parmesão e tomate;

Green Salad Chicken: alface americana, alface romana, alface lisa, cenoura, repolho roxo, lascas de queijo parmesão e tiras de filé de frango empanado crocante;

McXSalada Bacon: hambúrguer de carne bovina, molho tipo maionese, tomate, alface queijo e duas fatias de bacon;

Novo Muito Tudo: sorvete de baunilha com cobertura de morango e chocolate, farofa de cereal tostado e dois bijus;

Novo Sundae de Framboesa: sorvete de baunilha, com calda de framboesa;

McFruit Limão
}

Cabe destacar que a definição do parágrafo acima como descritivo está baseada na teoria dos modos de organização do discurso proposta por José Luiz Fiorin (1994). Para ele, duas premissas caracterizam o modo de organização descritiva: ser um texto figurativo - nomeia, localiza e atribui qualidades usando termos concretos - e não explicitar nenhum tipo de transformação. Temos claramente essas duas características pressupostas na descrição. A primeira, ao trazer nominalmente a lista de ingredientes que fazem parte de cada produto; e a segunda, ao presumir que estes sejam montados na cozinha da lanchonete, mas deixando essa transformação apenas implícita no texto. Na realidade, esse trecho obedece às exigências da legislação brasileira a respeito do consumo de produtos alimentícios, sendo, portanto, uma das características do relise. 
Como se viu, a primeira análise mostrou de que forma um relise sobre produtos alimentícios utiliza recursos diversos para criar um efeito persuasivo, tendo como eixo principal alusões metafóricas ao campo do espetáculo. 
"A criança terá direito a receber educação, que será gratuita e compulsória pelo menos no grau primário. Ser-lhe-á propiciada uma educação capaz de promover a sua cultura geral e capacitá-la a, em condições de iguais oportunidades, desenvolver as suas aptidões, sua capacidade de emitir juízo e seu senso de responsabilidade moral e social, e a tornar-se um membro útil da sociedade."

(Estatuto da Criança e do Adolescente/Unicef Brasil) 


\subsection{UMA CIDADE DENTRO DA FEBEM}

O relise que se segue foi divulgado pela assessoria de imprensa da Febem (Fundação Estadual do Bem-Estar do Menor) de São Paulo com o intuito de apresentar à mídia o maior complexo da Instituição, no bairro do Tatuapé.

Já no título é possível perceber a grandiosidade que permeia todo o texto, reforçado pelas enumerações e citações quantitativas. Numa primeira leitura, identifica-se, no parágrafo inicial, um grande número de substantivos, acompanhados de informações numéricas, precedendo um período com duas orações que apresenta a instituição.

O que se constrói no texto é uma peça em que predomina o ponto de vista estatístico, baseado em fatos quantitativos. A coesão e a coerência apóiam-se numa série de elementos de caráter mensurável; enumeração cumulativa de todas as vantagens que a unidade da Febem no Tatuapé oferece aos seus internos:

\section{Uma Cidade dentro da Febem}

Alamedas arborizadas, escola para 500 adolescentes, posto médico, teatro com 400 lugares, biblioteca com 2.000 livros, padaria, loja, piscina, quadras, campo de futebol, academia, estúdio fotográfico, emissora de rádio. Essa poderia ser a descrição de uma cidade qualquer do interior paulista, mas se trata do maior complexo da Febem, no bairro do Tatuapé.

Com mais "habitantes" que municípios como Alvilândia, Borá, Dolcinópolis, Flora Rica, São João de Iracema ou Santa Salete, o Complexo deixa evidente a sua grandiosidade nos números: 230 mil $\mathrm{m}^{2}$ abrigam 17 unidades de internação, com 1.560 adolescentes e 1.300 funcionários. Por dia são servidas 9.000 refeições e circulam semanalmente por suas ruas uma média de 400 veículos. Nos finais de semana, quando acontecem as visitas, o Tatuapé aumenta o número da população: são cerca de 1.500 visitantes. Só em 2003, deram entrada no Complexo 2.800 jovens e outros 1.600 foram desinternados.

Todas as unidades do complexo oferecem ensino fundamental e médio, em salas de aula, além de atividades profissionalizantes, culturais e esportivas. Os jovens podem escolher entre atividades como artes plásticas, biscuit, digitação, educação ambiental, elétrica residencial, fotografia, informática, mecânica, pintura automotiva, manutenção de microcomputador, panificação, confeitaria, serigrafia, arraiolo, artesanato, tapeçaria, acabamento em móveis, pirogravura, cartonagem, encadernação, fábrica de bolas, pintura em vidro, capoeira, oficina de percussão, cavaco, teclado, violão, arte circense, canto coral, dança de rua, teatro, orquestra, produção de vídeo, confeç̧ão de berimbau, atletismo, basquete, boxe, cama elástica, ciclismo, futebol de campo, futebol de salão, futebol society, ginástica, ginástica 
acrobática, handebol, musculação, pebolim, skate, tênis de mesa, tênis de quadra, voleibol e xadrez.

O Complexo também tem uma escola profissionalizante e uma escola de ensino formal. A Escola Profissionalizante Marina Vieira de Carvalho Mesquita oferece em suas dependências 31 oficinas, além de coordenar as atividades profissionalizantes realizadas dentro de cada unidade. Já a Escola Oficina Rosmay Kara José é a responsável pelo ensino fundamental e médio. Recebe em suas dependências, os jovens das unidades que não têm salas de aula. Dentro do Complexo também funcionam a Divisão de Saúde, Divisão de Segurança, manutenção, lavanderia e cozinha industrial que atendem grande parte das unidades do Estado.

O PREFEITO - No comando desta super-estrutura desde abril de 2003, está o diretor de divisão, Celso Vieira. Formado em administração de empresas, com especialização em recursos humanos, o "prefeito" do Tatuapé, como é carinhosamente chamado, implantou um estilo diferente de gerenciamento, valorizando a formação de equipes e treinamento dos funcionários. "Respeitando as características de cada unidade e seguindo um padrão, dei autonomia para que os diretores pudessem trabalhar de acordo com as suas necessidades. Esse foi um dos pontos principais para que as unidades funcionassem de maneira tranqüila durante o ano", explica. Outro fator importante é que o diretor do Complexo começou, há quinze anos, como funcionário de pátio. "Essa experiência do monitor que virou diretor de divisão faz com que os funcionários se sintam mais próximos e o entrosamento com a área técnica é muito maior", conclui Vieira

HISTÓRIA - Em 1902, com o projeto de criação de um instituto disciplinar para jovens infratores, do chefe de polícia de São Paulo, Cardoso de Almeida, o governo do Estado desapropriou a Chácara do Belém e inaugurou a Escola Correcional. A idéia era que lá fossem recolhidos jovens abandonados e pequenos criminosos, que até então ficavam em cadeias com adultos. O primeiro interno chegou à escola em 23 de fevereiro de 1902.

SP 450 ANOS - A "cidade" da Febem também irá comemorar os 450 anos da capital paulista, com o $5^{\circ}$ Encontro de Dança de Rua, no dia 25 de janeiro, às 11 horas. São cerca de 300 adolescentes que participam da oficina de Dança de Rua, promovida em várias unidades do Estado pelo Ballet Stagium. Ao final do evento, os participantes cantam parabéns para a cidade com um bolo feito pelos próprios adolescentes do Tatuapé.

O parágrafo inicial evidencia a expressividade das vogais com a assonância do fonema /a/, o mais oral e sonoro do nosso sistema fonológico, logo nas primeiras duas palavras. "Alämedâs arborizadalas" fazem um dueto forte e nítido, que reforça ainda a impressão auditiva das consoantes sonoras que acompanham - ///, /m/, /d/, /b/, /r/, /z/, /d/. Com relação ao conteúdo, a nominalização e a enumeração cumulativa conferem a um trecho do texto um caráter estático. Nos elementos apresentados, o maior espaço é concedido ao cenário: 
Alamedas arborizadas, escola para 500 adolescentes, posto médico, teatro com 400 lugares, biblioteca com 2.000 livros, padaria, loja, piscina, quadras, campo de futebol, academia, estúdio fotográfico, emissora de rádio. Essa poderia ser a descrição de uma cidade qualquer do interior paulista, mas se trata do maior complexo da Febem, no bairro do Tatuapé

Aparecem dois únicos verbos. Um deles está no futuro do pretérito do modo indicativo, ("poderia"), remetendo a enunciação ao campo da possibilidade ou hipótese. Ainda sobre esse fragmento, seria importante ressaltar, no que diz respeito ao conteúdo, a comparação entre a Febem e uma cidade do interior, idéia que se anuncia já no título.

No parágrafo seguinte, uma série de números sobre o Complexo da Febem no Tatuapé salta aos olhos, no intuito de, como o próprio texto sugere, deixar "evidente a sua grandiosidade". Aqui, aparecem mais dois indícios aproximativos entre a Instituição e a Cidade: uma explícita, quando comparada a outros municípios paulistas, e outra metafórica - porém demarcada - ao nomear os internos como "habitantes".

Com mais "habitantes" que municípios como Alvilândia, Borá, Dolcinópolis, Flora Rica, São João de Iracema ou Santa Salete, o Complexo deixa evidente a sua grandiosidade nos números: 230 mil $^{2}$ abrigam 17 unidades de internação, com 1.560 adolescentes e 1.300 funcionários. Por dia são servidas 9.000 refeições e circulam semanalmente por suas ruas uma média de 400 veículos. Nos finais de semana, quando acontecem as visitas, o Tatuapé aumenta o número da população: são cerca de 1.500 visitantes. Só em 2003, deram entrada no Complexo 2.800 jovens e outros 1.600 foram desinternados.

Nesse trecho mais uma vez os verbos geram um efeito de sentido decorrente do emprego de formas no presente, marcando ações permanentes: "Por dia são servidas 9.000 refeições e circulam semanalmente por suas ruas uma média de 400 veículos. Nos finais de semana, quando acontecem as visitas, o Tatuapé aumenta o número da população: são cerca de 1.500 visitantes".

O terceiro parágrafo é marcado por mais uma enumeração cumulativa, acrescida de novos dados quantitativos que parecem indicar argumento de autoridade. Aparece, inicialmente, uma grande diversidade de atividades profissionalizantes oferecidas aos jovens, desde o tradicional 
ensino fundamental e médio até opções culturais e esportivas. No segundo período, o processo de nominalização é quase excessivo, beirando a saturação. A ausência de artigo acaba amplificando ainda mais essa enumeração, chegando a "tirar o fôlego" do leitor com uma lista enorme da variedade de atividades oferecida pela Instituição.

Todas as unidades do complexo oferecem ensino fundamental $e$ médio, em salas de aula, além de atividades profissionalizantes, culturais e esportivas. Os jovens podem escolher entre atividades como artes plásticas, biscuit, digitação, educação ambiental, elétrica residencial, fotografia, informática, mecânica, pintura automotiva, manutenção de microcomputador, panificação, confeitaria, serigrafia, arraiolo, artesanato, tapeçaria, acabamento em móveis, pirogravura, cartonagem, encadernação, fábrica de bolas, pintura em vidro, capoeira, oficina de percussão, cavaco, teclado, violão, arte circense, canto coral, dança de rua, teatro, orquestra, produção de vídeo, confecção de berimbau, atletismo, basquete, boxe, cama elástica, ciclismo, futebol de campo, futebol de salão, futebol society, ginástica, ginástica acrobática, handebol, musculação, pebolim, skate, tênis de mesa, tênis de quadra, voleibol e xadrez. (grifos nossos)

Em seguida, há no texto uma pseudo-quebra dessa propriedade enumerativa, com a caracterização das duas escolas que funcionam no local. Porém, num segundo momento, percebe-se um distanciamento, decorrente da simples menção ao nome das escolas, sem integrá-las no contexto da Febem. Sabe-se apenas que uma é profissionalizante, outra, responsável pelo ensino fundamental e médio. Esse distanciamento é marcado também com relação aos jovens (internos), que são novamente citados no meio do texto, muito rapidamente: "Os jovens podem escolher" atividades.

O Complexo também tem uma escola profissionalizante e uma escola de ensino formal. A Escola Profissionalizante Marina Vieira de Carvalho Mesquita oferece em suas dependências 31 oficinas, além de coordenar as atividades profissionalizantes realizadas dentro de cada unidade. Já a Escola Oficina Rosmay Kara José é a responsável pelo ensino fundamental e médio. Recebe em suas dependências, os jovens das unidades que não têm salas de aula. Dentro do Complexo também funcionam a Divisão de Saúde, Divisão de Segurança, manutenção, lavanderia e cozinha industrial que atendem grande parte das unidades do Estado.

Ao final do parágrafo, mais uma vez, o relise se utiliza de uma seqüência enumerativa para quantificar as subdivisões de que o Complexo dispõe. Na primeira parte do texto, a Febem se auto-afirma não por sua 
capacidade de reabilitação, mas por dados quantitativos. Caberia perguntar se esses dados, necessariamente, garantem que sua finalidade "regenerativa" (educativa) seja cumprida.

Partindo para a segunda parte do relise, temos três fragmentos, que complementam o trecho anterior, cada um definido por um subtítulo específico. Em "O Prefeito", aparece a única indicação de discurso relatado, com a transcrição de uma fala do diretor do Complexo do Tatuapé, sobre o "estilo diferente de gerenciamento" que implantou na unidade.

\begin{abstract}
O PREFEITO - No comando desta super-estrutura desde abril de 2003, está o diretor de divisão, Celso Vieira. Formado em administração de empresas, com especialização em recursos humanos, o "prefeito" do Tatuapé, como é carinhosamente chamado, implantou um estilo diferente de gerenciamento, valorizando a formação de equipes e treinamento dos funcionários. "Respeitando as características de cada unidade e seguindo um padrão, dei autonomia para que os diretores pudessem trabalhar de acordo com as suas necessidades. Esse foi um dos pontos principais para que as unidades funcionassem de maneira tranqüila durante o ano", explica. Outro fator importante é que o diretor do Complexo começou, há quinze anos, como funcionário de pátio. "Essa experiência do monitor que virou diretor de divisão faz com que os funcionários se sintam mais próximos e o entrosamento com a área técnica é muito maior", conclui Vieira.
\end{abstract}

É importante ressaltar aqui que o texto traz um argumento de autoridade - na pessoa do diretor Celso Vieira - como recurso discursivo, com a finalidade de corroborar a proposta do relise de que a Febem funciona como uma cidade. A frase entre aspas tem como principal função, nesse trecho, explicar, com conhecimento de causa, o motivo do sucesso do "estilo diferente de gerenciamento" da Unidade, fortalecendo a idéia de que a experiência e a autonomia são as peças-chave da qualificação de seus funcionários. Além disso, as referências do prefeito, "formado em administração de empresas, com especialização em recursos humanos", vem reforçar ainda mais sua autoridade no assunto, colocando-o como uma pessoa altamente qualificada para o cargo.

Um fato curioso, ainda, é a referência ao diretor como "Prefeito do Tatuapé, como é carinhosamente chamado". A utilização da voz passiva é uma construção sintática que permite omitir o agente da ação, assim não se sabe quem o nomeia dessa forma. Essa denominação tem o efeito de acentuar ainda mais a idéia de que o complexo é uma cidade. 
No trecho seguinte, enfatiza-se que a instituição tem uma longa história, seja pelo subtítulo do fragmento, seja pela data da fundação, mencionada duas vezes, abrindo e fechando o parágrafo, circularmente.

HISTÓRIA - Em 1902, com o projeto de criação de um instituto disciplinar para jovens infratores, do chefe de polícia de São Paulo, Cardoso de Almeida, o governo do Estado desapropriou a Chácara do Belém e inaugurou a Escola Correcional. A idéia era que lá fossem recolhidos jovens abandonados e pequenos criminosos, que até então ficavam em cadeias com adultos. O primeiro interno chegou à escola em 23 de fevereiro de 1902.

Aqui, a argumentação se sustenta pela utilização de "provas concretas", embasada em fatos comprobatórios. Os dados apresentados são pertinentes e visam a reforçar a capacidade e experiência da Febem, criada por um chefe de polícia, que, há mais de 100 anos, funciona no Estado de São Paulo para "disciplinar jovens infratores".

O último parágrafo, apesar de trazer um subtítulo que, à primeira vista parece estar fora do contexto geral, "SP 450 anos", é o único que irá dar espaço - e apenas aqui - aos internos da Febem. Os adolescentes em questão se tornam, aqui, quase no final, agentes no texto:

SP 450 ANOS - A "cidade" da Febem também irá comemorar os 450 anos da capital paulista, com o $5^{\circ}$ Encontro de Dança de Rua, no dia 25 de janeiro, às 11 horas. São cerca de 300 adolescentes que participam da oficina de Dança de Rua, promovida em várias unidades do Estado pelo Ballet Stagium. Ao final do evento, os participantes cantam parabéns para a cidade com um bolo feito pelos próprios adolescentes do Tatuapé." (grifos nossos)

Ocupando apenas um parágrafo - aliás, o último - a comemoração dos 450 anos de São Paulo acaba se tornando aqui mais um pretexto para divulgar a instituição, sugerindo uma imagem exageradamente positiva e poetizada da Febem e, junto com ela, também do Governo.

Em suma: elaborado do ponto de vista das autoridades, visando a conquistar a simpatia do setor privado, esse relise tem sua progressão temática calcada numa argumentação que se apóia numa metáfora e em dados quantitativos. No texto, os valores conferem diversidade e 
grandiosidade ao Complexo da Febem do Tatuapé. Mais do que divulgar o produto "Febem" em si, o relise divulga a instituição, seus eventos, seus conceitos e suas idéias. A metáfora que associa a Febem a uma cidade resulta no efeito de considerar os jovens infratores como habitantes de um ambiente urbano normal e tranqüilo. Os dois recursos se combinam e percorrem todo o relise, numa progressão que visa persuadir e convencer o destinatário. 
"Liberté, Egalité, Fraternité"

(Liberdade, Igualdade e Fraternidade)

(Lema da Revolução Francesa, 1789)

"Eu estarei vestindo aquele jeans

Que você bem conhece

E o que resta de azul da camisa

Das festas de Abril"

(O Encontro, Roberto Carlos, 2003) 


\subsection{O JEANS COMO IMAGEM POÉTICA}

No terceiro relise, o trabalho persuasivo volta-se para um enfoque mais marcadamente poético. Aqui, a estrutura que nos exemplos anteriores lembrava uma matéria de jornal - com título no estilo manchetado e primeiro parágrafo impactante como um lead - dá lugar a um texto mais elaborado, rico de alusões à década de 70 . O jeans Zoomp, o produto a ser divulgado, se transforma numa proposta plena de sugestões associativas e poéticas, de caráter evocativo.

\section{Black Panther Party - Zoomp Inverno 2004}

Há um perfume dos anos 70 no ar. Apenas um perfume. Influências da estética black \& soul e essências orientais permeiam o Inverno 2004 da ZOOMP. Ícones do espírito de liberdade e igualdade como os Panteras Negras ${ }^{1}$. Angela Davis ${ }^{2}$, Jim Morrison ${ }^{3}$, Janis Joplin ${ }^{4}$, e o mistério do Oriente compõem a fonte de inspiração para um grande evento onde se reúnem ciganos urbanos, cidadãos antenados, nômades de nossos dias. A resultante deste universo pode ser traduzida em uma festa de transformações e de conquistas na qual o poder negro foi determinante, contagiando tendências. Nesta atmosfera, o sexy definitivamente se consagra como alma e sinônimo da marca.

O Jeans é protagonista. Tratado de forma diferenciada, materializa os sonhos e desejos de uma década, surgindo nas mais variadas lavagens e padronagens. Formas que recriam túnicas, kaftans, batas, resgatando detalhes preciosos da cultura pop dos anos 70. O jeans surrado e desbotado - Vintage Stone Washed - revive uma das primeiras lavagens utilizadas pela marca, em 1974. De tonalidade azul clara, quase um délavé, passeia por peças de modelagens não convencionais. O black é apresentado com efeitos desbotados. Uma luz sutil ilumina o conjunto. Calças de modelagem tradicional, jaquetas e batas em sarja com punhos. Ainda o jeans, define a alfaiataria com paletós, casacos e jaquetas em jeans espinha de peixe nos quais texturas simulam o aspecto gasto.

O desejo de reler esses elementos de uma forma nova traduz-se na predominância de vários tons de preto sobrepostos que surgem e simbolizam a diversidade de referencias inspiradoras. É a sobreposição de culturas compondo e alimentando a alma criativa. Aplicações de guizos, moedas, medalhas, penduricalhos e franjas reforçam o espírito de celebração, do ritual. Black Panther Party.

\section{ENJOY the Party.}

1. Organização negra contra a discriminação social mais significativa de todos os tempos.

2. Integrante dos Panteras Negras e ativista política, conhecida internacionalmente por seu engajamento no combate a todas as formas de opressão nos Estados Unidos e outras partes do mundo.

3. Vocalista e compositor da banda norte-americana The Doors, além de autor de vários livros de poesia. Morreu em julho de 1971, aos 27 anos, por overdose, tornando-se ícone de sua geração.

4. Assim como Jim Morrison, marcou a juventude da década de $70 \mathrm{com}$ sua voz inconfundível interpretando blues. Também morreu de overdose, em outubro de 1970. 
Logo no parágrafo inicial, são feitas referências claras aos anos 70 e ao espírito de liberdade e igualdade da época, destacando ícones como "Panteras Negras, Ângela Davis, Jim Morrison, Janis Joplin, e o mistério do Oriente", numa enumeração aparentemente aleatória de nomes e personagens para reforçar o dito espírito dessa década. Mais do que relacionar as influências dos 70 , o texto cria uma contextualização esmaecida dessas "fontes de inspiração" que são as responsáveis pelo "grande evento onde se reúnem os ciganos urbanos, cidadãos antenados, nômades de nossos dias", símbolos de um individualismo marcado por atitudes particulares - a verdadeira forma de liberdade (ser aquilo que se deseja ser) que se refletiria na escolha do jeans anunciado.

Destaca-se aqui, ainda, a combinação escolhida entre substantivos e adjetivos, criando um paralelismo em que a retomada do mesmo sintagma (substantivo mais adjetivo), apoiada em recursos sonoros resulta em amplificação do sentido: "ćigannons + urbannons nômades + de nossos dias". A terceira dupla da série traz uma locução adjetiva, em vez de um simples adjetivo, acentuando espacial e sonoramente a sugestão de ampliação de sentido. Além disso, cabe ressaltar a antítese do primeiro e do último par "ciganos $X$ urbanos" e "nômades X de nossos dias", respectivamente. Os aventureiros atuais sobretudo aqueles de quem o relise parece falar - não são "nômades" em função da luta pela sobrevivência, mas tão somente devido ao gosto pela aventura ou por um modo de vida alternativo. No conjunto, o trio de caracterizações paralelísticas aponta índices da "diferença", da "singularidade" que envolve certas pessoas ou certos grupos. Aqueles que devem ser associados ao produto-tema do texto.

São praticamente seis linhas iniciais de discurso expositivo para se chegar a uma conclusão, no final do fragmento, sobre as novas significações que ganham espaço nessa aparente miscelânea de influências estéticas. $\mathrm{Na}$ verdade, todas as tendências ou personalidades mencionadas são marcadas pela atitude corajosa e diferenciada em relação ao comum dos mortais. Indica-se o combate ou condenação à segregação social, pela menção às reivindicações e conquistas do "poder negro", enquanto "o sexy definitivamente se consagra", a partir da alusão a outros ícones. 
A recorrência do termo "perfume" na primeira linha aponta a sensação olfativa, propondo que, na memória todas as impressões sensoriais se fundem. A mescla entre o perfume, o tempo (a lembrança da década de 70) e os ícones combinam diferentes impressões sensoriais, em imagens sinestésicas, que acentuam a atmosfera poética que envolve $\mathrm{o}$ jeans descrito no relise.

As aliterações de /s/ por todo o parágrafo criam um efeito sonoro que começa em "perfume dos anos 70" até chegar à consagração da marca. Em meio a isso, encontra-se ainda uma alusão à Revolução Francesa ao apresentar "espírito de liberdade e igualdade" da geração dos 70. E, por extensão, de todas as gerações que ousaram ser livres, como fica implícito que a de hoje igualmente seria, se usasse o produto "símbolo dessa liberdade" - de ser e de sentir - que o jeans anunciado representa.

Há um perfume dos anos 70 no ar. Apenas um perfume. Influências da estética black \& soul e essências orientais permeiam o Inverno 2004 da ZOOMP. Ícones do espírito de liberdade e igualdade como os Panteras Negras, Angela Davis, Jim Morrison, Janis Joplin, e o mistério do Oriente compõem a fonte de inspiração para um grande evento onde se reúnem ciganonos urbanonos, ćidadãos antenados, nômades de nossos dias. A resultante deste univers $\underline{\mathbf{s}}$ pode $\underline{\mathbf{s}} \mathrm{s}$ traduzida em uma festa de tranśformações e de conquistas na qual o poder negro foi determinante, contagiando tendências. Nesta atmosfera, o sexy definitivamente se consagra como alma e sinônimo da marca. (grifos nossos)

Passando para o segundo parágrafo, temos uma personificação do "Jeans", escrito em letra maiúscula e transformado em "protagonista" dessa festa com perfume de anos 70 no ar. Além da alusão literal feita na primeira frase, a personificação se dá também pelo fato de "jeans" ser o sujeito do verbo do segundo período, onde se "materializa" como nos sonhos e desejos da década mencionada.

Assim, os ícones que, no fragmento anterior, ditavam os significados que o tecido representava, na época, cedem agora lugar a novas lavagens e padronagens: formas que recriam túnicas, kaftans e batas, calças de modelagem tradicional em jeans surrado e desbotado (Vintage Stone Washed), jaquetas e batas em sarja com punho ou paletós, casacos e 
jaquetas em jeans espinha de peixe. E para criar um efeito coesivo entre tantas alusões aparentemente soltas, o redator abusa de um jogo de palavras com carga poética, recriando um tempo e um espaço para cada uma das tendências de moda descritas. Por exemplo, as túnicas, kaftans e batas "resgatam os detalhes preciosos da cultura pop dos anos 70", enquanto o Vintage Stone Washed "revive uma das primeiras lavagens utilizadas pela marca”. Eis que o jeans conquista seu espaço no campo da intertextualidade!...

Novamente a aliteração de /s/ permeia todo o fragmento, geralmente na terminação das palavras, ecoando o som final de "jeans". Também se encontra assonância da vogal "a" aberta, assim como ecos que lembram a forma de rima. E assim como acontece na recorrência do termo "perfume", no primeiro parágrafo, aqui o efeito poético desencadeador da coesão por reiteração sonora e semântica está na "luz" que "llumina".

\footnotetext{
O Jeans é protagonista. Tratạdo de forma diferencia $\underline{\underline{a}} d a$, materializa $\underline{\underline{a}}$ os sonhos e desejos de uma déca $\underline{\underline{a}} d \underline{\underline{a}}, \underline{\underline{s}}$ urgindo na $\underline{\underline{s}} \underline{\underline{s}}$ mais varia

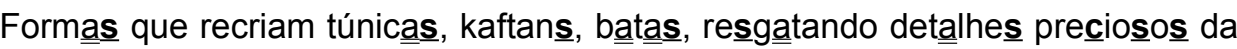
cultura pop dos anos 70 . O jeans surrado e desbotado - Vintage $\underline{\underline{s}}$ tone Washed - revive uma da $\underline{\underline{s}}$ p primeira $\underline{\underline{s}}$ lavagens utilizada

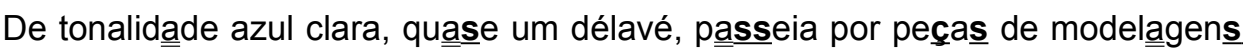
não convencionais. O blạck é apresentândo com efeitos desbotados. Uma luz sutil ilumina o conjunto. Ca $\underline{\underline{a}}$ lças de modelagem tradicional, jaqueta $\underline{\underline{a}}$ e batas em $\underline{\text { sarja }}$ com punhos. Ainda o jeans, define a alfaiataria com paletós, casacos e jaqquetas em jeans espinha de peixe nos quais texturas simulam o aspecto ga
}

Aqui, novamente, o texto faz uso de alusões sensoriais. A maioria delas visuais, mas, também táteis, como por exemplo: "texturas simulam o aspecto de gasto". Essas alusões ecoam as imagens sensoriais presentes no parágrafo anterior.

No último trecho, não há mais referências a grupos e pessoas, nem a cores e modelos do tecido. O que ganha espaço agora é um tipo específico de jeans: o black. É sobre ele, nas várias nuances de preto, que serão feitas as releituras de tudo o que se apresentou sobre os movimentos culturais da década de 70 , numa "sobreposição de culturas compondo e alimentando a 
alma criativa”. Essa sobreposição se evidencia ainda na enumeração das "aplicações que reforçam o espírito de celebração, do ritual" - guizos, moedas, medalhas, penduricalhos e franjas.

Novamente a enumeração - assim como no fragmento sobre lavagens e padronagens - se apresenta de modo particular com dupla função: como elemento persuasivo e, ainda, como um dos elementos coesivos do parágrafo, servindo como ligação entre as diversas tendências resgatadas que se unem para criar a nova coleção de inverno da marca. Essa enumeração causa no texto um efeito de estaticidade, sugerindo uma suspensão da passagem do tempo, já que o jeans seria "eterno".

Dessa forma, como em todo o restante do texto, o autor se prende a um signo da época para sugerir a ambientação que sustenta sua argumentação. A última frase, "ENJOY the Party", é um explícito convite para que o leitor participe dessa nova 'reinvenção' do jeans trazida pela Zoomp para o Inverno 2004, resgatando os conceitos dos anos 70, dos tempos da 'Black Panther Party'. Além dessa associação, fica a referência à festa permanente para os que usam um jeans com tantas qualidades.

A seleção dos verbos também é fundamental na recuperação dessa época, por isso o relise propõe um eixo que percorre verbos significativos: "resgata", "recria”, "revive”, "relê", "reforça”, "permeia”, "compõe”, “consagra”, "define", "materializa" a década de 70.

\footnotetext{
O desejo de reler esses elementos de uma forma nova traduz-se na predominância de vários tons de preto sobrepostos que surgem e simbolizam a diversidade de referencias inspiradoras. É a sobreposição de culturas compondo e alimentando a alma criativa. Aplicações de guizos, moedas, medalhas, penduricalhos e franjas reforçam o espírito de celebração, do ritual. Black Panther Party. (grifos nossos)
}

\section{ENJOY the Party.}

De maneira geral, no relise acima, o jeans está sempre relacionado a ícones reconhecidos por seu público - sejam da música, da moda, da cultura - utilizando a mística do tecido em si como uma espécie de recurso poético metafórico que representaria a miscelânea de idéias e conceitos que vão se constituindo no texto: é peça fundamental para os ídolos da época, depois 
se apresenta em suas lavagens e padronagens, para finalizar como a base para recriações da alma criativa da nova coleção de inverno da Zoomp.

Fugindo ao lugar comum do gênero, mas sem perder as características que o tornam um relise, o texto mistura recursos expressivos e dá espaço à função poética da linguagem para obter determinada atmosfera que resulta em um efeito persuasivo. A possível razão para isso seria a intenção de mostrar que, assim como o relise que o divulga, o jeans Zoomp também tem um diferencial que o destaca dos demais. Decorre disso a forte sugestão implícita: quem o usar, também se sentirá destacado e espacial, quando comparado aos demais. 
"A comunicação é o processo da partição da experiência para que se torne patrimônio comum"

"A sociedade não só continua a existir pela transmissão, pela comunicação, como também se pode perfeitamente dizer que ela é transmissão e comunicação"

(John Dewey, Dicionário de Comunicação. Ed Ática, 1987, p.151) 


\subsection{TECNOLOGIA NO PAPEL}

Pela primeira vez nos relises analisados nos deparamos com um texto técnico, repleto de terminologia específica, voltado para o segmento de telefonia celular. Apesar de esse vocabulário sobre soluções de vídeo para aparelhos celulares não fazer parte do repertório das pessoas em geral, aqui ele se torna pertinente, devido ao público a que se destina. Nesse caso particular, o assessor de imprensa tem total consciência de que os jornalistas que receberão esse relise estão acostumados com o tema e suas especificações técnicas. Caberá a estes últimos o papel de transmitir a informação ao grande público de forma simplificada.

Vivo é a primeira operadora do país a oferecer serviço de vídeo no celular A operadora lança quatro aplicativos para o serviço com tecnologia downloads e streaming para rodar filmes no celular $A$

Se você acha que já sabe tudo sobre celulares, reconsidere. A partir desta semana, a Vivo inaugura uma nova era para a telefonia móvel: a era do vídeo no celular.

A maior operadora de telefonia móvel da América do Sul sai na frente da concorrência e lança no Brasil o serviço de vídeos no celular. São quatro aplicativos veiculados pelo serviço Vivo downloads e baseados na tecnologia brew, com soluções de vídeo downloading e vídeo streaming, disponíveis nas praças onde a operadora atua com a rede CDMA. O processo de desenvolvimento durou seis meses, envolvendo a análise das melhores soluções fornecidas por seis potenciais parceiros tecnológicos, que culminou na escolha da T-Midia, como provedora da solução de vídeo e I-House, na integração com câmeras periféricas.

Os aplicativos serão lançados em série a partir desta semana para inclusão no ambiente de Vivo Downloads, já lançado em março de 2003 pela Vivo. Por isto seguem a tarifação do Vivo Downloads, a partir de $R \$ 0,04$ centavos o Kilobyte em regiões 1XRTT e custo de uma ligação local nas outras regiões. Os serviços de vídeo são compatíveis com aparelhos disponíveis no mercado - LG Life, Motorola T720, Samsung Twist e Toshiba Audiovox.

A partir da solução downloading, o usuário poderá baixar e assistir vídeos no celular. Neste sistema a operadora já estréia com dois aplicativos. O Vídeo On Demand oferece trailers de longa-metragem de grandes estúdios; em breve terá ampliação do menu com filmes de carros, em parceria com a revista Quatro Rodas e vídeo-clips de música. Já a Spicy TV é o canal de vídeos eróticos, com assinatura da Promogard. Para garantir eventuais restrições de acesso, a operadora fornece senha de proteção e a opção de black-list, que bloqueia o acesso ao canal mediante pedido do usuário.

Com a solução de "vídeo streaming", disponível em áreas cobertas com a rede CDMA 1x RTT, não há necessidade de armazenar o vídeo no celular, já que a maior vantagem é a informação em tempo real. Por isso, o streaming é 
direcionado a comportar aplicativos cujo conteúdo precisa de atualização constante. Neste sistema a operadora apresenta o Vídeo Trânsito, um serviço que mostra imagens dos principais pontos da cidade em tempo real, auxiliando o motorista a escolher as melhores vias para trafegar.

Outra novidade é o Vídeo ao Vivo. Com software baixado em um computador mais uma câmera de vídeo compatível ligado a ele (a Vivo indica pelo menos 30 já disponíveis no mercado), o usuário pode fazer monitoramento de imagens em tempo real, para atender às questões de segurança, entretenimento e negócios.

À distância, o cliente poderá por exemplo acompanhar os passos do bebê, as férias dos amigos e dos parentes, o movimento da loja, a fachada da casa, etc.

Para oferecer a melhor relação custo x benefício ao usuário, os aplicativos em streaming são tarifados por assinatura mensal mais Kilobytes trafegados.

Os novos aplicativos chegam para sacudir o mercado. Com tarifas equivalentes a serviços já existentes e terminais disponíveis no mercado em faixa de preço compatível, a Vivo reduz a barreira de entrada e promete popularizar o acesso ao novo serviço.

Logo no título o relise traz uma afirmação de peso ao dizer que a Vivo "é a primeira operadora do país a oferecer serviço de vídeo no celular", chamando a atenção para o pioneirismo da empresa. Na linha fina do texto conhecida também no jornalismo como olho - a afirmativa é reforçada, numa explicação sucinta, porém contendo as principais informações, sobre os quatro lançamentos da operadora. Ou seja, mesmo antes de chegar ao texto propriamente dito o leitor já sabe o que são (aplicativos), como funcionam (tecnologia downloads e streaming), para que servem (rodar filme no celular) e onde é possível usar (celular A) os lançamentos da Vivo.

Vale destacar, ainda, que já nesse pequeno fragmento que apresenta as principais idéias do texto, nos deparamos com uma difusão de competências do novo serviço da operadora, que pode ser atribuído para os mais diversos fins: vida pessoal, profissional, trânsito, entre outros.

Outro ponto importante é o modo como a coesão referencial permeia todo o relise: a Vivo é retomada não só pelo seu nome, mas também pelo hiperônimo de seu ramo de atividade: a operadora - ou ainda segundo o texto: "a maior operadora de telefonia móvel da América do Sul”.

Passando para o primeiro parágrafo, temos uma frase de impacto que busca prender a atenção do jornalista. Apesar de parecer questionar o 
conhecimento do interlocutor, a intenção, na verdade, é enfatizar o ineditismo do serviço e a importância de conhecê-lo.

Se você acha que já sabe tudo sobre celulares, reconsidere.

$\mathrm{Na}$ segunda parte do fragmento - também bastante curta - 0 complemento adverbial "a partir desta semana" ganha destaque, uma vez que inaugura, segundo o texto, "uma nova era para a telefonia móvel". A escolha lexical do substantivo "era", indicando época, enobrece o produto. Ao classificar o mercado antes e depois do "vídeo no celular", pretende destacar a grandiosidade do serviço, colocando a Vivo como precursora de uma tendência mundial de aprimorar os aparelhos celulares. A repetição do termo "era", intencional, resulta numa coesão sonora que acentua a importância dos novos tempos, para os que utilizarem o produto anunciado.

A partir desta semana, a Vivo inaugura uma nova era para a telefonia móvel: a era do vídeo no celular.

Esses dois exemplos, assim como a ausência da preposição em "assistir vídeos" - na primeira linha do quarto parágrafo - mostram que o relise em questão, apesar da terminologia técnica, opta por um registro que, em certos casos, se aproxima do informal, dando uma impressão de "conversa" com o interlocutor. Um dos motivos disso poderia ser, inclusive, amenizar o excesso de especificações técnicas e termos em inglês que muitas vezes apresentam o risco de deixar a leitura truncada.

Mais voltado para o conteúdo, a preocupação em mostrar a supremacia da Vivo em seu segmento permeia ainda o restante do texto, como ilustram os fragmentos que se seguem, nos quais predomina o emprego das formas verbais no presente do indicativo, sugerindo permanência dos recursos apresentados:

A maior operadora de telefonia móvel da América do Sul sai na frente da. concorrência e lança no Brasil o serviço de vídeos no celular.

O processo de desenvolvimento durou seis meses, envolvendo a análise das. melhores soluções fornecidas por seis potenciais parceiros tecnológicos 
Neste sistema a operadora já estréia com dois aplicativos. O Vídeo On Demand oferece trailers de longa-metragem de grandes estúdios; em breve terá ampliação do menu com filmes de carros,

Com a solução de "vídeo streaming", disponível em áreas cobertas com a rede CDMA 1x RTT, não há necessidade de armazenar o vídeo no celular, já que a maior vantagem é a informação em tempo real.

Neste sistema a operadora apresenta o Vídeo Trânsito, um serviço que. mostra imagens dos principais pontos da cidade em tempo real, auxiliando 0. motorista a escolher as melhores vias para trafegar.

Para oferecer a melhor relação custo x benefício ao usuário, os aplicativos em streaming são tarifados por assinatura mensal mais Kilobytes trafegados.

Os novos aplicativos chegam para sacudir o mercado. Com tarifas equivalentes a serviços já existentes e terminais disponíveis no mercado em faixa de preço compatível, a Vivo reduz a barreira de entrada e promete popularizar o acesso ao novo serviço. (grifos nossos)

As palavras escolhidas criam uma progressão temática no texto, pela qual a empresa "cresce" diante do interlocutor, gerando uma imagem positiva da operadora. Estando distribuídos ao longo do relise, esses vocábulos e expressões saltam aos olhos mesmo durante a leitura, destacando conceitos importantes para garantir a boa reputação da Vivo no mercado: pioneirismo, inovação, diferenciais, preços justos e, sobretudo, uma tecnologia ao alcance de todos.

A enumeração dos aparelhos celulares compatíveis com a tecnologia lançada pela Vivo - "LG Life, Motorola T720, Samsung Twiste e Toshiba Audiovox" - aparece para mostrar que qualquer usuário comum pode usufruir do novo serviço. Aqui, a vasta gama de aparelhos visa não apenas a evidenciar a abrangência do seu público, mas também evidencia o fato de que a empresa se relaciona - e bem - com muitas marcas de renome do mercado de telefonia móvel.

O texto reforça ainda essa questão no final, justificando que a empresa oferece a "melhor relação custo x benefício", "com tarifas equivalentes a serviços já existentes" e "terminais disponíveis no mercado em faixa de preço compatível". Mais do que isso, há um comprometimento da Vivo com os usuários de celular, de reduzir a barreira de entrada e "popularizar o acesso ao novo serviço". 
Ao final, o relise descreve ainda detalhadamente cada uma das funções agregadas ao serviço de vídeo no celular, dando exemplos de como utilizá-las e para que finalidades. Esses exemplos práticos sugeridos, inclusive, aparecem como estratégias argumentativas para convencer o interlocutor das vantagens oferecidas pela Vivo, e da pertinência de divulgar a empresa junto ao público leitor.

Podemos dizer então que, de maneira geral, o que se evidencia nesta análise é o efeito persuasivo buscado pelo texto por meio de diferentes recursos, destacando-se entre eles: a mescla de linguagem coloquial com $o$ jargão técnico da área de telefonia móvel, os elementos expressivos acentuando o pioneirismo da empresa e o emprego de formas verbais 
"As armas e os barões assinalados Que, da Ocidental praia Lusitana, Por mares nunca dantes navegados Passaram ainda além da Taprobana, Em perigos e guerras esforçados, Mais do que prometia a força humana, $E$ entre gente remota edificaram Novo Reino, que tanto sublimaram;

E também as memórias gloriosas Daqueles Reis, que foram dilatando A Fé, o Império, e as terras viciosas De África e de Ásia andaram devastando; $E$ aqueles, que por obras valerosas Se vão da lei da morte libertando; Cantando espalharei por toda parte, Se a tanto me ajudar o engenho e arte."

(Luís de Camões, Os Lusíadas. Ed Moderna, 1991, p.76) 


\subsection{PIONEIRISMO VINDO DE PORTUGAL}

Diferente dos demais textos analisados, o próximo relise selecionado não está lançando nenhum produto ou serviço no mercado. Seu caráter é primordialmente institucional, apresentando a empresa e contando um pouco de sua história, conquistas e expectativas. Nesse sentido, chega a dar a impressão de ser uma narrativa de ficção, gênero do qual parece intencionalmente se aproximar. Para relatar todos os fatos relevantes no "quase meio século" da empresa no Brasil, a solução encontrada pelo assessor foi centrar a narração na pessoa de seu fundador, apelando mesmo que subjetivamente - para as raízes imigrantes comuns à maioria da população.

FAMÍLIA D'AVÓ:

UMA HISTÓRIA DE VANGUARDA E SUCESSO

\section{Quase meio século de Brasil colocando o consumidor em primeiro lugar}

Quando Dionísio De Avó chegou ao Brasil, em 1951, vindo de Portugal, o imigrante nem imaginava o sucesso que Ihe aguardava. Hoje, 51 anos depois, ele vê seu sonho, que começou no ramo da panificação, transformarse no D'Avó Supermercados, uma respeitada rede que conta com cinco lojas na Zona Leste de São Paulo e dois hipermercado na região do Alto Tietê. A rede D'Avó figura hoje em oitavo lugar no ranking estadual de supermercados ( $21^{\circ}$ no nacional), com um faturamento bruto de $R \$ 388$ milhões em 2002. E quer crescer!

A história de Dionísio e, por conseqüência, de toda a rede, é pontuada por pioneirismos e ousadia. Em 1955, o imigrante português arriscou-se no ramo de panificação, entregando leite e pão de porta em porta. Cinco anos depois, foi aberta a primeira padaria, no bairro do Butantã. "Depois de estabelecido, mandei vir de Portugal 14 familiares, entre primos e irmãos", lembra o empreendedor. Com a vinda dos parentes, outras cinco padarias foram abertas pela cidade, sempre com total identificação com a comunidade local. "Nossa cultura de atendimento ao consumidor veio dessa experiência vitoriosa no ramo de panificação", conta Martinho Paiva Moreira, diretor comercial do D’Avó e filho de um dos sócios.

No começo da década de 80 , incentivados pela população do conjunto habitacional Cohab, onde os De Avó tinham duas padarias, surgiu a oportunidade de participar da concorrência para a abertura de um supermercado no local. O projeto, audacioso, exigia a venda das seis padarias, a união da família e uma dose extra de ousadia. "Foi uma aventura, porque nossos pais e tios saíram de um ramo que eles conheciam profundamente para ingressar no segmento supermercadista", lembra o diretor comercial Toninho De Avó, da segunda geração da família. "Fiquei um pouco inseguro, mas a nova geração da família me encorajou", confessa Dionísio. Os De Avó ganharam a concorrência e montaram uma loja com $2000 \mathrm{~m} 2$. 
A partir de 1983, com a inauguração da primeira loja em Itaquera, o grupo cresceu, conquistou definitivamente a clientela da região onde se instalou e é referência no segmento. O D’Avó marca presença em outros quatro endereços na Zona Leste - Parque São Lucas (inaugurado em 1986), Guaianazes (1991), São Miguel (1994), Itaim Paulista (1996) - e dois hipermercados na região do Alto Tietê - Suzano (1999), Mogi das Cruzes (2001).

Pioneirismo é a palavra para definir o espírito da família e de seu negócio. O D'Avó foi a primeira loja de varejo totalmente informatizada, da retaguarda ao caixa, inaugurando a automação comercial como ela é conhecida hoje. E isso foi em 1991, na loja de Guaianazes. O conceito de PDV modular foi introduzido no mercado pelo D'Avó em 92. A política de precificação adotada pela rede também é pioneira: os preços dos produtos na gôndola tem excelente visibilidade, deixando claro para o consumidor o preço e a discriminação de cada produto.

Outro grande exemplo de inovação é o Cartão Confiança, criado em 97, o primeiro Smartcard do segmento, que oferece crédito aos clientes do D'Avó e atende hoje mais de 200 mil famílias, agilizando e facilitando o processo de compra e pagamento. E a iniciativa deu tão certo que o D'Avó agora oferece também o Confiança Empresa, um substituto da cesta básica.

Procurando cada vez mais melhorar o atendimento à seus clientes, O D'Avó investe também em eventos internos que promovam o interesse e a participação de seus funcionários para aprimorar a relação com o cliente. Implantação de TeleCurso, Projeto Jovem Cidadão e Desenvolvendo Talentos são algumas das iniciativas da rede. Outra grande preocupação é manter o bom relacionamento que conquistaram junto à comunidade nesses 18 anos de existência realizando regularmente ações sociais nas região em que atua.

E a trajetória de vanguarda dos onze sócios não acabou. Para as duas gerações que atualmente conduzem os negócios, atender bem seus clientes continua sendo o desafio mais importante da rede. Um dos principais dentre os muitos que virão. Porque, na história da família D'Avó, desafio é sinônimo de sucesso.

Na primeira leitura do relise já é possível perceber a intenção de gerar uma empatia do interlocutor com Dionísio De Avó, o imigrante português que veio tentar a sorte em terras brasileiras. O próprio título propõe a identificação do interlocutor com a "Família D'Avó" que, assim como tantas outras famílias de imigrantes, é marcada por uma "história de vanguarda e sucesso". A justificativa para tamanho êxito vem logo abaixo, na linha fina: "Quase meio século de Brasil colocando o consumidor em primeiro lugar".

Assim, o relise parece começar narrando realmente a história do patriarca da família De Avó, que, inclusive, empresta seu sobrenome para designar a empreitada de seus descendentes portugueses no Brasil. Mas a 
narrativa não se sustenta apenas por essa estrutura, apesar de ser pontuada por datas a cada parágrafo. Já no primeiro parágrafo dados numéricos saltam aos olhos em praticamente todas as linhas, combinação que retoma a "vanguarda" e o "sucesso" descritos no título, numa progressão coerente que mapeia o empreendedorismo do Grupo:

\begin{abstract}
Quando Dionísio De Avó chegou ao Brasil, em 1951, vindo de Portugal, o imigrante nem imaginava o sucesso que lhe aguardava. Hoje, $\underline{51}$ anos depois, ele vê seu sonho, que começou no ramo da panificação, transformarse no D'Avó Supermercados, uma respeitada rede que conta com cinco lojas na Zona Leste de São Paulo e dois hipermercados na região do Alto Tietê. A rede D'Avó figura hoje em oitavo lugar no ranking estadual de supermercados ( $\underline{21}^{\circ}$ no nacional), com um faturamento bruto de $\underline{R} \$ 388$ milhões em 2002. E quer crescer!
\end{abstract}

A última frase, traz no ponto de exclamação a expectativa de quem não apenas "quer", mas fará tudo para crescer. Se em "quase meio século" já conquistaram os números descritos, o futuro parece prometer ainda mais.

No segundo parágrafo, mais uma vez ganha espaço a veia narrativa do texto, com seqüências que lembram passagens de livros sobre os imigrantes, seus sonhos, suas raízes e as inúmeras batalhas pessoais e profissionais. Um ponto importante nesse fragmento é que Dionísio - ao mesmo tempo em que está presente no texto, tanto por ser mencionado quanto por apresentar sua própria voz, por meio do discurso direto - acaba por deixar de lado seu caráter individual para envolver o Grupo todo e se transformar em "toda a rede"

\begin{abstract}
A história de Dionísio e, por conseqüência, de toda a rede, é pontuada por pioneirismos e ousadia. Em 1955, o imigrante português arriscou-se no ramo de panificação, entregando leite e pão de porta em porta. Cinco anos depois, foi aberta a primeira padaria, no bairro do Butantã. "Depois de estabelecido, mandei vir de Portugal 14 familiares, entre primos e irmãos", lembra o empreendedor. Com a vinda dos parentes, outras cinco padarias foram abertas pela cidade, sempre com total identificação com a comunidade local. "Nossa cultura de atendimento ao consumidor veio dessa experiência vitoriosa no ramo de panificação", conta Martinho Paiva Moreira, diretor comercial do D'Avó e filho de um dos sócios.
\end{abstract}

Depois de Dionísio, é a vez dos demais integrantes da família, que atualmente comandam a rede, ganharem voz no relise. A descrição dos dois executivos, não apenas pelo nome, mas também segundo a geração a qual 
fazem parte, chega a sugerir a imagem de uma árvore genealógica em cujo topo está Dionísio, seguido abaixo dos 14 irmãos e primos que trouxe para o Brasil no início da década de 60 e os respectivos descendentes que foram ingressando na empresa da família.

Depois de estabelecido, mandei vir de Portugal 14 familiares, entre primos e irmãos", lembra o empreendedor [Dionísio De Avó\}

"Nossa cultura de atendimento ao consumidor veio dessa experiência vitoriosa no ramo de panificação", conta Martinho Paiva Moreira, diretor comercial do D'Avó e filho de um dos sócios.

"Foi uma aventura, porque nossos pais e tios saíram de um ramo que eles conheciam profundamente para ingressar no segmento supermercadista", lembra o diretor comercial Toninho De Avó, da segunda geração da família.

"Fiquei um pouco inseguro, mas a nova geração da família me encorajou", confessa Dionísio.

A recorrente questão da família resulta num forte apelo afetivo ao longo do texto, já que família é um valor, inspira confiança. Podemos entender isso como um recurso persuasivo, que parece envolver os consumidores, propondo que façam parte da família D'Avó. Ou seja: que se tornem consumidores dos produtos vendidos por essa rede.

O parágrafo seguinte marca o "suposto" clímax - recurso muito usado nas narrativas de ficção - da saga da família De Avó, quando chegam ao impasse: vender seis padarias para investir na abertura de um supermercado. Mais uma vez, a "união da família", o incentivo da "população do conjunto habitacional" e uma "dose extra de ousadia" (parte-se aqui do pressuposto de que já haviam sido ousados antes, ao arriscar-se no ramo da panificação) garantiram o sucesso dos De Avó que davam o primeiro passo para se tornar a Rede de Supermercado D'Avó.

No começo da década de 80 , incentivados pela população do conjunto habitacional Cohab, onde os De Avó tinham duas padarias, surgiu a oportunidade de participar da concorrência para a abertura de um supermercado no local. O projeto, audacioso, exigia a venda as seis padarias, a união da família e uma dose extra de ousadia. "Foi uma aventura, porque nossos pais e tios saíram de um ramo que eles conheciam profundamente para ingressar no segmento supermercadista", lembra o diretor comercial Toninho De Avó, da segunda geração da família. "Fiquei um pouco inseguro, mas a nova geração da família me encorajou", confessa Dionísio. Os De Avó ganharam a concorrência e montaram uma loja com $2000 \mathrm{~m} 2$. 
O quarto parágrafo, com poucas marcas narrativas, caracteriza-se basicamente pela enumeração das lojas que fazem parte do Grupo, elencando-as por sua localização e data de abertura. Vale atentar ainda para o fato de que, mais uma vez, explicita-se o local de atuação da empresa - a Zona Leste - onde, segundo o texto, o D'Avó é uma "respeitada rede" e "referência do segmento", conquistando "definitivamente a clientela da região".

\begin{abstract}
A partir de 1983, com a inauguração da primeira loja em Itaquera, o grupo cresceu, conquistou definitivamente a clientela da região onde se instalou e é referência no segmento. O D'Avó marca presença em outros quatro endereços na Zona Leste - Parque São Lucas (inaugurado em 1986), Guaianazes (1991), São Miguel (1994), Itaim Paulista (1996) - e dois hipermercados na região do Alto Tietê - Suzano (1999), Mogi das Cruzes (2001).
\end{abstract}

Os dois próximos períodos são bem marcados no que diz respeito a sua temática, mantendo sempre a linha persuasiva, apoiada no recurso da narração. No primeiro, temos o "pioneirismo" tecnológico da rede. Pela primeira vez no relise o conteúdo ganha o teor referente a área de atuação da empresa, utilizando termos específicos do segmento de varejo (grifos nossos):

Pioneirismo é a palavra para definir o espírito da família e de seu negócio. O
D'Avó foi a primeira loja de varejo totalmente informatizada, da retaguarda
ao caixa, inaugurando a automação comercial como ela é conhecida hoje.
E isso foi em 1991, na loja de Guaianazes. O conceito de PDV modular foi
introduzido no mercado pelo D'Avó em 92. A política de precificação
adotada pela rede também é pioneira: os preços dos produtos na gôndola
tem excelente visibilidade, deixando claro para o consumidor o preço e a
discriminação de cada produto. (grifos nossos)

É interessante notar que a informação de que o D'Avó foi "a primeira loja de varejo totalmente informatizada" não ganha destaque no início do relise, aparecendo apenas no meio do texto. Isso porque o redator aparentemente se ateve à ordem cronológica para envolver o leitor na "narrativa". Só mais adiante é empregado um conjunto de termos específicos - destacados no parágrafo acima - reiterando traços do relise enquanto gênero: o pioneirismo e a eficiência do produto (marca ou empresa) apresentado. Nesse sentido, este relise remete ao eixo predominante precedente: o pioneirismo. 
O mesmo acontece com o Cartão Confiança, no parágrafo seguinte. Ele é um case de sucesso totalmente inédito no segmento, que "atende hoje mais de 200 mil famílias" num sistema de crédito acessível a toda a população. Percebe-se que a intenção é manter a continuidade do texto, sua coerência temática e cronológica; e por que não dizer novas "viradas" narrativas para prender a atenção do interlocutor, à medida que ele vai sendo sutilmente convencido.

Outro grande exemplo de inovação é o Cartão Confiança, criado em 97, o primeiro Smartcard do segmento, que oferece crédito aos clientes do D'Avó e atende hoje mais de 200 mil famílias, agilizando e facilitando o processo de compra e pagamento. E a iniciativa deu tão certo que o D’Avó agora oferece também o Confiança Empresa, um substituto da cesta básica.

O próximo fragmento, apesar de não sugerir uma sucessão cronológica, traz como, em todos os períodos anteriores, uma marca temporal - "nesses 18 anos de existência". Aqui, acentua-se a preocupação temática de mostrar o lado humano da empresa, sua preocupação e comprometimento com a comunidade que sempre a apoiou. Segundo o texto, isso acontece de duas formas: ativamente, pela realização de ações sociais, ou passivamente, pela qualificação de seus funcionários para atender cada vez melhor o cliente D'Avó.

\footnotetext{
Procurando cada vez mais melhorar o atendimento a seus clientes, O D'Avó investe também em eventos internos que promovam o interesse e a participação de seus funcionários para aprimorar a relação com o cliente. Implantação de TeleCurso, Projeto Jovem Cidadão e Desenvolvendo Talentos são algumas das iniciativas da rede. Outra grande preocupação é manter o bom relacionamento que conquistaram junto à comunidade nesses 18 anos de existência realizando regularmente ações sociais na região em que atua.
}

No último parágrafo, os vocábulos "vanguarda" e "sucesso" são retomados - um abrindo e outro fechando o fragmento - para reforçar o comprometimento da rede com seus clientes, desde a chegada do fundador de Portugal até os desafios que o futuro reserva.

E a trajetória de vanguarda dos onze sócios não acabou. Para as duas gerações que atualmente conduzem os negócios, atender bem seus clientes continua sendo o desafio mais importante da rede. Um dos principais dentre os muitos que virão. Porque, na história da família D'Avó, desafio é sinônimo de sucesso. 
Assim como nas narrativas de ficção, a história da família D'Avó termina com um desfecho aberto, dentro do qual permanece a perspectiva da escrita de muitos outros relises sobre os feitos de Dionísio e seus descendentes.

De maneira geral, o relise se utiliza do recurso narrativo e da coloquialização da linguagem - como por exemplo no primeiro parágrafo, ao usar "Ihe aguardava" no lugar de "o aguardava" - buscando um efeito persuasivo que chega de forma branda ao interlocutor, como se o assessor de imprensa estivesse interessado apenas em passar adiante essa "história de vanguarda e sucesso". O apelo narrativo, a mescla de registros e a ênfase na eficiência e pioneirismo da empresa ilustram de que modo o relise, além de lançar algo novo, também pode ser utilizado para consolidar a marca de uma empresa, ampliando seu alcance. 
CAPÍTULO 4 
"Os fumantes estão entre os maiores imbecis do século, ao lado dos que não conhecem música e dos que ignoram os computadores".

(Kin Jong II, tirano coreano)

"O tabaco é a paixão das pessoas honestas e quem vive sem fumo não é digno de viver".

(Don Juan de Molière, fala da primeira cena, do primeiro ato da peça) 


\section{CAPÍTULO 4}

\section{CASE GNT: OBSERVAÇÃO DOS RESULTADOS NA MÍDIA}

Para entender o objetivo do relise, consideramos que, além das análises, seria preciso observar os resultados pós-divulgação. Como já foi dito, depois de redigido, o relise é enviado para os jornalistas. Isso pode ser feito individualmente, de forma personalizada, ou para um conjunto de jornalistas selecionados por segmento ou atuação, o chamado "mailing" de imprensa. Em seguida, os que recebem o texto passam a divulgar a proposta do relise em seus respectivos órgão de divulgação.

Para ilustrar este processo, selecionamos um case do canal de televisão por assinatura GNT. O relise a ser analisado abaixo serviu para a divulgação da estréia de um documentário inédito em sua programação. $\mathrm{Na}$ seqüência, apresentamos alguns recortes publicados na imprensa - incluindo também o valor estimado do espaço na mídia, caso ele fosse pago - que demonstram as variadas formas como essa divulgação repercutiu nos veículos de todo o país.

\section{Era Uma Vez Um Fumante estréia no GNT}

Estréia no próximo dia 31/05, Dia Mundial de Luta Contra o Tabaco, às 21h, o documentário inédito Era Uma Vez Um Fumante. Dirigido por Andrés Jarach, o programa mostra a trajetória de Thomas B. em seu primeiro mês como exfumante.

Diagnosticado como nível 4 no teste de dependência física Fagerström, o ponto de partida para essa mudança está calcado no fascínio do protagonista pelos personagens de Clint Eastwood nos clássicos filmes de faroeste, onde a indefectível cigarrilha é presença constante em todas as cenas do "mocinho". Os flashes dos feitos heróicos da personagem em sua mente, cada vez mais, fazem a vontade de fumar ser crescente e Thomas lança uma pergunta a si próprio: "Por que parar de fazer uma coisa que faço tão bem?".

Junto a isso, a jornada começa com uma dualidade que salta aos seus olhos. De um lado, lendo uma matéria jornalística, ele se depara com uma declaração do tirano coreano Kim Jong II que diz: "Os fumantes estão entre os maiores imbecis do século, ao lado dos que não conhecem música e dos que ignoram os computadores". Do outro, uma fala da primeira cena, do primeiro ato de Don Juan de Molière: "O tabaco é a paixão das pessoas honestas e quem vive sem fumo não é digno de viver".

Para um fumante de peso como Thomas, que consumia o equivalente a doze mil injeções intravenosas de nicotina mensalmente - o que compreende 40 cigarros ao dia - continuar seguindo uma vida envolta em fumaça parece ser a opção mais prazerosa. "Tornar-se abstêmio é fácil, seguir abstêmio é que é 
realmente difícil", diz ele. Mas com a ajuda de um time de especialistas, entre eles cardiologistas, nutricionistas, psicólogos e até hipnoterapeutas, a batalha contra o fumo é iniciada.

O documentário mostra ainda experiências laboratoriais com cobaias, os níveis de dependência do cigarro relacionado a cocaína e heroína, as predisposições que fazem um indivíduo se tornar dependente, e monta um verdadeiro arsenal de chicletes de nicotina, inaladores, exercícios diários e uma dieta balanceada a base de proteínas e frutas como armas no combate ao vício.

Abre o texto uma referência à data de estréia do documentário - Dia Mundial da Luta Contra o Tabaco - que, mais do que sentido explicativo, funciona como um chamariz para a importância de sua exibição no exato dia 31 de maio. Ainda no primeiro parágrafo, a palavra "inédito" qualifica o programa, reforçando a vantagem que ele levaria sobre as demais atrações que não estão indo pela primeira vez ao ar na televisão, naquele dia, naquele horário. Como em outros relises analisados, também aqui se valoriza o pioneirismo.

A citação do nome do diretor, na segunda oração, também reforça a importância do programa, baseando-se num argumento de autoridade, ao citar o documentarista francês. Por outro lado, no caso do ator o sobrenome é suprimido, sendo apresentado ao público apenas como Thomas B., dando a sugerir que ele é apenas uma pessoa comum, tentando largar o vício do cigarro.

Fechando o fragmento, a frase que resume o conteúdo do programa, o vocábulo "ex-fumante" se destaca pela escolha lexical. Ao invés de dizer que o programa traz o primeiro mês de Thomas B. "tentando abandonar o cigarro", "lutando contra seu vício", ou qualquer outra expressão que explique a complexidade de sua "missão", definí-lo como "ex-fumante" já deixa transparecer que o desafio foi cumprido - em contrapartida ao restante do relise, que vai apresentando ao leitor as dificuldades enfrentadas pelo protagonista.

No parágrafo seguinte, há uma alusão aos filmes de faroeste, tornados antológicos pelos papéis interpretados por Clint Eastwood. Adjetivos como "clássicos" filmes, "indefectível" cigarrilha e feitos "heróicos" vêm reforçar o dito fascínio do protagonista Thomas B. pelas "cenas de 
mocinhos" que se tornaram marca registrada do cinema hollywoodiano no gênero western. E, também, de certas propagandas de cigarro.

No início da segunda oração, a palavra "flashes" chega a despertar uma sensação visual: ao ler o trecho, é possível criar mentalmente os fashbacks de cenas de Clint Eastwood em suas aventuras no faroeste. A cigarrilha, sempre presente, é marca registrada do mocinho, representando todo o glamour dos personagens - aliás, durante muitos anos esse foi o papel do cigarro nas telas, do cinema e também da televisão, até ser considerado o vilão da saúde.

\begin{abstract}
(...) o ponto de partida para essa mudança está calcado no fascínio do protagonista pelos personagens de Clint Eastwood nos clássicos filmes de faroeste, onde a indefectível cigarrilha é presença constante em todas as cenas do "mocinho". Os flashs dos feitos heróicos da personagem em sua mente, cada vez mais, fazem a vontade de fumar ser crescente e Thomas lança uma pergunta a si próprio: "Por que parar de fazer uma coisa que faço tão bem?".
\end{abstract}

Ao final do fragmento, uma nova voz se apresenta no texto. É do próprio protagonista que, em meio a todo o discurso anti-tabagismo, se questiona sobre a necessidade de parar de fumar. Uma afirmação, "disfarçada" de pergunta, que traz um caráter ambíguo e irônico para o texto, já que, mesmo disposto a abandonar o cigarro, ele ainda tenta apresentar um lado positivo para o seu vício.

A resposta para a retórica pergunta vem logo abaixo, novamente numa clara intertextualidade que traz para o relise duas citações antagônicas:

\footnotetext{
De um lado, lendo uma matéria jornalística, ele se depara com uma declaração do tirano coreano Kim Jong II que diz: "Os fumantes estão entre os maiores imbecis do século, ao lado dos que não conhecem música e dos que ignoram os computadores". Do outro, uma fala da primeira cena, do primeiro ato de Don Juan de Molière: "O tabaco é a paixão das pessoas honestas e quem vive sem fumo não é digno de viver".
}

Contextualizando as personalidades acima citadas no relise, Kim Jong II é o líder da República Popular Democrática da Coréia do Norte, uma ditadura socialista rigidamente centralizada, que nos últimos anos vem liderando uma forte campanha antitabaco no país, proibindo, inclusive, o 
cigarro nas universidades. Já Molière (Jean-Baptiste Poquelin), um dos mais importantes autores teatrais da França no século XVII, que figura entre os mestres da comédia satírica, apresenta um ditirambo sobre o tabaco usando para isso o marcante personagem Don Juan.

Surge um embate entre a visão do dirigente político e o ponto de vista do personagem que é a própria encarnação da sedução. A classe artística, por muito tempo, foi a grande disseminadora do fumo, sinônimo de classe e prestígio antigamente, chegando até a ser considerado pela personagem mais famosa de Molière como "a paixão das pessoas honestas". Ele vai ainda mais longe, dizendo que "quem vive sem fumo não é digno de viver", numa afirmação que contraria a concepção contemporânea do tabaco no mundo e também nas artes, nas últimas décadas. É o tirano Kin Jong II quem traz a atual visão dos fumantes, pelo menos entre a mídia e demais veículos de massa - já que o fumo segue com seus milhões de adeptos pelo mundo -, comparando-os com "os que não conhecem música" e os "que ignoram os computadores", opção considerada por ele como aquela dos "maiores imbecis do século".

Temos então, de um lado, a crítica ao tabagismo, vinda um um autoritário líder comunista; e, do outro, uma ode ao cigarro na fala do eterno sedutor da literatura mundial. Mais uma vez, o tabaco se mostra, assim como nos "clássicos filmes de Hollywood", uma referência nas manifestações artísticas-culturais, difundido durante anos pelo cinema, pelo teatro e pela literatura, e que agora vem sofrendo o impacto de uma ativa luta no mundo todo.

Voltando ao fragmento, o discurso direto das figuras citadas funciona como uma espécie de teatralização da fala de ambos, preservando a integridade do que foi dito e garantindo uma carga de subjetividade que produz efeito de sentido de verdade, nessa dualidade.

No parágrafo seguinte, mais uma vez, o personagem central ganha voz em outra afirmação cheia de ironia e ambiguidade, gerando um certo tom de descontração no texto:

"Tornar-se abstêmio é fácil, seguir abstêmio é que é realmente difícil", diz ele. 
Para fortalecer o tom de seriedade ao documentário, o restante do texto traz diversas referências técnicas que denotam o comprometimento científico das gravações.

\footnotetext{
Diagnosticado como nível 4 no teste de dependência física Fagerström, o ponto de partida para essa mudança (...)

Para um fumante de peso como Thomas, que consumia o equivalente a doze mil injeções intravenosas de nicotina mensalmente - o que compreende 40 cigarros ao dia - continuar seguindo uma vida envolta em fumaça parece ser a opção mais prazerosa.

O documentário mostra ainda experiências laboratoriais com cobaias, os níveis de dependência do cigarro relacionado a cocaína e heroína, as predisposições que fazem um indivíduo se tornar dependente, (...)
}

No segundo fragmento, o uso de comparativos numéricos - elemento tão presente em relises já analisados - amplifica ainda mais o vício de um "fumante de peso", como foi considerado Thomas B. pelo redator do relise. Falar em "12 mil" injeções de nicotina sem dúvida impactam mais o leitor do que os "40 cigarros" diários, equivalentes. Em contrapartida a dados tão precisos, o texto brinca com um elemento poético ao sugerir o prazer que existe numa "vida envolta em fumaça".

O uso de enumerações também é um recurso lingüístico que busca dar sobriedade ao projeto do documentário, mostrando que ele conta com a colaboração de uma completa equipe de médicos e oferece uma vasta gama de opções para quem quiser largar o vício do cigarro. Aqui, ao invés da suposta simples trajetória do primeiro mês como ex-fumante, Thomaz B. se prepara efetivamente para uma "batalha contra o fumo", precisando de toda ajuda possível para largar o cigarro.

\footnotetext{
Mas com a ajuda de um time de especialistas, entre eles cardiologistas, nutricionistas, psicólogos e até hipnoterapeutas, a batalha contra o fumo é iniciada.

O documentário mostra ainda experiências laboratoriais com cobaias (...) e monta um verdadeiro arsenal de chicletes de nicotina, inaladores, exercícios diários e uma dieta balanceada a base de proteínas e frutas como armas no combate ao vício.
}

Um último destaque, no parágrafo final, para a comparação entre o cigarro e outras drogas no que diz respeito a dependência física. Longe dos 
holofotes que marcaram o glamour das cigarrilhas no cinema, hoje o fumante se depara com pesquisas que os colocam no mesmo patamar dos usuários de cocaína ou heroína, todos "dependentes" de substâncias químicas consideradas malignas.

(...) os níveis de dependência do cigarro relacionado a cocaína e heroína, as predisposições que fazem um indivíduo se tornar dependente (...)

O tom irônico permeia todo o relise, usando para isso, principalmente, o papel do cinema por difundir o hábito. $O$ texto traz ainda um aspecto narrativo: conta-se a vida do personagem que toma uma decisão e muda de vida. No entanto, trata-se de vida real, é um documentário, o que sinaliza que esse é mais um recurso que visa ao efeito persuasivo. Outras formas de persuasão utilizadas são os discursos diretos - muitas vezes apelativos e, até, antagônicos - e os argumentos baseados em conhecimento científico como recurso persuasivo. Esses recursos nos fazem lembrar de procedimento similar, no relato da família De Avó.

Não incluímos nessa análise as considerações acerca da imagem de divulgação e do texto que indica como acessá-la em alta definição na Sala de Imprensa do GNT. Nem para o rodapé de serviços do programa, que tem um papel exclusivamente informativo de relacionar os dias e horários da exibição do documentário.

Concluindo, vemos que o relise se estrutura em torno de um jogo de oposições: voz do redator $x$ voz do personagem, opinião de Kin Jong II x opinião de Don Juan, apelo do dever x apelo do prazer (vício). E em torno dessa dualidade, o texto cresce progressivamente do parágrafo 1 ao 4 . No $5^{\circ}$ e último, há uma mudança de tom, próximo aos dos artigos de divulgação científica. Neste ponto, não pode haver dúvida nem contradição: todo o espaço deve ser reservado à verdade científica.

Passemos para a segunda etapa do processo: a verificação de como esse relise foi recebido e aproveitado pela mídia. Selecionamos alguns exemplos da repercussão desse texto em grandes veículos da imprensa 
brasileira, lembrando que, nesse caso, especificamente, não houve nenhum tipo de contato entre o assessor e os jornalistas, a não ser o envio do relise para um mailing especializado na editoria de televisão.

O retorno mais freqüente nesse tipo de divulgação indiscriminada e generalizada são os registros pontuais em seções e colunas que trazem os destaques da programação diária das emissoras de tv por assinatura. É o que acontece nos recortes de 1 a 6 , apresentados a seguir. Os trechos em negrito, nas transcrições, apresentam palavras ou frases retiradas ou transcritas do relise divulgado.

A título de curiosidade, vale atentar para o item "valor" indicado no cabeçalho. Ele é calculado de acordo com a média de custo de um anúncio por centimetragem em cada um dos veículos publicados, que, por sua vez seguem tabelas de preços elaboradas de acordo com sua tiragem e circulação. 
Recorte 1

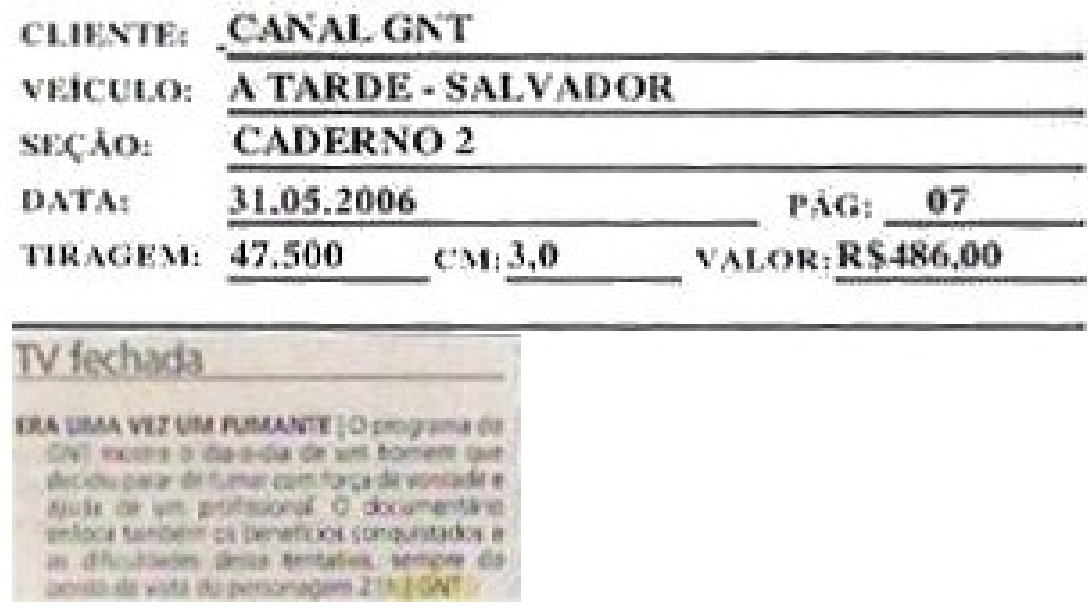

Era Uma Vez Um Fumante - O programa do GNT mostra o dia-a-dia de um homem que decidiu parar de fumar com força de vontade e ajuda de um profissional. $\mathrm{O}$ documentário coloca também os benefícios conquistados e as dificuldades na trajetória vivida pelo personagem. 21h/GNT.

Nesse primeiro recorte, retirado da seção com indicações de programação para TV fechada do jornal A Tarde, de Salvador, Bahia, temos um resumo bastante sucinto do documentário pinçando os principais pontos do relise, mas sem oferecer nenhum aprofundamento ou explicação sobre eles. A proposta aqui é apenas mostrar rapidamente o conteúdo do programa, para que os leitores tenham uma idéia do que será apresentado. 


\section{Recorte 2}

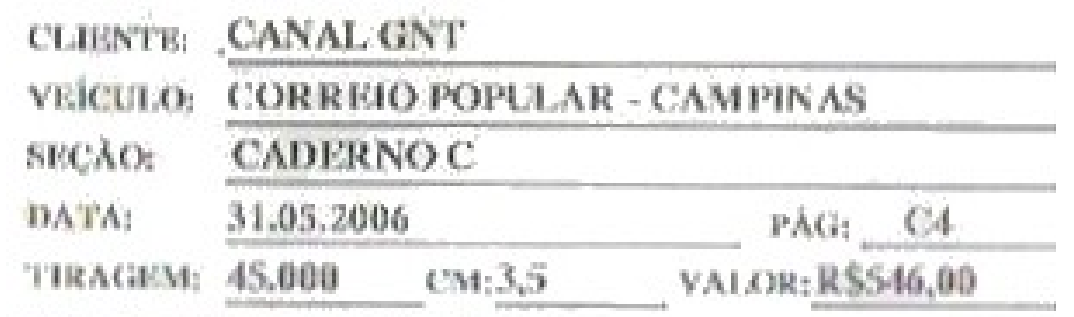

\section{GNT traz documentário}

inédito sobre tabagismo

O canal GNT estrelia hoje,

quando se cornumora o Di

Mundial de Luta Contra o

Tabaco. As 2Lh, o documentário

ined to Era Una Vez Um

Fornante da Anitik larark

GNT traz documentário inédito sobre tabagismo

O canal GNT estréia hoje, quando se comemora o Dia Mundial da Luta Contra o Tabaco, às 21h, o documentário inédito Era Uma Vez Um Fumante, de Andrés Jarach.

Assim como no primeiro exemplo, temos na notícia do Correio Popular de Campinas, São Paulo, um registro curto, dando apenas um breve serviço do documentário: título, assunto, dia e horário. Porém, nesse segundo caso, ao invés de descrever o conteúdo do programa, optou-se apenas por fazer a referência ao dia de exibição (Dia Mundial da Luta Contra o Tabaco) e ao diretor Andrés Jarach, pista para cinéfilos que o conheçam. 
Recorte 3

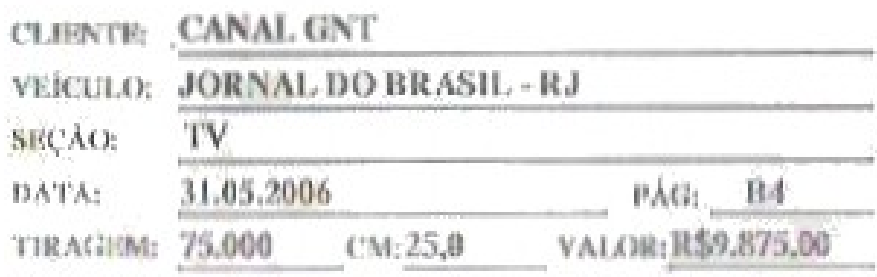

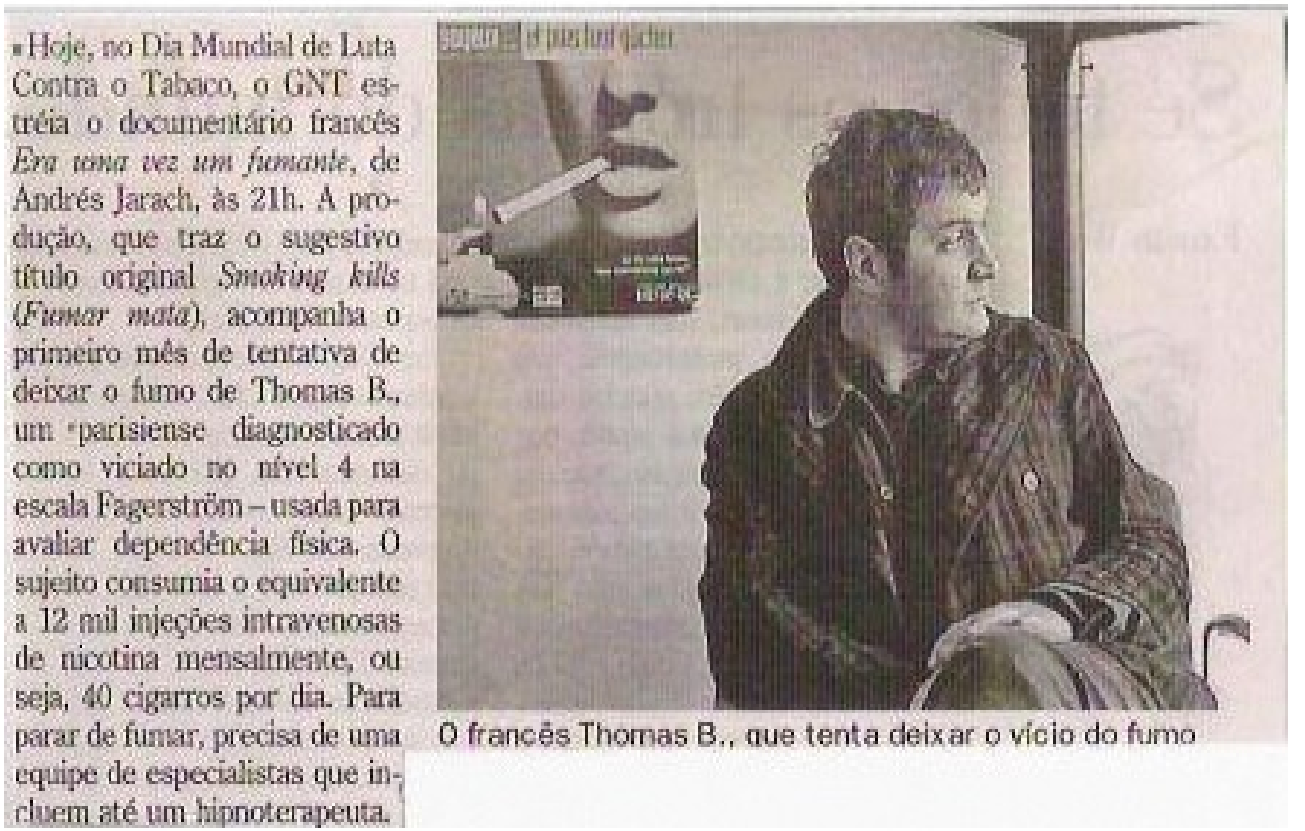

Hoje, no Dia Mundial de Luta Contra o Tabaco, o GNT estréia o documentário francês Era Uma Vez Um Fumante, de Andrés Jarach, às $21 \mathrm{~h}$. A produção, que traz o sugestivo título original Smoking Kills (Fumar Mata), acompanha o primeiro mês de tentativa de deixar o fumo de Thomas B., um parisiense diagnosticado como viciado no nível 4 na escala Fagerström - usada para avaliar dependência física. $O$ sujeito consumia o equivalente a 12 mil injeções intravenosas de nicotina mensalmente, ou seja, $\mathbf{4 0}$ cigarros por dia. Para parar de fumar, precisa de uma equipe de especialistas que incluem até um hipnoterapeuta.

A partir desse recorte, os registros aumentam de tamanho, ganham mais conteúdo e são ilustrados com a foto divulgada no relise. No exemplo acima, do Jornal do Brasil, Rio de Janeiro, é interessante notar que, apesar de ter feito uma pesquisa paralela sobre o documentário (já que cita o nome do programa em inglês, o que não foi divulgado no texto), as informações complementares utilizadas pelo jornalista parecem ser retiradas do relise. 
Basicamente ele empresta do texto os dados mais científicos relacionados ao diagnóstico na escala Fagerström e ao que equivalia $o$ consumo do cigarro em nicotina. $\mathrm{O}$ que mais evidentemente comprova a utilização do relise como fonte é o trecho final "até um hipnoterapeuta", numa construção similar à do texto, utilizando o advérbio "até" para amplificar a grande lista de especialistas que fazem parte do projeto de Thomas B.

Neste caso, o apelo ao possível espectador é mais específico do que nos dois casos anteriores: classifica como "sugestivo" o título original e aponta dados que permitem ao público ter uma idéia mais ampla do documentário. 


\begin{tabular}{|c|c|c|}
\hline CLIENTE: & CANAL GNT & \\
\hline VEICULO: & ESTADO DE MINAS - BH & \\
\hline SECÃO: & CULTURA & \\
\hline DATA: & 31.05 .2006 & PAG: \\
\hline TIRAGEM: & 75.740 CM: 20.0 & OR: R\$5.640,00 \\
\hline
\end{tabular}
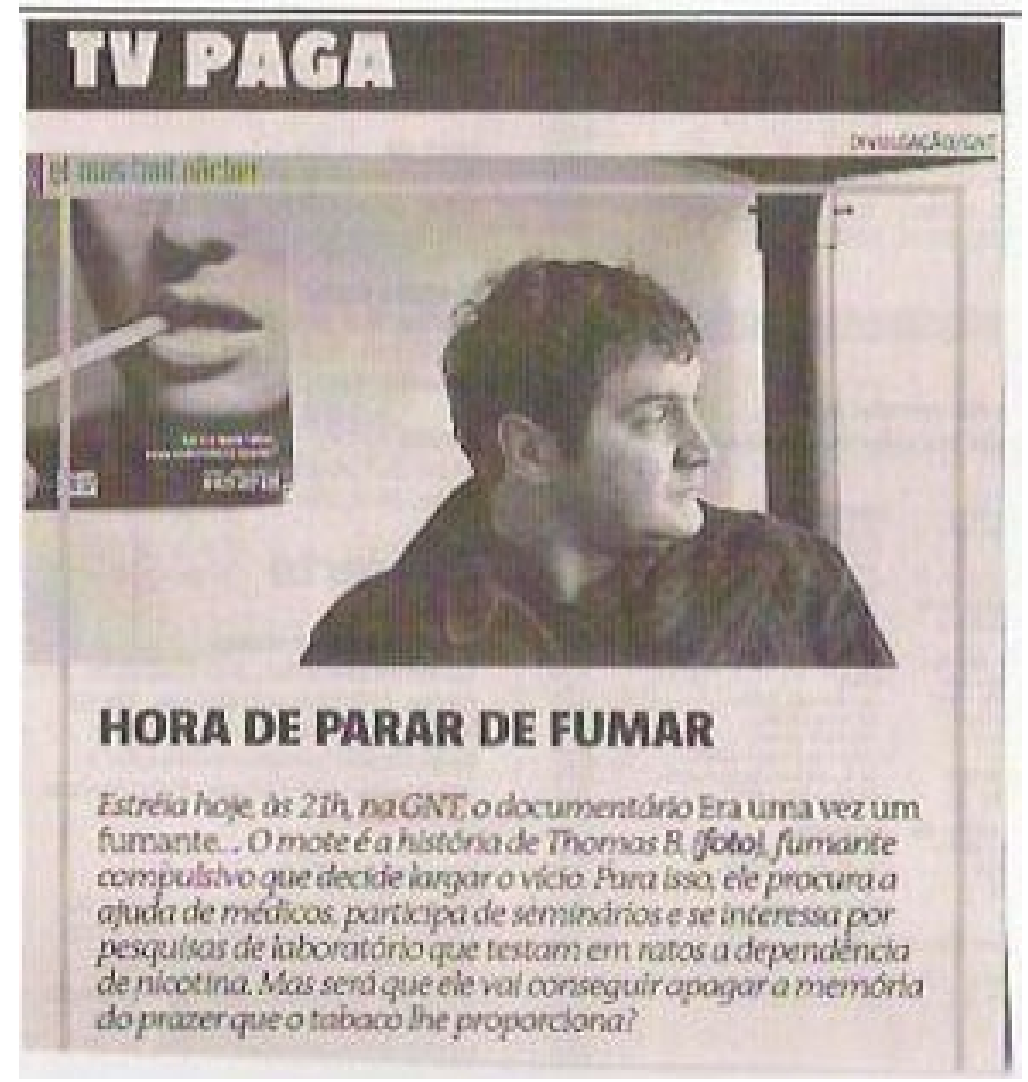

\section{Hora de Parar de Fumar}

Estréia hoje, às 21h, na GNT, o documentário Era Uma Vez Um Fumante. O mote é a história de Thomas B. (foto), fumante compulsivo que decide largar o vício. Para isso ele procura a ajuda de médicos, participa de seminários e se interessa por pesquisas de laboratório que testam em ratos a dependência de nicotina. Mas será que ele vai conseguir apagar a memória do prazer que o tabaco lhe proporciona?

Esse recorte do Estado de Minas de Belo Horizonte, Minas Gerais, traz duas marcas bem distintas dos demais exemplos apresentados até agora. Apesar do rotineiro serviço dia/hora/título/sinopse, nesse caso o título 
- "Hora de parar de fumar" - da notícia ganha mais impacto do que apenas citando a exibição do documentário.

Além disso, uma interrogação arremata o texto, criando o efeito de suspense. Mais do que isso: a frase final - calcada nas duas declarações de Thomas B. divulgadas no texto - dá um ar de dúvida, deixando o leitor na expectativa de saber se o personagem realmente vai conseguir largar o vício do cigarro, e despertando nele o desejo de ver o documentário. 
Recorte 5

\begin{tabular}{|c|c|}
\hline $\begin{array}{l}\text { CLIFNTR: } \\
\text { veiculo: }\end{array}$ & $\begin{array}{l}\text { CANAL,GNT } \\
\text { GAZITA DO POVO-CURITIBA }\end{array}$ \\
\hline $\sec i(x)$ & CADERNOG \\
\hline DATA: & 28.05 .2006 \\
\hline TIR.:B: & 105.000 c"s:24,0 \\
\hline
\end{tabular}

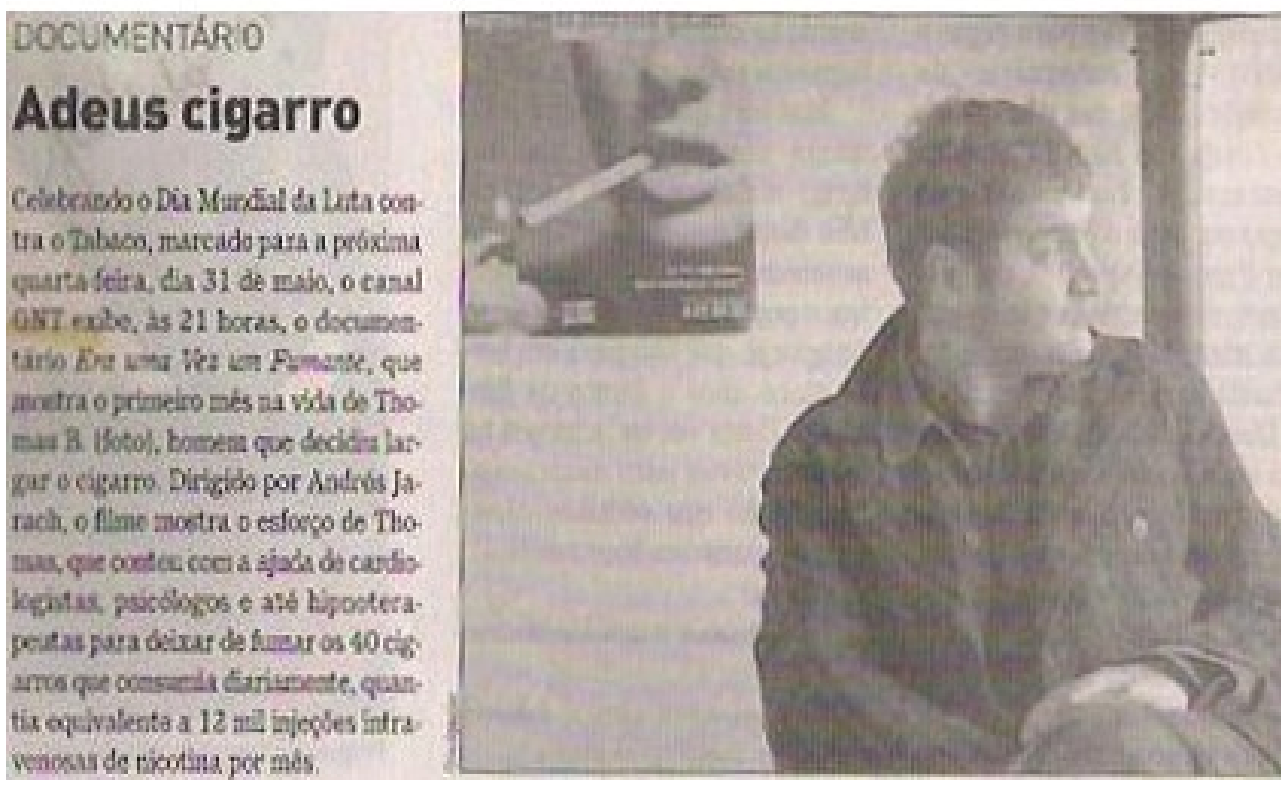

Adeus cigarro

Celebrando o Dia Mundial da Luta Contra o Tabaco, marcado para próxima quarta-feira, dia 31 de maio, o canal GNT exibe, às 21 horas, o documentário Era Uma Vez Um Fumante, que mostra o primeiro mês na vida de Thomas B. (foto), homem que decide largar o cigarro. Dirigido por Andrés Jarach, o filme mostra o esforço de Thomas, que conta com a ajuda de cardiologistas, psicólogos e até hipnoterapeutas para deixar de fumar os 40 cigarros que consumia diariamente, quantia equivalente a 12 mil injeções intravenosas de nicotina por mês.

Assim como no recorte anterior, a notícia da Gazeta do Povo de Curitiba, Paraná, aposta num título impactante: "Adeus cigarro". Pincelando detalhes sobre o documentário, como o mote principal e a direção, faz-se clara a alusão ao relise no segundo parágrafo, com a transcrição dos dados sobre o consumo diário de cigarro do personagem e seu equivalente em injeções de nicotina, sem contar a menção aos especialistas, destacando-se novamente aqui "até" os hipnoterapeutas. 
Recorte 6

$\begin{array}{ll}\text { CLIENTE: } & \frac{\text { CANAL GNT }}{\text { OSUL-PORTO ALEGRE }} \\ \text { vEICULO: } & \frac{\text { MAGAZNE }}{\text { SECAO: }} \\ \text { DATA: } & \frac{31.05 .2006}{70.000} \text { PAG: } \frac{11}{10.5} \text { VALOR:R } \$ 1.963 .00\end{array}$

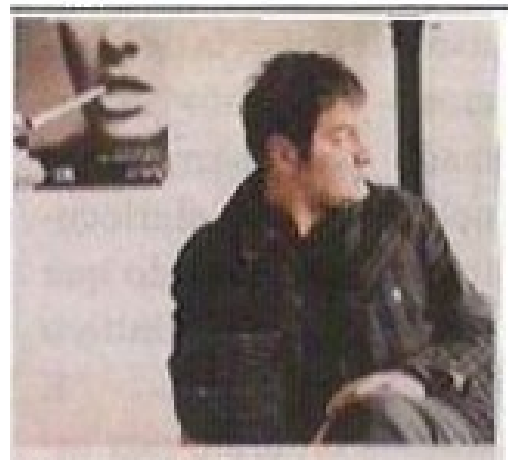

"Era uma Vez

um Fumante"

Detrat bole no Dis Mndar de isa Can-

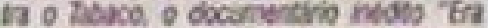

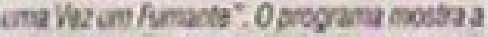

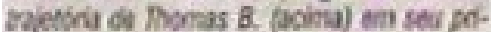

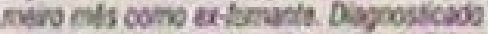

como nuted 4 ro teste de dependhou fsica.

o ponto de partida para essa mudinca esta

caicado no lascinio do protegonstá pelos.

personagens de Clint Eastwood nos class.

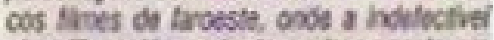

cogriba este constantenente prosecte en.

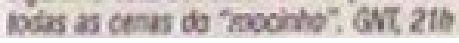

Estréia hoje, no Dia Mundial de Luta Contra o Tabaco, o documentário inédito "Era Uma Vez Um Fumante". O programa mostra a trajetória de Thomas B. (acima) em seu primeiro mês como ex-fumante. Diagnosticado como nível 4 no teste de dependência física, o ponto de partida para essa mudança está calcado no fascínio do protagonista pelos personagens de Clint Eastwood nos clássicos filmes de faroeste, onde a indefectível cigarrilha está constantemente presente em todas as cenas do "mocinho". GNT, 21 horas.

No exemplo do jornal O Sul, de Porto Alegre, Rio Grande do Sul, a utilização do relise acontece não apenas como referência. Excluindo a primeira frase, que foi ajustada para o dia da exibição, o restante do texto foi integralmente transcrito do relise, passando apenas por uma edição do jornalista para retirar o trecho de interesse (linhas 3 a 9 do relise).

No caso deste veículo, percebe-se a menção ao filme de Clint Eastwood, dado ausente nos exemplos anteriores. Ela se alonga apontando 
dados glamurosos da "indefectível cigarrilha", diferentemente das outras opções, num trecho retirado integralmente do relise. 
Recorte 7

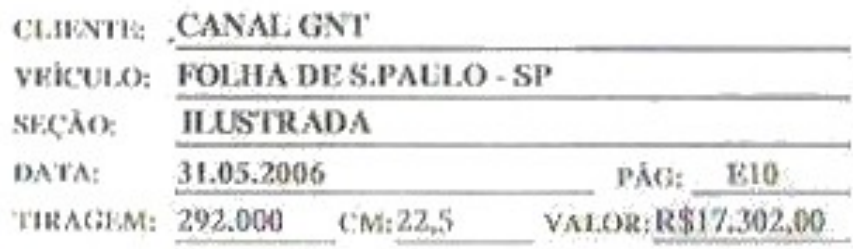

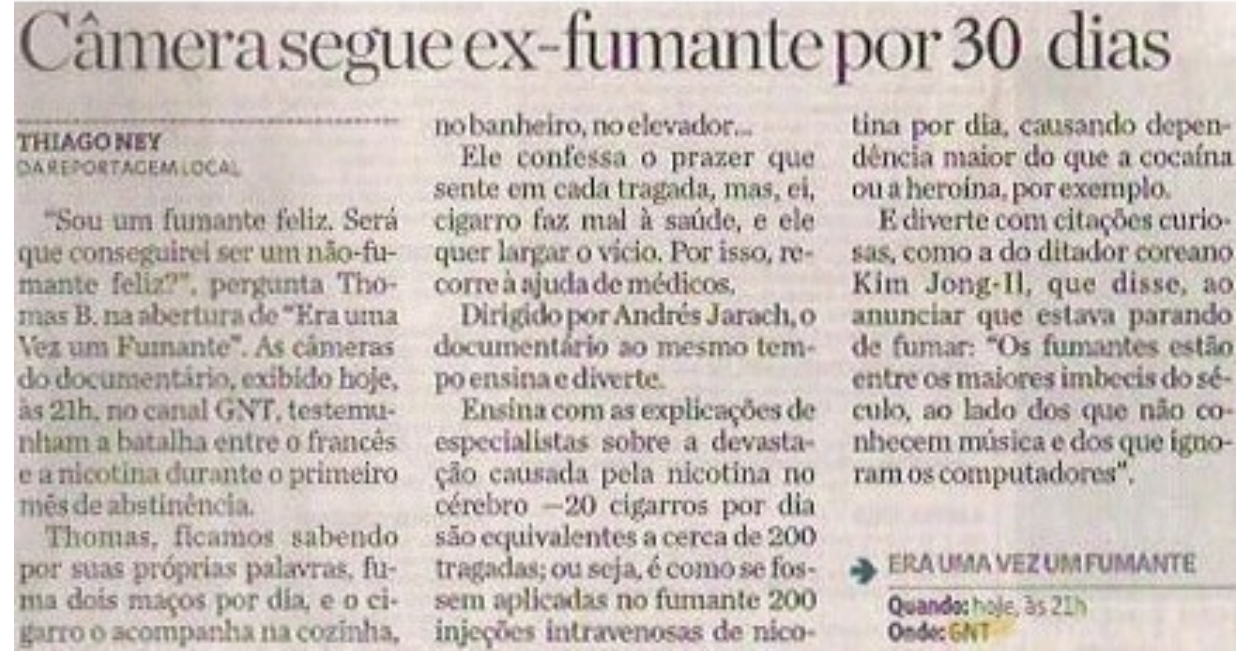

Câmera segue ex-fumante por 30 dias

"Sou um fumante feliz. Será que conseguirei ser um ex-fumante feliz?", pergunta Thoma B. na abertura de "Era Uma Vez Um Fumante". As câmeras do documentário, exibido hoje, às $21 \mathrm{~h}$, no canal GNT, testemunham a batalha entre o francês e a nicotina durante o primeiro mês de abstinência.

Thomas, ficamos sabendo por suas próprias palavras, fuma dois maços por dia, e o cigarro o acompanha na cozinha, no banheiro, no elevador...

Ele confessa o prazer que sente em cada tragada, mas, ei, cigarro faz mal à saúde, e ele quer largar o vício. Por isso, recorre à ajuda de médicos.

Dirigido por Andrés Jarach, o documentário ao mesmo tempo ensina e diverte. Ensina com as explicações de especialistas sobre a devastação causada pela nicotina no cérebro - 20 cigarros por dia são equivalentes a 200 tragadas; ou seja, é como se fossem aplicadas 200 injeções intravenosas de nicotina por dia, causando dependência maior do que a cocaína ou a heroína, por exemplo.

E diverte com citações curiosas, com a do ditador coreano Kim Jong II, que disse, ao anunciar que estava parando de fumar: "Os fumantes estão entre os maiores imbecis do século, ao lado dos que não conhecem música e dos que ignoram os computadores".

Era uma vez um fumante

Quando: hoje, às $21 \mathrm{~h}$

Onde: no GNT

No recorte acima, da Folha de São Paulo, São Paulo, temos uma situação diferente. Apesar de muitos trechos parecerem ter sido retirados do relise, a verdade é que ambos usaram a mesma fonte: o documentário. Para redigir o texto de divulgação, o assessor de imprensa teve que assistir ao programa e selecionar os fragmentos que - a seu ver - mais pudessem 
interessar aos jornalistas. $O$ envio do relise em questão suscitou o interesse do veiculo, que solicitou uma cópia do documentário para a publicação de uma resenha sobre o programa.

Em ambos os textos, por exemplo, a declaração de Kim Jong II é citada integralmente, mas na matéria da Folha de S.Paulo o jornalista não citou o contraponto da primeira cena de Dom Juan de Molière destacado pelo relise. Todavia, foi esse texto de divulgação que despertou o interesse do jornalista, reforçando a importância que a seleção do assunto e a escolha das palavras e frases pelo assessor de imprensa têm, na "conquista" de um espaço na mídia.

Assim como os demais registros, a matéria destacada indica a atração, trazendo o serviço completo de título, assunto, data, horário e emissora. O diferencial, neste caso, é que, aqui, o documentário ganha maior evidência pois está num espaço nobre do caderno de cultura e variedades. Além disso, a matéria leva para os leitores do jornal, junto com a informação, uma carga de credibilidade que se define no momento da escolha do lugar em que o programa figura: na seção de crítica, e com ausência de comentários negativos sobre seu conteúdo. Sua importância pode ser percebida, ainda, pelo retorno em valores estimado, muito superior as demais notícias publicadas sobre a atração. 


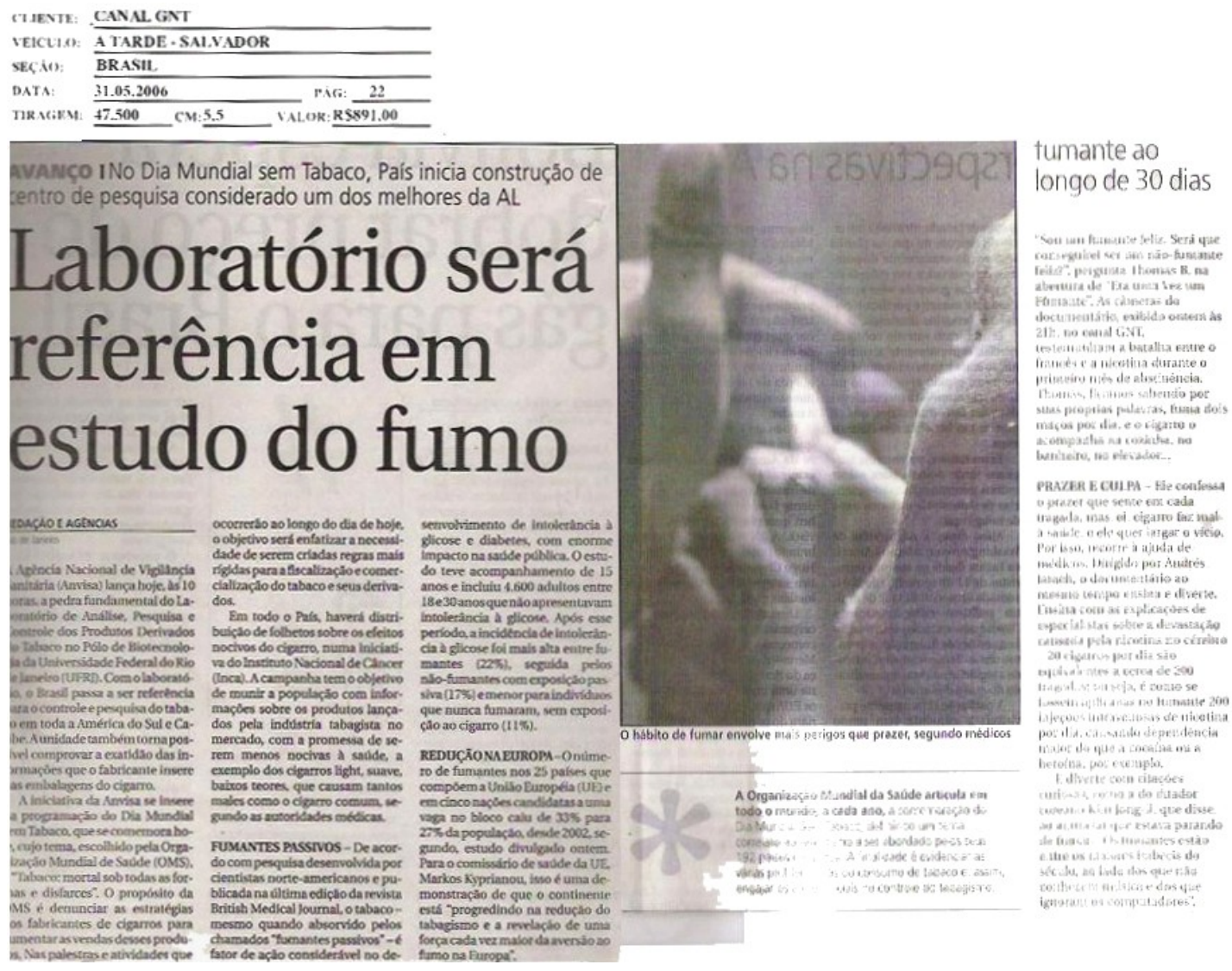

Laboratório será referência em estudo do fumo

A Agência Nacional de Vigilância Sanitária (ANVISA) lança hoje, às 10 horas, a pedra fundamental do Laboratório de Análise, Pesquisa e Controle dos Produtos Derivados do Tabaco no Pólo de Biotecnologia da Universidade Federal do Rio de Janeiro (UFRJ). Com o laboratório, o Brasil passa a ser referência para o controle e pesquisa do tabaco em toda a América do Sul e Caribe. A unidade também torna possível comprovar a exatidão das informações que o fabricante insere nas embalagens do cigarro.

A iniciativa da Anvisa se insere na programação do Dia Mundial Sem Tabaco, que se comemora hoje, cujo tema, escolhido pela Organização Mundial de Saúde (OMS), é "Tabaco: mortal sobre todas as formas e disfarces". O propósito da OMS é denunciar as estratégias dos fabricantes de cigarro para aumentar as vendas desses produtos. Nas palestras e atividades que ocorrerão ao longo do dia de hoje, o objetivo será enfatizar a necessidade de serem criadas regras mais rígidas para a fiscalização e comercialização do tabaco e seus derivados.

Em todo o País, haverá distribuição de folhetos sobre os efeitos nocivos do cigarro, numa iniciativa do Instituto Nacional de Câncer (Inca). A campanha tem o objetivo de munir a população com informações sobre os produtos lançados pela indústria tabagista no mercado, com a promessa de serem menos nocivos à saúde, a exemplo dos cigarros light, suave, baixos teores, que causam tantos males como o cigarro comum, segundo as autoridades médicas.

FUMANTES PASSIVOS - De acordo com pesquisa desenvolvida por cientistas norte-americanos e publicada na última edição da revista British Medical Journal, o tabaco - mesmo quando absorvido pelos chamados "fumantes passivos" - é fator de ação considerável no desenvolvimento de intolerância à glicose e diabetes, com enorme impacto na saúde pública. $\mathrm{O}$ 
estudo teve acompanhamento de 15 anos e inclui 4.600 adultos entre 18 e 30 anos, que não apresentavam intolerância à glicose. Após esse período, a incidência de intolerância à glicose foi mais alta entre fumantes $(22 \%)$, seguida pelos não-fumantes com exposição passiva (17\%) e menor para indivíduos que nunca fumaram sem exposição ao cigarro (11\%).

REDUÇÃO NA EUROPA - O número de fumantes nos 25 países que compõe a União Européia (UE) e em 5 nações candidatas a uma vaga no bloco caiu de $33 \%$ para $27 \%$ da população, desde 2002 , segundo, estudo divulgado ontem. Para o comissário de saúde da UE, Markos Kyprianou, isso é uma demonstração de que o continente está "progredindo na redução do tabagismo e a revelação de uma força cada vez maior da aversão ao fumo na Europa".

Fumante ao longo de 30 dias

"Sou um fumante feliz. Será que conseguirei ser um não-fumante feliz?", pergunta Thomas B. na abertura de "Era Uma Vez Um Fumante". As câmeras do documentário, exibido ontem às $21 \mathrm{~h}$ no canal GNT, testemunharam a batalha entre o francês e a nicotina durante o primeiro mês de abstinência. Thomas, ficamos sabendo por suas própria palavras, fumava dois maços por dia, e o cigarro o acompanhava na cozinha, no banheiro, no elevador...

PRAZER E CULPA - Ele confessa o prazer que sente em cada tragada, mas, ei, cigarro faz mal á saúde e ele quer largar o vício. Dirigido por Andrés Jarach, o documentário ao mesmo tempo informa e diverte. Ensina com as explicações de especialistas sobre a devastação causada pela nicotina no cérebro - 20 cigarros por dia são equivalentes a 200 tragadas; ou seja, é como se fossem aplicadas 200 injeções intravenosas de nicotina por dia, causando dependência maior do que a cocaína ou a heroína, por exemplo.

Nessa outra matéria do jornal A Tarde, de Salvador, Bahia, configurase a possibilidade comentada no capítulo teórico, de que é possível trabalhar um mesmo assunto em diferentes segmentos editoriais, desde que se faça de forma pertinente. Ou seja, tendo como gancho o Dia Mundial Contra o Tabaco, o documentário foi inserido numa reportagem sobre o tema, porém fora dos cadernos de variedades, como seria esperado. Com lugar de destaque, no canto superior na matéria com direito até a sub-título, a presença do documentário numa editoria como "Brasil" o coloca em evidência junto a um público que não necessariamente conhece e acompanha a programação do canal GNT.

Uma questão muito mais curiosa é que a matéria, publicada um dia depois da exibição do documentário, transcreve não o relise mas a crítica da Folha de S.Paulo. Muito comum na imprensa nacional - e até no exterior - as agências de notícias repassam suas matérias criando um "eco" das publicações originais. Isso oferece ainda um novo fôlego ao assessor de imprensa no seu trabalho de divulgação. 
Recorte 9

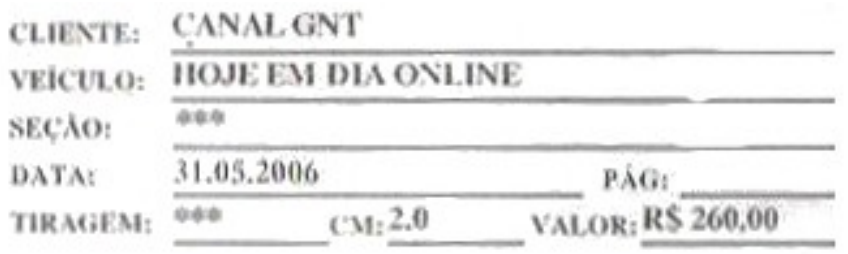

O bom da telinha

Hoje em Dia - MG - Cultura - 31/05:2006

O GNT exobe hoje -Era uma Vez um Fumarte. As cameras do documentario tostemunham a balalha ente um francos ex-fumante e a nicotha dutante o primeiro mos de abstinencia. Dirigido por Andiés Jarach, o dccumentatio ao mesmo tempo ensina e diworte. GNT, 21 horas.

O bom da telinha

O GNT exibe hoje "Era Uma Vez Um Fumante". As câmeras do documentário testemunham a batalha de um francês ex-fumante e a nicotina durante o primeiro mês de abstinência. Dirigido por Andrés Jarach, o documentário ao mesmo tempo ensina e diverte. GNT, 21 horas.

Não podemos nos esquecer ainda de uma outra vertente que vem crescendo diariamente: a imprensa online. Apesar de volumoso e variado, o conteúdo editorial dos sites brasileiros ainda não alcançou o estudo e reconhecimento necessários, muitas vezes por ser considerado uma imprensa ainda "amadora". Assim como nos veículos impressos, o relise pode suscitar simples registros - como no recorte acima do jornal Hoje em Dia, de Minas Gerais -, ou matérias mais elaboradas. 


\begin{tabular}{|c|c|c|}
\hline CLIENTE: & CANAL GNT & \\
\hline VEICTAS: & GUIA DA SEMANA & \\
\hline SHC.AO: & 060 & \\
\hline DATA: & $31,05.2006$ & Pigi: 064 \\
\hline TIRACIEM: & Dot $\quad$ CM: 10.0 & VALOR: R\$ 298,00 \\
\hline
\end{tabular}

Era Uma Vez Um Fumante estréla no GNT

fucia da Semana - 31/05/2006

A. Stioa hojo (31:05), Dia Mundlal de Lua Contra o Tabaco, as 21h, o documentário incelito 'Era Uma Yoz Um Fumanto: Dísigido por Andtés Jarach, o programa mostra a trajotoria de Thomas B. em seu pinnelro mos como ex fumante.

Uiaguoniticado como nivel 4 no testo de depenxıoncia lisica Fagerström, o ponto de partida para essa mudança está calcado no fascinio do protagonista pelos personagons de Clint Eastwood nos cldunicos filmes do taroeste, onde a indofectivel cigarritha é presença constante em todas as cenas do "mocinito", Os flashs dos teitos herólcos da personagem em sua mente, cada vez mais, fazem a wontado de fumar ser crescento e Thomas lança uma pergunta a si proprio: "Por quo parar do lazer unas colta que tapo tho bem?".

Pare óm lumante do peso como Thomas, que consumia o equivalente a doze mi injecōes jutravenosas do nikotina mensalmente - o que compreende 40 cigarros ao dia - continuar seguindo juma vida envolta en fumaça parece ser a opçào mais prazerosa. Mas com a ajuda de um time de espocialistas, entre eles cardiologistas, nutricicoistas, psicalogos e ate hipnoterapeitas, a batalha contra o fumo o iniciada.

O documentario mostra ainda experienclas taboratoria's com cobaias, os niveis de dependencia do elgarro retacionodo a cocaina e heroina, as prodisposiçöes que fazem um individuo se tornar dependente, e monta um verdadele arsenal de chichetes de nicolina, inaladores, excercicios díarios $e$ uma dieta bolancotda a base de proteinas of frutas como atmas no combato ao vicio.

Era Uma Vox Um Fumante

GNT-Canal Globosat NET i Sky 41

Estróla quarta-loira (31/05), às $21 \mathrm{~h}$

Horário alternativo: quinta-leira $(01 / 06)$, às 12h30

Era uma vez um fumante estréia no GNT

Estréia hoje (31/05), Dia Mundial de Luta Contra o Tabaco, às 21h, o documentário inédito Era Uma Vez Um Fumante. Dirigido por Andrés Jarach, o programa mostra a trajetória de Thomas $\mathrm{B}$. em seu primeiro mês como exfumante.

Diagnosticado como nível 4 no teste de dependência física Fagerström, o ponto de partida para essa mudança está calcado no fascínio do protagonista pelos personagens de Clint Eastwood nos clássicos filmes de faroeste, onde a indefectível cigarrilha é presença constante em todas as cenas do "mocinho". Os flashs dos feitos heróicos da personagem em sua mente, cada vez mais, fazem a vontade de fumar ser crescente e Thomas lança uma pergunta a si próprio: "Por que parar de fazer uma coisa que faço tão bem?".

Para um fumante de peso como Thomas, que consumia o equivalente a doze mil injeções intravenosas de nicotina mensalmente - o que compreende 40 cigarros ao dia - continuar seguindo uma vida envolta em fumaça parece ser a opção mais prazerosa. "Tornar-se abstêmio é fácil, seguir abstêmio é que é realmente difícil", diz ele. Mas com a ajuda de um time de especialistas, entre eles cardiologistas, nutricionistas, psicólogos e até hipnoterapeutas, a batalha contra o fumo é iniciada.

O documentário mostra ainda experiências laboratoriais com cobaias, os níveis de dependência do cigarro relacionado a cocaína e heroína, as predisposições que fazem um indivíduo se tornar dependente, e monta um verdadeiro arsenal de chicletes de nicotina, inaladores, exercícios diários e uma dieta balanceada a base de proteínas e frutas como armas no combate ao vício.

Uma outra tendência desse segmento "virtual" da mídia, quase inexistente na grande imprensa, é a publicação do texto integral do relise, como no caso da matéria acima, publicada no site Guia da Semana, de São 
Paulo, que apenas mudou a data do texto para o dia de sua publicação no site, mantendo, inclusive, o mesmo título do relise. 
Com base nas matérias publicadas referente ao relise de divulgação, trazemos mais uma vez o texto integral, agora destacando - juntos - todos os trechos retomados pelas matérias para dar uma visão mais ampla de sua utilização pelos jornalistas. Excluímos dessa amostragem as citações referentes ao dia, horário e canal de exibição, assim como o nome do documentário - informações presentes em todos os registros. Lembramos, ainda, que o último exemplo transcreveu o relise integralmente,

\section{Era Uma Vez Um Fumante estréia no GNT}

Estréia no próximo dia (31/05), Dia Mundial de Luta Contra o Tabaco, às 21h, o documentário inédito Era Uma Vez Um Fumante. Dirigido por Andrés Jarach, o programa mostra a trajetória de Thomas B. em seu primeiro mês como ex-fumante.

Diagnesticade como nível 4 no teste de dependência física Fagerström ponte de partida para essa mudanca está calcade no fascínio de protagonista pelos personagens de Clint Eastwoed nos clássicos filmes de faroeste unde a. indefectível cigarcilha é presenca censtante em tedas as cenas de "mecinho". Os flashes dos feitos heróicos da personagem em sua mente, cada vez mais, fazem a vontade de fumar ser crescente e Thomas lança uma pergunta a si próprio: "Por que parar de fazer uma coisa que faço tão bem?".

Junto a isso, a jornada começa com uma dualidade que salta aos seus olhos. De um lado, lendo uma matéria jornalística, ele se depara com uma declaracão do tirano coreano Kim Jong II que diz: "Os fumantes estão entre os maiores. imbecis do século, ao lado dos que não conhecem música e dos que ignoram. os computadores". Do outro, uma fala da primeira cena, do primeiro ato de Don Juan de Molière: "O tabaco é a paixão das pessoas honestas e quem vive sem fumo não é digno de viver".

Para um fumante de peso como Thomas, que consumia o equivalente a doze mil injeções intravenosas de nicotina mensalmente - - o que. compreende 40 cigarros ao dia - continuar seguindo uma vida envolta em fumaça parece ser a opção mais prazerosa. "Tornar-se abstêmio é fácil, seguir abstêmio é que é realmente difícil", diz ele. Mas com a ajuda de um time de especialistas entre eles cardiologistas nutricionistas ....psicólogos e e...atét. hipnoterapeutas, a batalha contra o fumo é iniciada.

O documentário mostra ainda experiências laboratoriais com cobaias, os níveis de dependência do cigarro relacionado a cocaína e heroína, as predisposições que fazem um indivíduo se tornar dependente, e monta um verdadeiro arsenal de chicletes de nicotina, inaladores, exercícios diários e uma dieta balanceada a base de proteínas e frutas como armas no combate ao vício. (grifos nossos)

Em resumo, é possível aqui verificar o alcance do relise na mídia e a variedade de formas como ele repercute, de acordo com o impacto que gera em seu interlocutor. Fato é que ele cumpre sua missão: despertar o interesse dos jornalistas das redações para que noticiem o objeto divulgado. 
CONSIDERAÇÕES FINAIS 
"O problema não está na existência de certos estilos de linguagem, dialetos sociais, etc., existência essa estabelecida por meio de critérios meramente lingüísticos; o problema está em saber sob que ângulo dialógico eles se confrontam ou se opõe na obra. Mas é precisamente esse ângulo dialógico que não pode ser estabelecido por meio de critérios genuinamente lingüísticos, porque as relações dialógicas, embora pertençam ao campo do discurso, não pertencem a um campo puramente lingüístico em seu estudo".

(BAKHTIN, Mikhail [1997] Problemas da Poética de Dostoiévski, p.182) 


\section{CONSIDERAÇÕES FINAIS}

Ao começar a escrever esta dissertação, tínhamos a intenção não apenas de definir o gênero relise, mas também de caracterizá-lo, de acordo com suas peculiaridades lingüísticas e composicionais. Ao nos debruçarmos sobre as análises desses textos, percebemos a inviabilidade de se postular um modelo de relise único e estático, já que eles seguem diferentes estilos de acordo com seu contexto específico de produção. Isso porque, apesar de seu caráter uniforme, as relações dialógicas que estabelece com seu interlocutor não podem ser ignoradas.

Mais uma vez Bakhtin é a fonte teórica que norteia nossos pressupostos, na releitura de Irene Machado (2005):

"A intenção do autor se realiza em função de uma escolha efetuada dentre as formas estáveis dos enunciados. Com isso, Bakhtin afirma a importância do contexto comunicativo para a assimilação desse repertório de que se pode dispor para enunciar uma determinada mensagem. Isso porque os gêneros discursivos são formas comunicativas que não são adquiridas em manuais, mas sim nos processos interativos" (p.157).

Beth Brait (2005) também traz sua contribuição sobre a obra do lingüista sob a ótica do estilo:

"Para definir os gêneros discursivos, um dos aspectos destacados é o fato de que eles transitam por todas as atividades humanas e devem ser pensados, culturalmente, a partir de temas, formas de composição e estilo. Isso significa que, além da atividade literária, todas as demais atividades implicam gêneros e, consquentemente, estilos" (p.88).

E é ao próprio Bahktin (1997) que recorremos para focar um último e importante ponto nesse quesito:

"O problema não está na existência de certos estilos de linguagem, dialetos sociais, etc., existência essa estabelecida por meio de critérios meramente lingüísticos; o problema está em saber sob que ângulo dialógico eles se confrontam ou se opões na obra. Mas é precisamente esse ângulo dialógico que não pode ser estabelecido por meio de critérios genuinamente lingüísticos, porque as relações dialógicas, embora pertença, ao campo do discurso, não pertencem a um campo puramente lingüístico em seu estudo" (p.182).

Foi possível observar nas análises apresentadas, que nem elas nem o seu objeto seguem um padrão único, pois estão alicercadas nos traços 
mais marcantes do estilo de cada texto. Ou seja, um relise com uma carga de subjetividade aflorada como o das novas tendências da marca Zoomp para o inverno não pode ser analisado sob a mesma ótica do texto repleto de termos técnicos para apresentar a novidade tecnológica da Vivo, no ramo de telefonia móvel.

Retomando as "condições de êxito" propostas por Maingueneau, podemos dizer que os relises se enquadram nas categorias definidas por ele como pressupostos para caracterizar um único gênero. Os relises são primordialmente escritos e impressos (suporte material) por um profissional de Assessoria de Imprensa para os jornalistas de redação (estatuto de parceiros legítimos), apresentados em textos informativos que pretendem despertar o interesse desses jornalistas (finalidade reconhecida), elaborados tendo sempre em vista uma leitura fácil, rápida e atraente (lugar e momento legítimos). Já com relação a sua organização textual, mesmo não seguindo um modelo estático, trazem aspectos de textualidade, recursos persuasivos e estilo próprio, adequados ao objeto que testa o relise.

Numa primeira leitura do corpus, foi possível, ainda, perceber que os relises se assemelham ao discurso jornalístico, mas, à medida que as análises se aprofundavam, ficava evidente o ponto em que os gêneros se diferenciam: o papel de atividade sócio-discursiva do relise. Apesar de usar linguagem jornalística conhecida e praticada por seus interlocutores, o assessor de imprensa emprega recursos retóricos, persuasivos e - em certos casos - poéticos, em busca da atenção de seu interlocutor. O caso do relise sobre a rede D'Avó de Supermercados, por exemplo, transcende o estilo jornalístico, estabelecendo uma ponte para a narrativa do gênero ficcional, como recurso persuasivo.

Em termos práticos, este estudo possibilita a comprovação de que a realização lingüística praticada pelas assessorias de imprensa, e inserida no gênero relise, se faz pela sinergia entre o uso de elementos do discurso jornalístico, recursos persuasivos e estilos pré-estabelecidos pelas relações com seus interlocutores. Ou seja, o grau de aceitação e eficiência do relise junto à imprensa está instrinsecamente ligado ao seu processo de produção e suas escolhas lingüísticas. 
Sabemos que a pesquisa apresentada aquí é apenas um primeiro passo na conceituação e caracterização do gênero relise. O material disponível para análise é vasto, em contrapartida a uma reduzida bibliografia sobre o assunto, o que coloca o presente trabalho como um ponto de partida para outros estudos acerca do tema.

Ainda assim, esperamos ter cumprido o objetivo pioneiro de mostrar o relise como um novo gênero, com conteúdo temático, estilo e construção composicional próprios, definido por uma relação sócio-interativa única que o diferencia dos demais gêneros já estudados.

Acreditamos ter evidenciado o efeito persuasivo de recursos de linguagem e estilo, apontado exemplos como: emprego de formas verbais; enumerações; vocabulário de campos semânticos específicos; emprego de trechos narrativos e descritivos; dados estatísticos; citações de opinião de autoridade; figuras como aliterações, metáforas, comparações. Também pensamos ter deixado claro que a composição dos relises - por mais diversos que sejam uns dos outros - apóia-se num recurso central: a persuasão, a vontade de convencer o interlocutor, de conquistar espaço na mídia para o objeto apresentado.

Esperamos ter, também, contribuído para a maior competência do redator de relises, oferecendo um suporte para os assessores de imprensa, ainda carentes de fontes bibliográficas em sua área de atuação. Refletir sobre a produção da área pode ser uma experiência enriquecedora. 
ANEXOS 


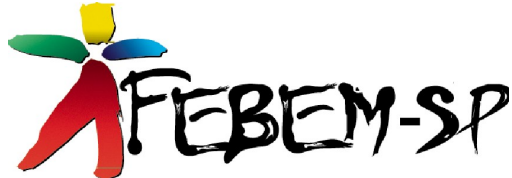

\section{Fundação Estadual do Bem-Estar do Menor}

\section{UMA CIDADE DENTRO DA FEBEM}

Alamedas arborizadas, escola para 500 adolescentes, posto médico, teatro com 400 lugares, biblioteca com 2.000 livros, padaria, loja, piscina, quadras, campo de futebol, academia, estúdio fotográfico, emissora de rádio. Essa poderia ser a descrição de uma cidade qualquer do interior paulista, mas se trata do maior complexo da Febem, no bairro do Tatuapé.

Com mais "habitantes" que municípios como Alvilândia, Borá, Dolcinópolis, Flora Rica, São João de Iracema ou Santa Salete, o Complexo deixa evidente a sua grandiosidade nos números: 230 mil $\mathrm{m}^{2}$ abrigam 17 unidades de internação, com 1.560 adolescentes e 1.300 funcionários. Por dia são servidas 9.000 refeições e circulam semanalmente por suas ruas uma média de 400 veículos. Nos finais de semana, quando acontecem as visitas, o Tatuapé aumenta o número da população: são cerca de 1.500 visitantes. Só em 2003, deram entrada no Complexo 2.800 jovens e outros 1.600 foram desinternados.

Todas as unidades do complexo oferecem ensino fundamental e médio, em salas de aula, além de atividades profissionalizantes, culturais e esportivas. Os jovens podem escolher entre atividades como artes plásticas, biscuit, digitação, educação ambiental, elétrica residencial, fotografia, informática, mecânica, pintura automotiva, manutenção de microcomputador, panificação, confeitaria, serigrafia, arraiolo, artesanato, tapeçaria, acabamento em móveis, pirogravura, cartonagem, encadernação, fábrica de bolas, pintura em vidro, capoeira, oficina de percussão, cavaco, teclado, violão, arte circense, canto coral, dança de rua, teatro, orquestra, produção de vídeo, confecção de berimbau, atletismo, basquete, boxe, cama elástica, ciclismo, futebol de campo, futebol de salão, futebol society, ginástica, ginástica acrobática, handebol, musculação, pebolim, skate, tênis de mesa, tênis de quadra, voleibol e xadrez.

O Complexo também tem uma escola profissionalizante e uma escola de ensino formal. A Escola Profissionalizante Marina Vieira de Carvalho Mesquita oferece em suas dependências 31 oficinas, além de coordenar as atividades profissionalizantes realizadas dentro de cada unidade. Já a Escola Oficina Rosmay Kara José é a responsável pelo ensino fundamental e médio. Recebe em suas dependências, os jovens das unidades que não têm salas de aula. Dentro do Complexo também funcionam a Divisão de Saúde, Divisão de Segurança, manutenção, lavanderia e cozinha industrial que atendem grande parte das unidades do Estado. 
O PREFEITO - No comando desta super-estrutura desde abril de 2003, está o diretor de divisão, Celso Vieira. Formado em administração de empresas, com especialização em recursos humanos, o "prefeito" do Tatuapé, como é carinhosamente chamado, implantou um estilo diferente de gerenciamento, valorizando a formação de equipes e treinamento dos funcionários. "Respeitando as características de cada unidade e seguindo um padrão, dei autonomia para que os diretores pudessem trabalhar de acordo com as suas necessidades. Esse foi um dos pontos principais para que as unidades funcionassem de maneira tranqüila durante o ano", explica. Outro fator importante é que o diretor do Complexo começou, há quinze anos, como funcionário de pátio. "Essa experiência do monitor que virou diretor de divisão faz com que os funcionários se sintam mais próximos e o entrosamento com a área técnica é muito maior", conclui Vieira

HISTÓRIA - Em 1902, com o projeto de criação de um instituto disciplinar para jovens infratores, do chefe de polícia de São Paulo, Cardoso de Almeida, o governo do Estado desapropriou a Chácara do Belém e inaugurou a Escola Correcional. A idéia era que lá fossem recolhidos jovens abandonados e pequenos criminosos, que até então ficavam em cadeias com adultos. O primeiro interno chegou à escola em 23 de fevereiro de 1902.

SP 450 ANOS - A "cidade" da Febem também irá comemorar os 450 anos da capital paulista, com o $5^{\circ}$ Encontro de Dança de Rua, no dia 25 de janeiro, às 11 horas. São cerca de 300 adolescentes que participam da oficina de Dança de Rua, promovida em várias unidades do Estado pelo Ballet Stagium. Ao final do evento, os participantes cantam parabéns para a cidade com um bolo feito pelos próprios adolescentes do Tatuapé. 


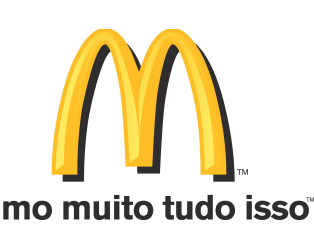

\title{
Saladas do McDonald's chegam ao prato EM PORÇÕES MAIS GENEROSAS
}

\author{
Com embalagem inédita, as novas versões da Salad Green \\ e da Salad Green Chicken são as maiores novidades da campanha \\ de verão da rede, que traz mais quatro lançamentos
}

As saladas do McDonald's são o prato do dia, ou melhor, da temporada. A rede de restaurantes tornou ainda mais generosas as porções da Salad Green e da Salad Green Chicken - que passaram de 117g para 142g, e de $147 \mathrm{~g}$ para cerca de $215 \mathrm{~g}$, respectivamente - e começa agora a servi-las em pratos. As novas versões dos produtos e sua embalagem - nunca antes utilizada pela empresa no Brasil - são os principais destaques do Verão McDonald's 2004. A campanha, que começou em 27 de dezembro e se estenderá até 29 de fevereiro, apresenta outros quatro saborosos lançamentos: um sanduíche, duas sobremesas e um suco.

A estréia das saladas no cardápio da rede ocorreu há três anos, durante o Verão McDonald's 2001. O sucesso foi tão grande que a rede - sempre empenhada em oferecer qualidade e variedade a seus clientes - incorporou os produtos definitivamente ao cardápio no final daquele ano. Antes servidas em copos plásticos de $500 \mathrm{ml}$, as saladas conquistaram, em particular, o paladar feminino, que tem predileção por refeições mais leves e, também, à base de frango.

As novas versões das Salad Green e da Salad Green Chicken, que podem ser saboreadas com os molhos Ceasar e Vinagrete, vieram para ficar. Já os demais lançamentos do Verão McDonald's 2004 permanecerão em cartaz durante a campanha. É o caso do sanduíche McXSalada Bacon, produto sazonal que volta regularmente ao cardápio, sempre com grande aceitação. A mesma regra vale para as duas sobremesas da temporada - o Novo Muito Tudo e o Novo Sundae de Framboesa, ambos à base de sorvete de baunilha - e o McFruit Limão, a quarta opção de sabor da nova linha de sucos do McDonald's Brasil, desenvolvida sob medida pela Minute Maid, empresa do Grupo Coca-Cola.

O Verão McDonald's 2004 será divulgado em campanha publicitária assinada pela Taterka Comunicações. O slogan "amo muito meu verão" terá presença de destaque em dois filmes de 45 segundos, spots de rádio, outdoors, banners na Internet e peças de mobiliário urbano. No interior dos restaurantes, displays, móbiles, faixas e embalagens coloridas darão o tom da nova estação. 


\section{VERÃO McDONALD’S 2004 - LANÇAMENTOS}

Green Salad: alface americana, alface romana, alface lisa, cenoura, repolho roxo, lascas de queijo parmesão e tomate;

Green Salad Chicken: alface americana, alface romana, alface lisa, cenoura, repolho roxo, lascas de queijo parmesão e tiras de filé de frango empanado crocante;

McXSalada Bacon: hambúrguer de carne bovina, molho tipo maionese, tomate, alface, queijo e duas fatias de bacon;

Novo Muito Tudo: sorvete de baunilha, com cobertura de morango e chocolate, farofa de cereal tostado e dois bijus;

Novo Sundae de Framboesa: sorvete de baunilha, com calda de framboesa;

McFruit Limão 


\section{ZOOMP}

\section{Black Panther Party - Zoomp Inverno 2004}

Há um perfume dos anos 70 no ar. Apenas um perfume. Influências da estética black \& soul e essências orientais permeiam o Inverno 2004 da ZOOMP. Ícones do espírito de liberdade e igualdade como os Panteras Negras, Angela Davis, Jim Morrisson, Janis Joplin, e o mistério do Oriente compõem a fonte de inspiração para um grande evento onde se reúnem os ciganos urbanos, cidadãos antenados, nômades de nossos dias. A resultante deste universo pode ser traduzida em uma festa de transformações e de conquistas na qual o poder negro foi determinante, contagiando tendências. Nesta atmosfera, o sexy definitivamente se consagra como alma e sinônimo da marca.

O Jeans é protagonista. Tratado de forma diferenciada, materializa os sonhos e desejos de uma década, surgindo nas mais variadas lavagens e padronagens. Formas que recriam túnicas, kaftans, batas, resgatando detalhes preciosos da cultura pop dos anos 70 . O jeans surrado e desbotado - Vintage Stone Washed - revive uma das primeiras lavagens utilizadas pela marca, em 1974. De tonalidade azul clara, quase um délavé, passeia por peças de modelagens não convencionais. $O$ black é apresentado com efeitos desbotados. Uma luz sutil ilumina o conjunto. Calças de modelagem tradicional, jaquetas e batas em sarja com punhos. Ainda o jeans, define a alfaiataria com paletós, casacos e jaquetas em jeans espinha de peixe nos quais texturas simulam o aspecto gasto.

O desejo de reler esses elementos de uma forma nova traduz-se na predominância de vários tons de preto sobrepostos que sugerem e simbolizam a diversidade de referencias inspiradoras. É a sobreposição de culturas compondo e alimentando a alma criativa. Aplicações de guizos, moedas, medalhas, penduricalhos e franjas reforçam o espírito de celebração, do ritual. Black Panther Party.

ENJOY the Party 


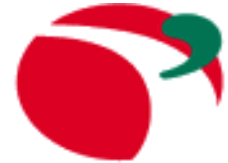 \\ D'avó Hiper}

\section{FAMÍLIA D’AVÓ: UMA HISTÓRIA DE VANGUARDA E SUCESSO}

Quase meio século de Brasil colocando o consumidor em primeiro lugar

Quando Dionísio De Avó chegou ao Brasil, em 1951, vindo de Portugal, o imigrante nem imaginava o sucesso que lhe aguardava. Hoje, 51 anos depois, ele vê seu sonho, que começou no ramo da panificação, transformar-se no D'Avó Supermercados, uma respeitada rede que conta com cinco lojas na Zona Leste de São Paulo e dois hipermercado na região do Alto Tietê. A rede D'Avó figura hoje em oitavo lugar no ranking estadual de supermercados ( $21^{\circ}$ no nacional), com um faturamento bruto de $\mathrm{R} \$ 388$ milhões em 2002. E quer crescer !

A história de Dionísio e, por conseqüência, de toda a rede, é pontuada por pioneirismos e ousadia. Em 1955, o imigrante português arriscou-se no ramo de panificação, entregando leite e pão de porta em porta. Cinco anos depois, foi aberta a primeira padaria, no bairro do Butantã. "Depois de estabelecido, mandei vir de Portugal 14 familiares, entre primos e irmãos", lembra o empreendedor. Com a vinda dos parentes, outras cinco padarias foram abertas pela cidade, sempre com total identificação com a comunidade local. "Nossa cultura de atendimento ao consumidor veio dessa experiência vitoriosa no ramo de panificação", conta Martinho Paiva Moreira, diretor comercial do D’Avó e filho de um dos sócios.

No começo da década de 80 , incentivados pela população do conjunto habitacional Cohab, onde os De Avó tinham duas padarias, surgiu a oportunidade de participar da concorrência para a abertura de um supermercado no local. O projeto, audacioso, exigia a venda das seis padarias, a união da família e uma dose extra de ousadia. "Foi uma aventura, porque nossos pais e tios saíram de um ramo que eles conheciam profundamente para ingressar no segmento supermercadista", lembra o diretor comercial Toninho De Avó, da segunda geração da família. "Fiquei um pouco inseguro, mas a nova geração da família me encorajou", confessa Dionísio. Os De Avó ganharam a concorrência e montaram uma loja com 2000 m2. 
A partir de 1983, com a inauguração da primeira loja em Itaquera, o grupo cresceu, conquistou definitivamente a clientela da região onde se instalou e é referência no segmento. O D'Avó marca presença em outros quatro endereços na Zona Leste - Parque São Lucas (inaugurado em 1986), Guaianazes (1991), São Miguel (1994), Itaim Paulista (1996) - e dois hipermercados na região do Alto Tietê - Suzano (1999), Mogi das Cruzes (2001).

Pioneirismo é a palavra para definir o espírito da família e de seu negócio. O D’Avó foi a primeira loja de varejo totalmente informatizada, da retaguarda ao caixa, inaugurando a automação comercial como ela é conhecida hoje. E isso foi em 1991, na loja de Guaianazes. O conceito de PDV modular foi introduzido no mercado pelo D'Avó em 92. A política de precificação adotada pela rede também é pioneira: os preços dos produtos na gôndola tem excelente visibilidade, deixando claro para o consumidor o preço e a discriminação de cada produto.

Outro grande exemplo de inovação é o Cartão Confiança, criado em 97, o primeiro Smartcard do segmento, que oferece crédito aos clientes do D'Avó e atende hoje mais de 200 mil famílias, agilizando e facilitando o processo de compra e pagamento. E a iniciativa deu tão certo que o D’Avó agora oferece também o Confiança Empresa, um substituto da cesta básica.

Procurando cada vez mais melhorar o atendimento à seus clientes, $\mathrm{O}$ D'Avó investe também em eventos internos que promovam o interesse e a participação de seus funcionários para aprimorar a relação com o cliente. Implantação de TeleCurso, Projeto Jovem Cidadão e Desenvolvendo talentos são algumas das iniciativas da rede. Outra grande preocupação é manter o bom relacionamento que conquistaram junto à comunidade nesses 18 anos de existência realizando regularmente ações sociais nas região em que atua.

E a trajetória de vanguarda dos onze sócios não acabou. Para as duas gerações que atualmente conduzem os negócios, atender bem seus clientes continua sendo o desafio mais importante da rede. Um dos principais dentre os muitos que virão. Porque, na história da família D'Avó, desafio é sinônimo de sucesso. 


\section{vivo}

\section{Vivo é a primeira operadora do país a oferecer serviço de vídeo no celular}

\section{A operadora lança quatro aplicativos para o serviço com tecnologia downloads e streaming para rodar filmes no celular $A$}

Se você acha que já sabe tudo sobre celulares, reconsidere. A partir desta semana, a Vivo inaugura uma nova era para a telefonia móvel: a era do vídeo no celular.

A maior operadora de telefonia móvel da América do Sul sai na frente da concorrência e lança no Brasil o serviço de vídeos no celular. São quatro aplicativos veiculados pelo serviço Vivo downloads e baseados na tecnologia brew, com soluções de vídeo downloading e vídeo streaming, disponíveis nas praças onde a operadora atua com a rede CDMA. O processo de desenvolvimento durou seis mêses, envolvendo a análise das melhores soluções fornecidas por seis potenciais parceiros tecnológicos, que culminou na escolha da T-Midia, como provedora da solução de vídeo e I-House, na integração com câmeras periféricas.

Os aplicativos serão lançados em série a partir desta semana para inclusão no ambiente de Vivo Downloads, já lançado em março de 2003 pela Vivo. Por isto seguem a tarifação do Vivo Downloads, a partir de R\$ 0,04 centavos o Kilobyte em regiões 1XRTT e custo de uma ligação local nas outras regiões. Os serviços de vídeo são compatíveis com aparelhos disponíveis no mercado - LG Life, Motorola T720, Samsung Twist e Toshiba Audiovox.

A partir da solução downloading, o usuário poderá baixar e assistir vídeos no celular. Neste sistema a operadora já estréia com dois aplicativos. O Vídeo On Demand oferece trailers de longa-metragem de grandes estúdios; em breve terá ampliação do menu com filmes de carros, em parceria com a revista Quatro Rodas e vídeo-clips de música. Já a Spicy TV é o canal de vídeos eróticos, com assinatura da Promogard. Para garantir eventuais restrições de acesso, a operadora fornece senha de proteção e a opção de black-list, que bloqueia o acesso ao canal mediante pedido do usuário.

Com a solução de "vídeo streaming", disponível em áreas cobertas com a rede CDMA 1x RTT, não há necessidade de armazenar o vídeo no celular, já que a maior vantagem é a informação em tempo real. Por isso, o streaming é direcionado a comportar aplicativos cujo conteúdo precisa de atualização constante. Neste sistema a operadora apresenta o Vídeo Trânsito, um serviço que mostra imagens dos principais pontos da cidade em tempo real, auxiliando o motorista a escolher as melhores vias para trafegar. 
Outra novidade é o Vídeo ao Vivo. Com software baixado em um computador mais uma câmera de vídeo compatível ligado a ele (a Vivo indica pelo menos 30 já disponíveis no mercado), o usuário pode fazer monitoramento de imagens em tempo real, para atender às questões de segurança, entretenimento e negócios.

À distância, o cliente poderá por exemplo acompanhar os passos do bebê, as férias dos amigos e dos parentes, o movimento da loja, a fachada da casa, etc.

Para oferecer a melhor relação custo $\mathrm{x}$ benefício ao usuário, os aplicativos em streaming são tarifados por assinatura mensal mais Kilobytes trafegados.

Os novos aplicativos chegam para sacudir o mercado. Com tarifas equivalentes a serviços já existentes e terminais disponíveis no mercado em faixa de preço compatível, a Vivo reduz a barreira de entrada e promete popularizar o acesso ao novo serviço. 


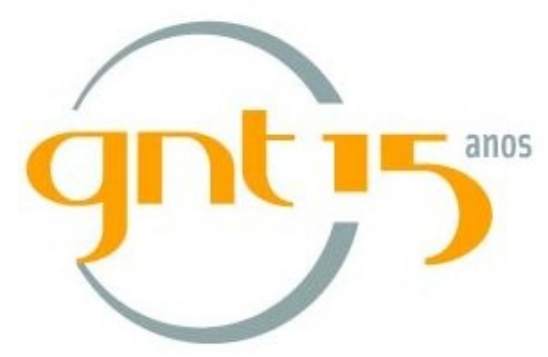

\section{Era Uma Vez Um Fumante estréia no GNT}

Estréia no próximo dia (31/05), Dia Mundial de Luta Contra o Tabaco, às 21h, o documentário inédito Era Uma Vez Um Fumante. Dirigido por Andrés Jarach, o programa mostra a trajetória de Thomas $B$. em seu primeiro mês como ex-fumante.

Diagnosticado como nível 4 no teste de dependência física Fagerström, o ponto de partida para essa mudança está calcado no fascínio do protagonista pelos personagens de Clint Eastwood nos clássicos filmes de faroeste, onde a indefectível cigarrilha é presença constante em todas as cenas do "mocinho". Os flashes dos feitos heróicos da personagem em sua mente, cada vez mais, fazem a vontade de fumar ser crescente e Thomas lança uma pergunta a si próprio: "Por que parar de fazer uma coisa que faço tão bem?".

Junto a isso, a jornada começa com uma dualidade que salta aos seus olhos. De um lado, lendo uma matéria jornalística, ele se depara com uma declaração do tirano coreano Kim Jong II que diz: "Os fumantes estão entre os maiores imbecis do século, ao lado dos que não conhecem música e dos que ignoram os computadores". Do outro, uma fala da primeira cena, do primeiro ato de Don Juan de Molière: "O tabaco é a paixão das pessoas honestas e quem vive sem fumo não é digno de viver".

Para um fumante de peso como Thomas, que consumia o equivalente a doze mil injeções intravenosas de nicotina mensalmente - o que compreende 40 cigarros ao dia - continuar seguindo uma vida envolta em fumaça parece ser a opção mais prazerosa. "Tornar-se abstêmio é fácil, seguir abstêmio é que é realmente difícil", diz ele. Mas com a ajuda de um time de especialistas, entre eles cardiologistas, nutricionistas, psicólogos e até hipnoterapeutas, a batalha contra o fumo é iniciada.

O documentário mostra ainda experiências laboratoriais com cobaias, os níveis de dependência do cigarro relacionado a cocaína e heroína, as predisposições que fazem um indivíduo se tornar dependente, e monta um verdadeiro arsenal de chicletes de nicotina, inaladores, exercícios diários e uma dieta balanceada a base de proteínas e frutas como armas no combate ao vício. 
Baixe imagem em alta definição desse documentário na Sala de Imprensa do GNT: www.holofote.com/gnt ou acesse direto pelo link download abaixo

18-05-2006

Era Uma Vez Um Fumante

Imagem de Divulgação

Era Uma Vez Um Fumante

GNT - Canal Globosat NET/ Sky\#41

Estréia quarta-feira (31/05), às $21 \mathrm{~h}$

Horário alternativo: quinta-feira (01/06), às $12 \mathrm{~h} 30$ 
BIBLIOGRAFIA 


\section{BIBLIOGRAFIA}

ALONSO, Damaso [1960]. Poesia Espanhola. Rio de Janeiro: Instituto Nacional do Livro.

BAKHTIN, Mikhail [2003]. Estética da criação verbal. São Paulo: Martins Fontes.

BAKHTIN, Mikhail [2002]. Marxismo e Filosofia da Linguagem: problemas fundamentais do método sócio-lógico na ciência da linguagem. São Paulo: Hucitec / Annablume.

BAKHTIN, Mikhail [1997]. Problemas da Poética de Dostoiévski. Rio de Janeiro: Forense Universitária

BEAUGRANDE, Robert-Alain de e DRESSLER, Wolfgang Ulrich [1981]. Introduction to text linguistics. London/New York: Longman.

BRAIT, Beth (org) [2005]. Bakhtin: Conceitos-chave.. São Paulo: Contexto.

BRANDÃO, Helena Nagamine [2001]. "Da língua ao discurso, do homogêneo ao heterogêneo" in Estudos Enunciativos no Brasil. São Paulo:

Pontes/Fapesp.

BRANDÃO, Helena Nagamine [1994]. "Coesão e Coerências Textuais" in Diário de Classe 3- Língua Portuguesa, FDE SE ESP.

BRANDÃO, Helena Nagamine (org) [2000]. Gêneros do Discurso na Escola: mito, conto, discurso político, divulgação científica. São Paulo: Cortez.

BRANDÃO, Helena Nagamine [2004]. Introdução à análise do discurso. Campinas: Cortez.

BRANDÃO, Helena Nagamine [1998]. Subjetividade, argumentação, polifonia. São Paulo: UNESP.

BRETON, Philippe [1999]. A argumentação na Linguagem. Subjetividade, argumentação, polifonia. Bauru: EDUSC.

CASTILHO, Ataliba T. de [1994]. "Teorias Lingüísticas e Ensino da Gramática" in Diário de Classe 3- Língua Portuguesa, FDE SE ESP.

CAMARA Jr., Joaquim Mattoso [1972]. Princípios de lingüística geral. Rio de Janeiro: Academia.

CHAROLLES, Michel [1978]. "Introduction aux problèmes de la cohérence des textes" in Langue Française 38. Paris: Larousse.

CHARAUDEAU, Patrick e MAINGUENEAU, Dominique [2004]. Dicionário de análise do discurso. São Paulo: Contexto.

CITELLI, Adilson [2002]. Linguagem e Persuasão. São Paulo: Ática.

CITELLI, Adilson [2003]. O texto argumentativo. São Paulo: Scipione. 
COHEN, Jean [1982]. "Poesia e redundância" IN O discurso da poesia. Poetique n²8. Coimbra: Livraria Almedina.

COSTA VAL, Maria da Graça [1999]. Redação e textualidade. São Paulo: Martins Fontes.

D'ONOFRIO, Salvatore [1983]. "Elementos estruturais do poema" IN O texto literário: teoria e aplicação. São Paulo: Duas Cidades.

DUARTE, Jorge [2003]. Assessoria de Imprensa e relacionamento com a mídia: teoria e técnica. São Paulo: Atlas

DUCROT, Oswald [1980]. "Analyses pragmatiques" IN Communication. Paris: Ed. Du Seuil.

DUCROT, Oswald [1978]. Présupposition et allusion. Mimeografado.

FÁVERO, Leonor Lopes [2002]. Coesão e Coerência textuais. São Paulo: Ática.

FENAJ (Federação Nacional dos Jornalistas) [1994]. Manual nacional de assessoria de imprensa. Rio de Janeiro: CONJAI/FENAJ.

FIORIN, José Luiz [2004]. Elementos de análise do discurso. São Paulo: Contexto.

FIORIN, José Luiz [1994]. "Modos de Organização do Discurso: a narração, a descrição e a dissertação" in Diário de Classe 3- Língua Portuguesa, FDE SE ESP.

HALLIDAY, M. A. K. E HASAN, Rugaia [1976]. Cohesion in English. London: Longman.

JAKOBSON, Roman [1977]. Lingüística e Comunicação. São Paulo: Cultrix.

JOLIBERT, Josette e colaboradores [1994]. "Quais os objetivos do aprendizado?" in Formando crianças produtoras de texto - Volume II. Porto Alegre: Artes Médicas Sul.

JORDAN, Isolde J [1994]. Introducción al análisis lingüístico del discurso. Heidelberg: Gottfried Geert Verlas.

$\mathrm{KOCH}$, Ingedore G. Villaça [2002]. A coesão textual. São Paulo: Contexto.

KOCH, Ingedore G. Villaça [2002]. Argumentação e Linguagem: São Paulo: Cortez.

KOCH, Igedore G. Villaça e TRAVAGLIA, Luiz Carlos [2002]. A coerência textual. São Paulo: Contexto.

KOCH, Ingedore G. Villaça e TRAVAGLIA, Luiz Carlos [1995]. Texto e Coerência. São Paulo: Cortez.

KOPLIN, Elisa e FERRARETTO, Luiz Artur [2000]. Assessoria de imprensa: teoria e prática. Porto Alegre: Sagra Luzzatto. 
LIMA, Gerson Moreira [1985]. Releasemania: uma contribuição para o estudo do press-release no Brasil. São Paulo: Summus.

LEVIN, Samuel R [1975]. Estruturas lingüísticas em poesia. São Paulo: Cultrix/Edusp.

LOPES, Boanerges [1995]. O que é Assessoria de Imprensa. São Paulo: Brasiliense.

MACHADO, Irene [2005]. "Gêneros Discursisvos" in Bakhtin: Conceitos-chave.. São Paulo: Contexto.

MAINGUENEAU, Dominique [2001]. Análise de textos de comunicação. São Paulo: Cortez.

MARCUSCHI, Luiz Antônio [1986]. Lingüística de texto: o que é e como se faz. Recife: Universidade Federal de Pernambuco.

MARTINS, Nilce Sant'Anna [2000]. Introdução à Estilística: a expressividade na língua portuguesa. São Paulo, T. A. Queiroz.

MICHELETTI, Guaraciaba [1997]. "Repetição e significado poético" in Filologia e Língua Portuguesa. São Paulo: Humanitas.

MIRA MATEUS, M. Helena et. Allii [1989]. "Mecanismos da estruturação textual" in Gramática da língua portuguesa. Lisboa: Caminho.

MOREIRA, Rosa e ULHÔA, Eliane [1996]. Assessoria de Imprensa: o papel do assessor. Brasília: FENAJ.

MOSCA, Lineide do Lago Salvador (org) [2001]. Retóricas de ontem e de hoje. São Paulo: Humanitas.

PÊCHEUX, Michel [1990]. "Análise Automática do Discurso" IN F. Gadet e T. Taks (orgs). Por uma análise do discurso automático. Campinas: UNICAMP.

PÊCHEUX, Michel [1988]. Semântica e Discurso. Campinas: UNICAMP.

PERELMAN, Ch [1984]. "Argumentação" IN Enciclopedia Einaudi. Lisboa: Imprensa Nacional-Casa da Moeda, vol. 11.

PERELMAN, Ch [1970]. Le champs de l'argumentation. Bruxelas: PUB.

ROCCO, Maria Thereza Fraga [1999]. Linguagem autoritária: televisão e persuasão. São Paulo: Brasiliense.

SCHNEUWLY, Bernard, DOLZ, Joaquim e colaboradores [2004]. Gêneros Orais e Escritos na Escola. Campinas: Mercado das Letras.

TYNIANOV, Yuri [1982]. "Os traços flutuantes de significação no verso" in O discurso da poesia, Poétique $\mathrm{n}^{\circ} 28$. Coimbra: Almedina.

VAN DIJK, Teun A [2000]. Cognição, discurso e interação. São Paulo: Contexto. 